\title{
FULL SCALE BIOREACTOR LANDFILL FOR CARBON \\ SEQUESTRATION AND GREENHOUSE EMISSION CONTROL
}

\section{Technical Progress Report}

Reporting Period Start Date: July 1, 2001

Reporting Period End Date: September 30, 2001

Principal Author(s)

Ramin Yazdani, Assistant Director, Yolo County Public Works, California

Jeff Kieffer, Associate Civil Engineer, Yolo County Public Works, California

Heather Akau, Junior Engineer, Yolo County Public Works, California

Date Report Issued

February 2002

DOE Award Number

DE-FC26-01NT41152, Task 7

Name and Address of Submitting Organization

Yolo County, Planning and Public Works Department

Attn: Ramin Yazdani

292 West Beamer Street

Woodland, CA 95695 


\section{DISCLAIMER}

This report was prepared as an account of work sponsored by an agency of the United States Government. Neither the United States Government nor any agency thereof, nor any of their employees, makes any warranty, express or implied, or assumes any legal liability or responsibility for the accuracy, completeness, or usefulness of any information, apparatus, product, or process disclosed, or represents that its use would not infringe privately owned rights. Reference herein to any specific commercial product, process, or service by trade name, trademark, manufacturer, or otherwise does not necessarily constitute or imply its endorsement, recommendation, or favoring by the United States Government or any agency thereof. The views and opinions of the authors expressed herein do not necessarily state or reflect those of the United States Government or any agency thereof. 


\section{ABSTRACT}

The Yolo County Department of Planning and Public Works is constructing a full-scale bioreactor landfill as a part of the Environmental Protection Agency's (EPA) Project XL program to develop innovative approaches while providing superior environmental protection. The overall objective is to manage landfill solid waste for rapid waste decomposition, maximum landfill gas generation and capture, and minimum long-term environmental consequences. Waste decomposition is accelerated by improving conditions for either the aerobic or anaerobic biological processes and involves circulating controlled quantities of liquid (leachate, groundwater, gray water, etc.), and, in the aerobic process, large volumes of air.

The first phase of the project entails the construction of a 12-acre module that contains a 6-acre anaerobic cell, a 3.5-acre anaerobic cell, and a 2.5-acre aerobic cell at the Yolo County Central Landfill near Davis, California. The cells are highly instrumented to monitor bioreactor performance. The current project status and preliminary monitoring results are summarized in this report. 


\section{DISCLAIMER}

\section{TABLE OF CONTENTS}

\section{ABSTRACT}

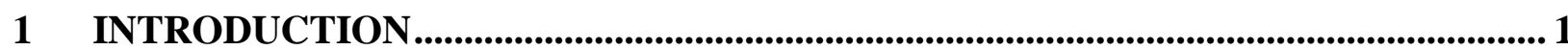

1.1 DESCRIPTION Of THE PROJECT AND ITS PURPoSE.......................................................... 1

1.2 DESCRIPTION Of THE FACILITY AND THE OPERATIONS / GEOGRAPHIC AREA …….............. 2

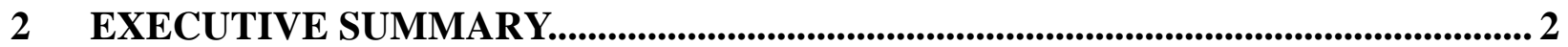

3 NORTHEAST ANAEROBIC CELL ........................................................................ 4

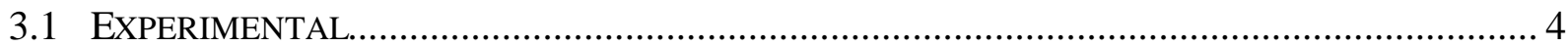

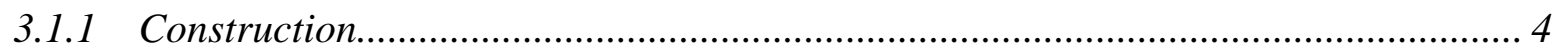

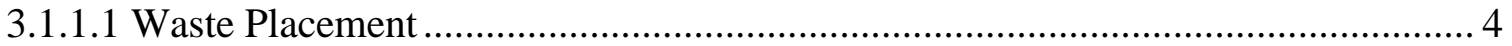

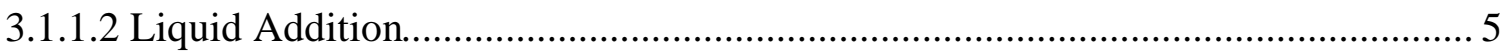

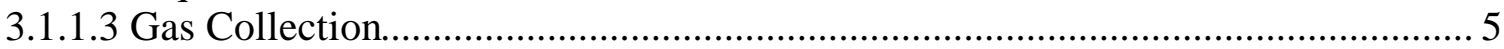

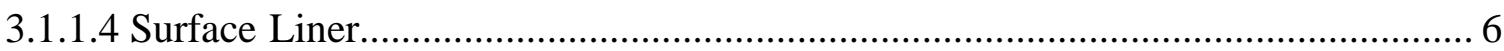

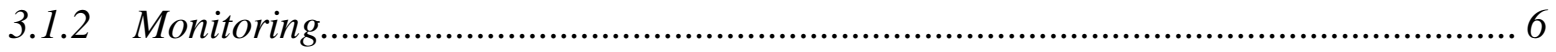

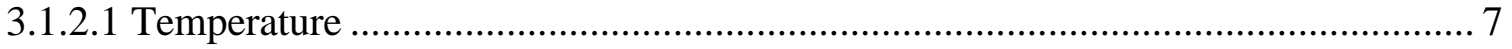

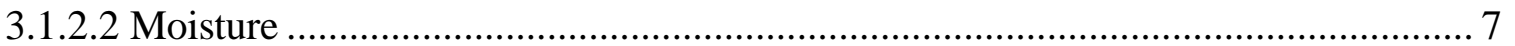

3.1.2.3 Leachate Quantity and Quality....................................................................... 7

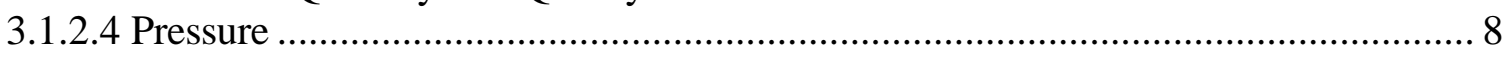

3.1.2.5 Landfill Gas Composition...................................................................... 8

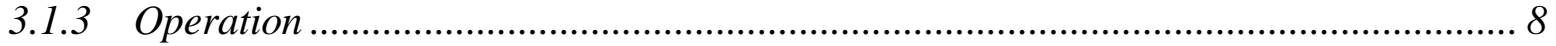

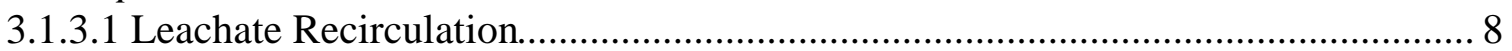

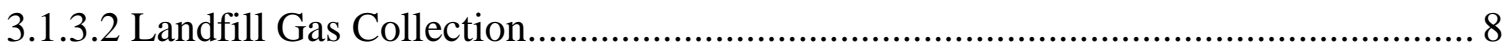

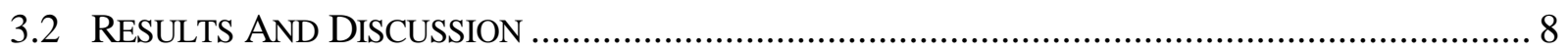

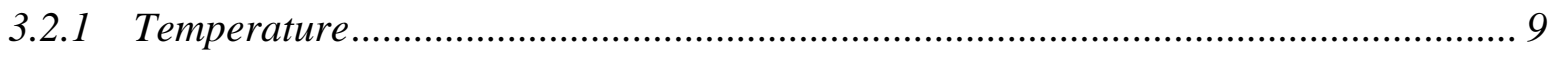

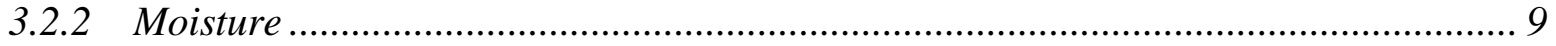

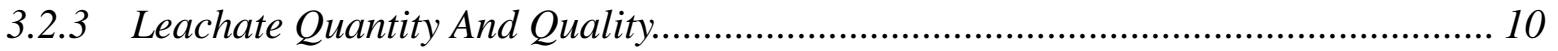

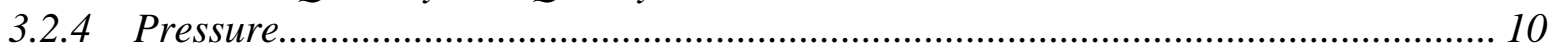

3.2.5 Landfill Gas Composition ................................................................................. 11

4 WEST-SIDE ANAEROBIC CELL ........................................................................................ 11

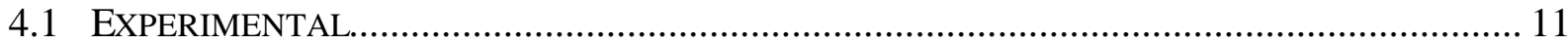

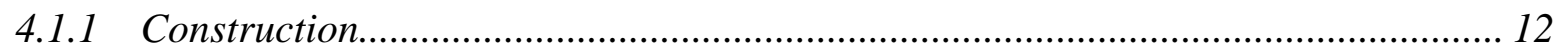

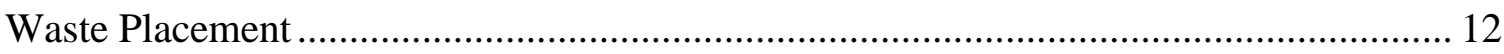

4.1.1.2 Liquid Addition............................................................................................ 12

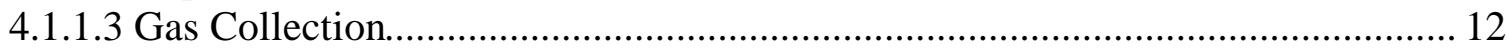

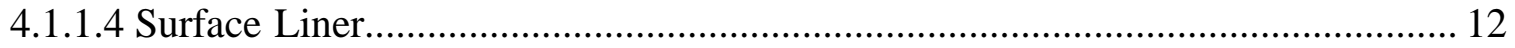

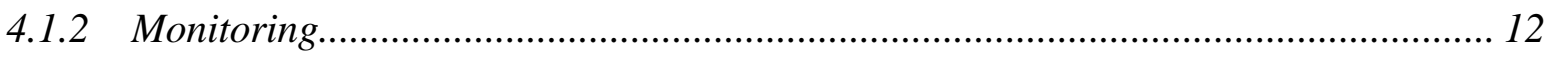

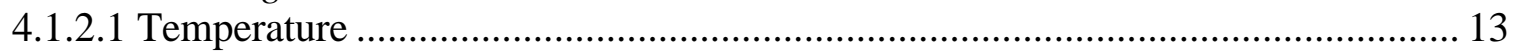

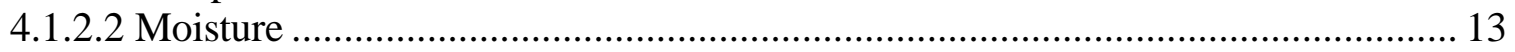

4.1.2.3 Leachate Quantity and Quality......................................................................... 13

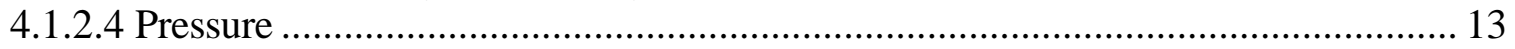

4.1.2.5 Landfill Gas Composition................................................................................ 13

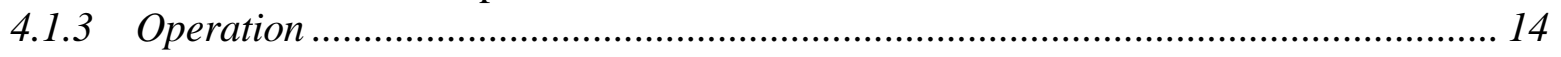

4.1.3.1 Leachate Recirculation............................................................................... 14 
4.1.3.2 Landfill Gas Collectio n............................................................................. 14

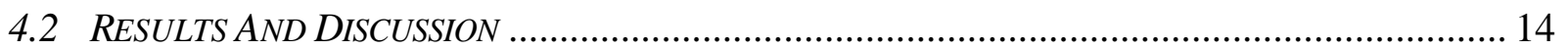

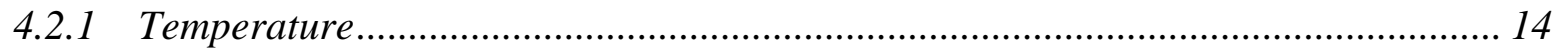

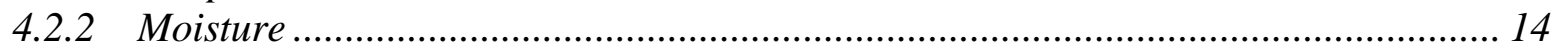

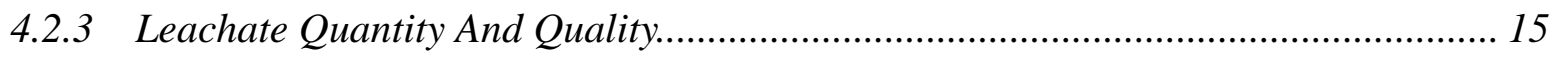

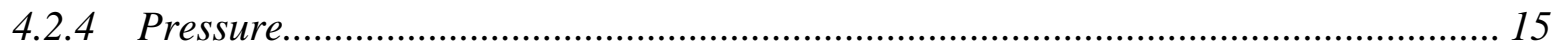

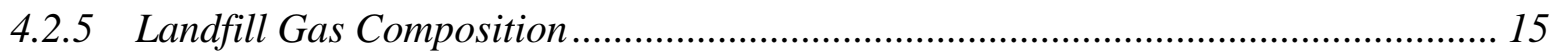

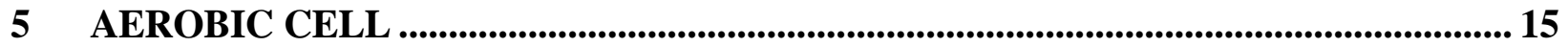

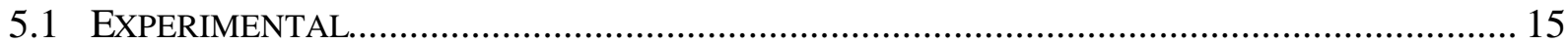

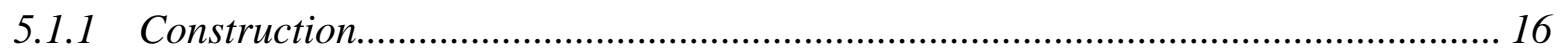

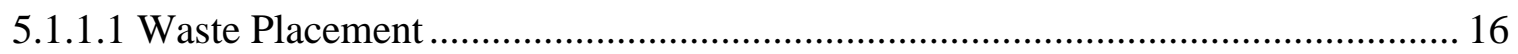

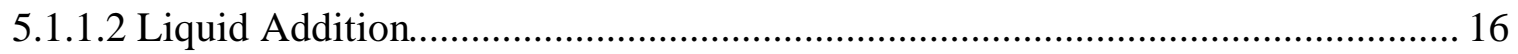

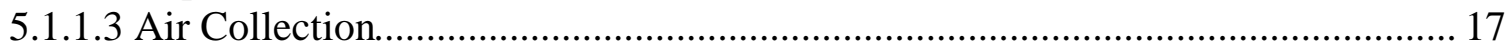

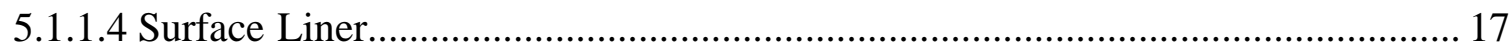

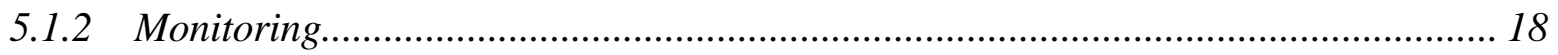

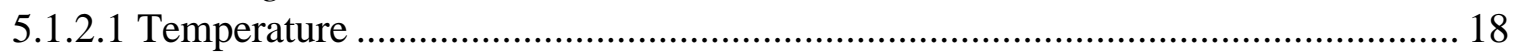

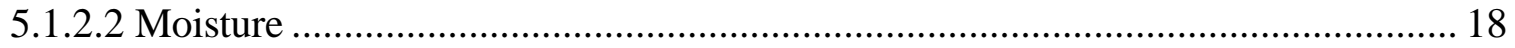

5.1.2.3 Leachate Quantity and Quality...................................................................... 19

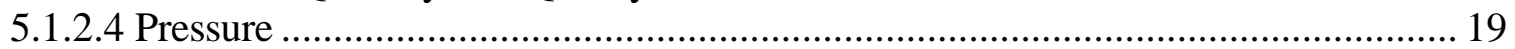

5.1.2.5 Landfill Gas Composition................................................................................. 19

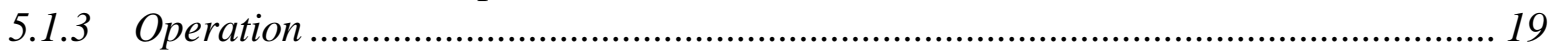

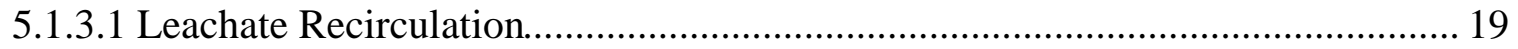

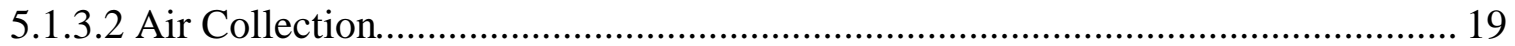

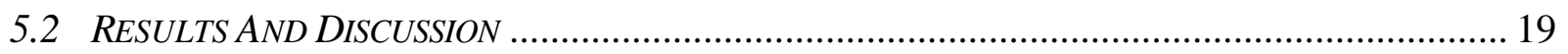

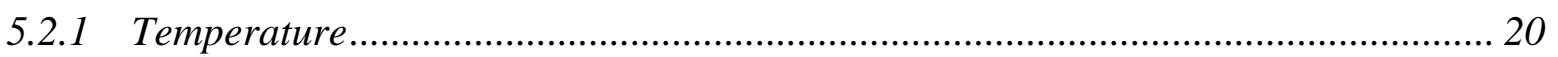

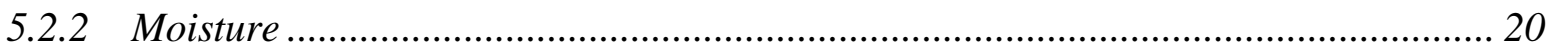

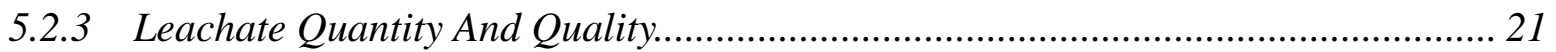

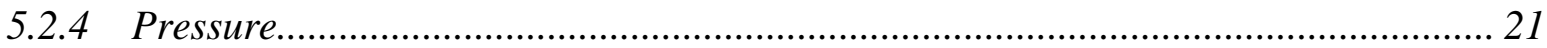

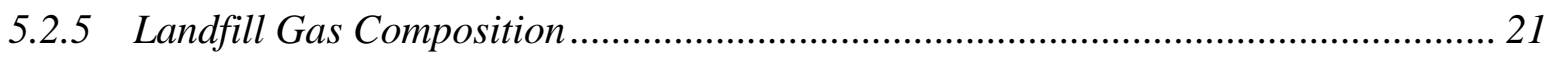

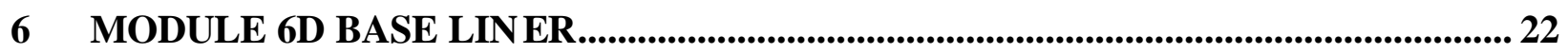

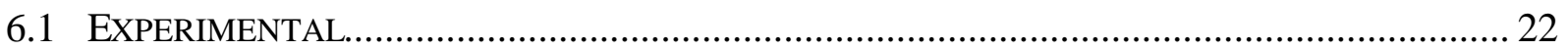

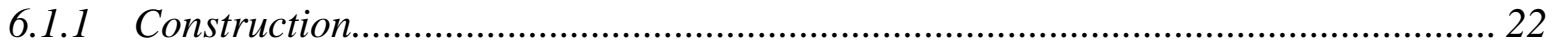

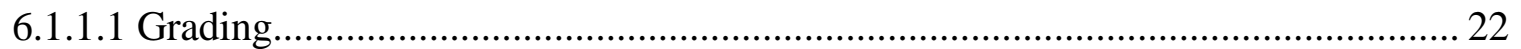

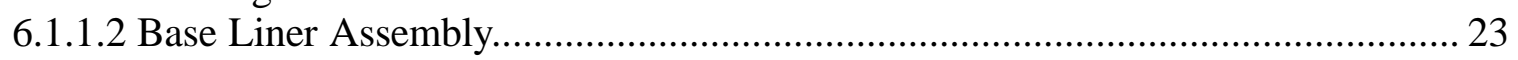

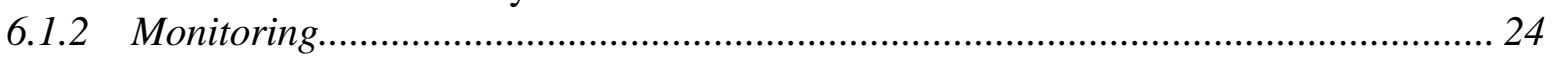

6.1.2.1 Leachate Collection Trenches …………………….......................................... 24

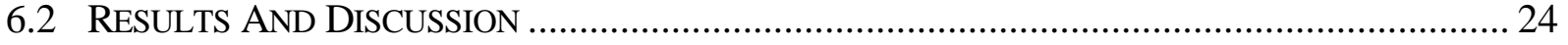

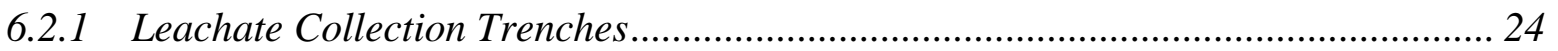

7 SUPERVISORY CONTROL AND DATA ACQUISITION SYSTEM .......................... 25

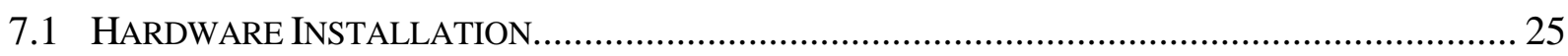

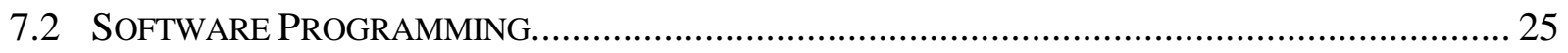

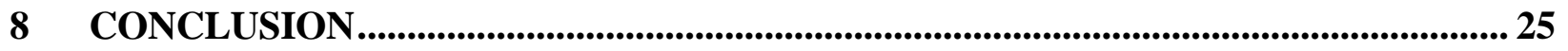

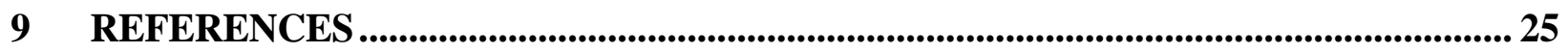

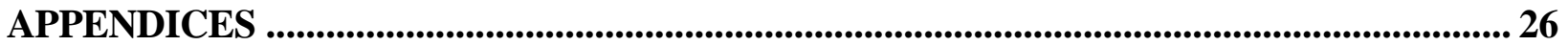




\section{INTRODUCTION}

Sanitary landfilling is the dominant method of solid waste disposal in the United States, accounting for about 217 million tons of waste annually (U.S. EPA, 1997). The annual production of municipal solid waste in the United States has more than doubled since 1960. In spite of increasing rates of reuse and recycling, population and economic growth will continue to render landfilling as an important and necessary component of solid waste management.

In a Bioreactor Landfill, controlled quantities of liquid (leachate, groundwater, grey-water, etc.) are added to increase the moisture content of the waste. Leachate is then recirculated as necessary to maintain the moisture content of the waste at or near it's moisture holding capacity. This process significantly increases the biodegradation rate of waste and thus decreases the waste stabilization and composting time (5 to 10 years) relative to what would occur within a conventional landfill (30 to 50 years or more). If the waste decomposes (i. e., is composted) in the absence of oxygen (anaerobically), it produces landfill gas (biogas). Biogas is primarily a mixture of methane, a potent greenhouse gas, carbon dioxide, and small amounts of Volatile Organic Compounds(VOC's). This by-product of anaerobic landfill waste composting can be a substantial renewable energy resource that can be recovered for electricity or other uses. Other benefits of a bioreactor landfill composting operation include increased landfill waste settlement and a resulting increase in landfill capacity and life, improved opportunities for treatment of leachate liquid that may drain from fractions of the waste, possible reduction of landfill postclosure management time and activities, landfill mining, and abatement of greenhouse gases through highly efficient methane capture over a much shorter period of time than is typical of waste management through conventional landfilling.

\section{$1.1 \quad$ DESCRIPTION OF THE PROJECT AND ITS PURPOSE}

The County of Yolo Planning and Public Works Department (Yolo County) is operating its next 20-acre landfill module near Davis, California as a controlled bioreactor landfill to attain a number of superior environmental and cost savings benefits. In the first phase of this 20 -acre project, a 12-acre module will be constructed. This 12-acre module contains a 6-acre cell and a 3.5-acre cell, which will be operated anaerobically, and a 2.5-acre cell, which will be operated aerobically. The County will construct the second phase of Module 6D in two years and depending on the results of the first phase of Module 6D, Yolo County may operate the second phase either anaerobically or aerobically.

Co-sponsors of the project with Yolo County are the Solid Waste Association of North America (SWANA) and Institute for Environmental Management (IEM, Inc.). As part of the FPA, Yolo County requested that U.S. EPA grant site-specific regulatory flexibility from the prohibition in 40 CFR 258.28 Liquid Restrictions, which may preclude addition of useful bulk or noncontainerized liquid amendments. The County intends to use leachate and groundwater first but if not enough liquid is available then other supplemental liquids such as gray-water from a waste water treatment plant, septic waste, and food-processing wastes will be used. Liquid wastes such as these, that normally have no beneficial use, may instead beneficially enhance the biodegradation of solid waste.

Yolo County also requested similar flexibility on liquid amendments from California and local regulatory entities. Several sections of the California Code of Regulations (CCR), Title 27, Environmental Protection, address the recirculation of liquids in lined municipal solid waste 
landfills. While the regulations do not specifically endorse bioreactors, regulatory flexibility is provided by the State of California Title 27, Chapter 3, Subchapter 2, Article 2, section 20200, Part (d)(3), Management of liquids at Landfills and Waste Piles. For additional information on this regulatory flexibility, see Section IV A of the FPA.

\subsection{DESCRIPTION OF THE FACILITY AND THE OPERATIONS / GEOGRAPHIC AREA} The Yolo County Central Landfill (YCCL) is an existing Class III non-hazardous municipal solid waste landfill. The site encompasses a total of 722 acres and is comprised of 17 distinct Class III solid waste management units and two Class II leachate surface impoundments. The YCCL is located at the intersection of Road 104 and Road 28H, 2 miles northeast of the City of Davis. The YCCL was opened in 1975 for the disposal of non-hazardous solid waste, construction debris, and non-hazardous liquid waste. Existing on-site operations include a thirteen-year-old landfill methane gas recovery and energy generation facility, a drop-off area for recyclables, a metal recovery facility, a wood and yard waste recovery and processing area, and a concrete recycling area.

There are approximately 28 residences scattered within a 2-mile radius of the landfill. The closest residence is located several hundred feet south of the landfill, on the south side of Road 29 south of the Willow Slough By-pass.

Groundwater levels at the facility fluctuate 8 to 10 feet during the year, rising from lowest in the Fall to highest in the Spring. Water level data indicate that the water table level is typically 4 to 10 feet below ground surface during winter and spring months. During summer and fall months, the water table is typically 5 to 15 feet below ground surface. In January 1989, the County of Yolo constructed a soil/bentonite slurry cutoff wall to retard groundwater flow to the landfill site from the north. The cutoff wall was constructed along portions of the northern and western boundaries of the site to a maximum depth of 44 feet. The cutoff wall has a total length of 3,680 feet, 2,880 feet along the north side and 800 feet along the west. In the fall of 1990, irrigation practices to the north of the landfill site were altered to minimize the infiltration of water.

Additionally, sixteen groundwater extraction wells were installed south of the cutoff wall in order to lower the water table south and east of the wall, to provide vertical separation between the base of the landfill and groundwater.

Prior to placement of the slurry wall and dewatering system, the groundwater flow direction was generally to the southeast. Under current dewatering conditions, the apparent groundwater flow paths are towards the extraction wells located along the western portion of the northern site boundary. In essence, a capture zone is created by the cone of depression created by the ground water extraction system, minimizing the possibility of off-site migration of contamination.

\section{EXECUTIVE SUMMARY}

This report provides an update on Phase 1 of the Yolo County Accelerated Anaerobic and Aerobic Composting (Bioreactor) Project. Phase 1 of the project encompasses a 12-acre area of a 20-acre landfill module (Unit 6, Module D) at the Yolo County Central Landfill. At this time, Phase 2 of the project is anticipated to begin in Fall 2002.

The bioreactor project continues on schedule without any major deviations. The project schedule is located in Appendix A, Table 1 and has been altered slightly since the previous project 
schedule prepared in January 2001. Liquid injection in the northeast anaerobic and the aerobic modules is now scheduled to begin in February 2002.

The configuration of the project bioreactor cells has been altered slightly from the original conceptual plan to provide for earlier data collection. Originally, the project entailed the construction of two bioreactor cells, one aerobic cell and one anaerobic cell. The original plan called for Module 6D, Phase 1, to be subdivided into four quadrants, with the aerobic bioreactor occupying 2.5 acres in the southeast quadrant, and the anaerobic cell forming a contiguous " $L$ " shape made up of the northwest, southwest, and northeast quadrants. The new configuration separates the northeast quadrant from the northwest and southwest quadrants, resulting in 3 separate landfill cells, two cells will be operated anaerobically and one aerobically (Detail 1). We have designated the three bioreactor cells as the west-side anaerobic cell, the northeast anaerobic cell, and the aerobic cell. This new configuration allows the northeast anaerobic cell to be constructed and operation of the bioreactor to begin prior to completion of the west-side anaerobic cell. By separating the anaerobic bioreactor into two separate cells, experiences gained from construction of the northeast cell can be incorporated into the west-side anaerobic cell.

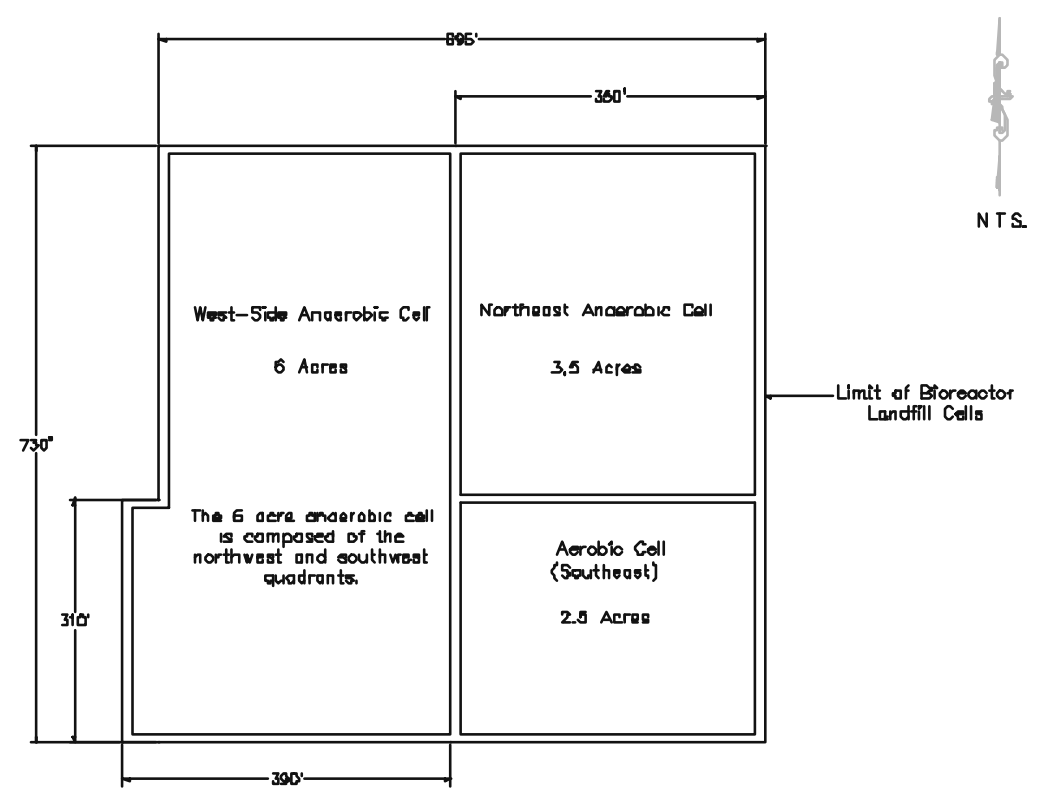

\section{Detail 1. Overview of Module D Bioreactor Cells}

The northeast anaerobic cell and the southeast aerobic cell have been filled with waste and the instrumentation, leachate injection, and gas collection systems have been installed. The westside anaerobic cell is still in the process of being filled with waste. Manual data collection is taking place for all instrumentation currently installed and as new instrumentation is installed, it is added to the monitoring program.

The installation of the surface membrane liner over the northeast anaerobic cell was completed in November 2001. Installation of a membrane cover over the southeast aerobic cell has been eliminated. The revised cover for the southeast aerobic cell will consist of 12-inches of soil covered by 12-inches of greenwaste alternative daily cover (ADC). The aerobic reaction will now be maintained by drawing air through the waste by a high vacuum capable blower. 
Drawing air through the cell will eliminate the difficulties associated with excessive pressure buildup under the liner and provide for more accurate gas composition measurements from the aerobic reaction.

All Supervisory Control and Data Acquisition (SCADA) hardware for the data collection system will be housed in a shed located at the southern limit of the bioreactor cells. The shed was installed in May 2001. All instrumentation leads will be extended from the bioreactor cells to the shed and connected to the SCADA system. An electrical consultant has been retained to design and install the electronic equipment and program the SCADA software that will be used to monitor the various sensors and control the operation of the bioreactor. The field electronics will be linked by radio signal to a computer located in our Woodland office.

Manual data collection is currently performed on a weekly basis prior to installation of the SCADA system.

The final EPA rule was published in the Federal Register on August 13, 2001. The approval of this rule allows for supplemental liquid (groundwater, gray water, septic waste, and food processing wastes) to be added to the bioreactor cells in addition to leachate.

\section{NORTHEAST ANAEROBIC CELL}

The northeast anaerobic cell occupies approximately 3.5 acres in the northeast quadrant of Phase 1, Module 6D.

\subsection{EXPERIMENTAL}

The experimental methods utilized are grouped into three categories: construction, monitoring, and operation. Each of these categories is discussed below.

\subsubsection{Construction}

Construction of the northeast anaerobic cell can be generally broken down into four major tasks: waste placement, liquid addition, gas collection, and surface liner installation. Each of these four tasks is discussed below. A summary of current monitoring data for the northeast anaerobic cell is provided in Appendix A, Table 2.

\subsubsection{Waste Placement}

Waste placement began on January 13, 2001 and was completed on August 3, 2001. Waste was placed in four separate lifts with an average thickness of 15 feet (Detail 2). In general, all waste received at the landfill was deposited in the northeast cell with the exception of self-haul waste. Because of the difficulties handling large volumes of self-haul vehicles in the limited area of the upper lifts, self-haul waste was not placed in lifts 3 and 4. The use of daily cover soil during waste filling was minimized to aid in the overall permeability of the waste. Whenever possible, greenwaste or tarps were used as alternative daily cover (ADC) and, in the event soil was placed (for example, access roads or tipping pad), the soil was removed prior to placing the next lift of waste. All side slopes were constructed at approximately 2.5 to 1 (horizontal to vertical) and received at least one foot of soil cover. Instrumentation Layers 1, 2, and 3 were placed between lifts, and base layer instrumentation was installed on the Module 6D base liner. A summary of sensors installed on each layer is provided in Appendix A, Table 3. 


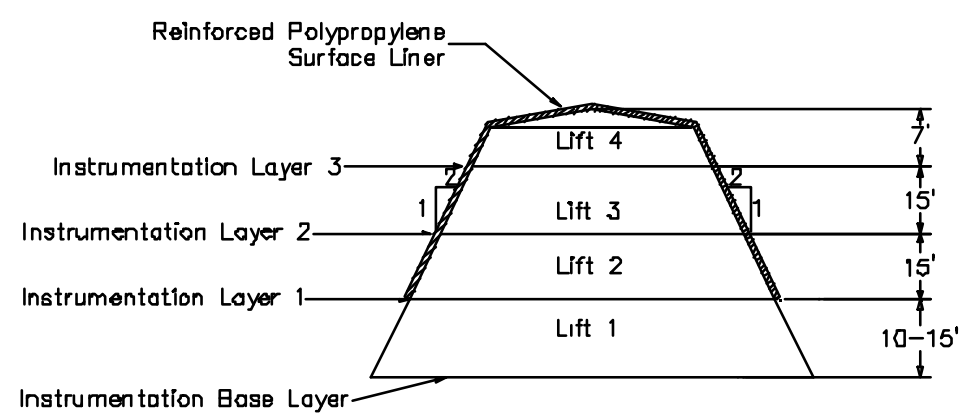

\section{Detail 2. Northeast Anaerobic Cell Cross Section}

\subsubsection{Liquid Addition}

Horizontal liquid injection lines were installed in each lift of waste. Injection lines within the waste (between lifts 1 and 2, 2 and 3, 3 and 4) were placed at approximately 40-foot spacing. Injection lines installed on top of lift 4 were installed at approximately 25 -foot spacing with an additional injection line following the perimeter of the top deck. Each injection line consists of a 1.25-inch-diameter high-density polyethylene (HDPE) pipe placed horizontally (north to south), which extends completely through the waste. Each injection line was perforated by drilling a $3 / 32$-inch hole every 20 feet. A total of 8,130 feet of injection piping was installed with a total of 342 injection holes.

Each of the injection laterals will be connected to a 4-inch-diameter HDPE injection header. Flow rate and pressure will be monitored at each injection lateral. Leachate injection for each lateral will be monitored and controlled by individual solenoid valves connected to the SCADA system. A second, redundant flow meter will monitor the total volume and injection flow rate for the entire northeast anaerobic cell.

Leachate recirculation and bioreactor operation of the northeast cell is anticipated to begin in February 2002.

\subsubsection{Gas Collection}

Horizontal landfill gas (LFG) collection lines were installed between each lift of waste and directly under the reinforced polypropylene (RPP) geomembrane cover. LFG collection lines consist of various combinations of alternating 4 and 6-inch-diameter, schedule 80 polyvinyl chloride (PVC) pipe as well as several variations using corrugated HDPE pipe. A summary of gas collection lines for the northeast anaerobic cell is provided in Appendix A, Table 4. At each line, shredded tires were used as the permeable media. The gas collection lines between layers are spaced approximately 40 feet apart and the lines directly under the RPP membrane are spaced at 25 feet. A total of sixteen LFG collection lines were installed.

Each LFG collection line is connected to a 6-inch-diameter LFG collection header that will convey the gas to the on-site LFG-to-energy facility. Each LFG collection line will incorporate a pre-manufactured wellhead capable of controlling flow and monitoring flow rate, temperature and pressure. 


\subsubsection{Surface Liner}

The County retained the services of Vector Engineering (Vector) to design the surface membrane covers for each of the bioreactor cells. Their scope of work included the following subtasks:

- Research the different commercially available membrane materials, including high and low density polyethylene, polyvinyl chloride, and reinforced polypropylene;

- Design of a biofilter to treat the off-gas from the aerobic cell;

- Prepare plans and specification for the installation of the surface liners; and

- Provide on-site construction quality assurance for the installation of the surface membrane.

Vector's scope of work was modified to include preparation of plans and specifications for the tie-in of the leachate injection and landfill gas collection piping.

Based on Vector and County staff research, it was determined that a 36-mil reinforced polypropylene geomembrane (RPP) would be the preferred choice for an exposed geomembrane cover ${ }^{1}$. Reinforced polypropylene offered distinct advantages over the other potential materials including long service life (a 20-year warrantee was obtained), superior strength due to the nylon reinforcement, and low thermal expansion and contraction.

To expedite construction and reduce the overall cost of the project, the County decided to directly purchase the necessary membrane material and provide it to the contractor for installation. On June 29, 2001, the County issued a request for quotes for 350,000 square feet of 36-mil RPP. Quotes were received on July 9, 2001 with the lowest priced quote received from Colorado Linings International (Colorado).

The plans and specifications for the installation of the RPP surface liner were issued for bid on June 15, 2001. Later that month, Addendum Number 1 was issued to include a majority of the leachate injection and gas collection piping. Bids were due on July 13, 2001; however, no bids were received. The County inquired to each of the plan holders and generally found that bids were not submitted because the liner companies could not locate a subcontractor to perform the earthwork.

The County reissued the plans and specifications on July 23, 2001 and allowed three separate bid options. Option A was the entire project. Option B was only the installation of the liner, and Option C was only the earthwork. Bids were received on August 6, 2001 with the selected contractor being Colorado Linings International. Because Colorado's winning bid was significantly higher than the engineer's estimate and the potential difficulties with excessive pressure buildup under the aerobic liner, the covering of the aerobic cell was eliminated (for further discussion refer to Section 5.1).

The installation of surface liner and associated piping was completed in November 2001.

\subsubsection{Monitoring}

Temperature, moisture, leachate quantity and quality, and LFG pressure and composition are monitored through an array of sensors placed within the waste and in the leachate collection and

\footnotetext{
${ }^{1}$ Vector Engineering, "Design Report for the Surface Liners of the Module D Phase 1 Bioreactors at the Yolo County Central Landfill", October 2001.
} 
recovery system (LCRS). Each sensor location on the base layer received a temperature sensor (thermistor), a linear low-density polyethylene (LLDPE) tube, and selected locations received a PVC moisture sensor. Each sensor location within the waste received a temperature sensor (thermistor), a linear low-density polyethylene (LLDPE) tube, and a moisture sensor (a PVC moisture sensor and in some cases a gypsum block). For protection, each wire and tube was encased in either a 1.25-inch HDPE pipe or run inside the LFG collection piping. Refer to Appendix B, Details 7 through 10 for sensor location diagrams.

Sensors on instrumentation Layers 1, 2, and 3 were placed on either a bedding of greenwaste (shredded yard waste), wood chips (chipped wood waste), bin fines (fine pieces of greenwaste), or pea gravel to protect against damage from the underlying waste. Sensors installed on the primary liner (prior to any waste placement) were placed on geocomposite and covered with pea gravel prior to the placement of the chipped tire operations layer.

\subsubsection{Temperature}

Temperature is monitored with thermistors manufactured by Quality Thermistor, Inc. Thermistors with a temperature range of $0^{\circ} \mathrm{C}$ to $100^{\circ} \mathrm{C}$ were chosen to accommodate the temperature ranges expected in both the anaerobic and aerobic cells. To prevent corrosion, each thermistor was encased in epoxy and set in a stainless steel sleeve. All field wiring connections were made by first soldering the connection, then covering each solder joint with adhesive lined heat shrink tubing, and then encasing the joint in electrical epoxy. Changes in temperature are measured by the change in thermistor resistivity (ohms). As temperature increases, thermistor resistance decreases.

\subsubsection{Moisture}

Moisture levels are measured with polyvinyl chloride (PVC) moisture sensors and gypsum blocks. Both the PVC moisture sensors and gypsum blocks are read utilizing the same meter. The PVC sensors are perforated 2-inch-diameter PVC pipes with two stainless steel screws spaced 8 inches apart and attached to wires to form a circuit that includes the gravel filled pipe. The PVC sensors were designed by Yolo County and used successfully during the pilot scale project $^{2}$. The PVC moisture sensor can provide a general, qualitative assessment of the waste's moisture content. A reading of 0 to 40 equates to no free liquid, 40 to 80 equates to some free liquid, and 80 to 100 means completely saturated conditions.

The gypsum blocks are manufactured by Electronics Unlimited and are typically used for soil moisture determinations in agricultural applications. Gypsum blocks establish equilibrium with the media in which they are placed and are, therefore, reliable at tracking increases in the soil's moisture content. However, the gypsum block can take considerable time to dry and therefore may not reflect the drying of the surrounding environment.

\subsubsection{Leachate Quantity and Quality}

Leachate that is generated from the northeast anaerobic cell drains to the eastside Module D leachate collection sump. A dedicated pump is then used to remove the leachate and pump it to

\footnotetext{
${ }^{2}$ Yazdani, R., Moore, R. Dahl. K. and D. Augenstein 1998 Yolo County Controlled Landfill Bioreactor Project. Yolo County Public Works and I E M, Inc. Yolo County Public Works and I E M, Inc. report to the Urban Consortium Energy Foundation (UUCETF) and the Western Regional Biomass Energy Program, USDOE.
} 
one of the on-site leachate storage ponds. A flow meter measures rate and total volume pumped from the sump.

Leachate is monitored for the following field parameters: $\mathrm{pH}$, electrical conductivity, dissolved oxygen, oxidation-reduction potential, and temperature. When leachate is generated in sufficient quantities, the following parameters will be analyzed by a laboratory: dissolved solids, biochemical oxygen demand, chemical oxygen demand, organic carbon, nutrients $\left(\mathrm{NH}_{3}, \mathrm{TKN}\right.$, $\mathrm{TP}$ ), common ions, heavy metals and organic priority pollutants. For the first year, monitoring will be conducted monthly during the first six months and quarterly for the following six months. After the first year, monitoring will be conducted semi-annually $(\mathrm{pH}$, conductivity, and flow rate will continue to be monitored on a monthly basis as required by the State of California's Waste Discharge Requirements in Order 5-00-134).

\subsubsection{Pressure}

Pressure within the northeast anaerobic cell is monitored with $1 / 4$-inch inner diameter and $3 / 8$-inch outer diameter LLDPE sampling tubes. Each tube can be attached to a pressure gage and supplemental air source. By first purging the tube with the air source (to remove any liquid blockages), and then reading the pressure, an accurate gas and/or water pressure can be measured at each sensor location.

\subsubsection{Landfill Gas Composition}

Gas composition is measured utilizing a GEM-500 combustible gas meter, manufactured by LANDTEC. The GEM-500 is capable of measuring methane (either as a percent by volume or percent of the lower explosive limit), carbon dioxide, and oxygen. A reading for "balance" gas is also provided, which is assumed to be nitrogen. Currently, gas composition is analyzed from the same sampling tubes used to measure pressure.

\subsubsection{Operation}

Operation of the northeast anaerobic cell as a bioreactor will begin once the surface liner, LFG collection system, leachate recirculation systems, and SCADA control systems are complete. At this time, we anticipate bioreactor operation to begin in February 2002.

\subsubsection{Leachate Recirculation}

Initially, large volumes of liquid will be added to bring the waste to field capacity. Once field capacity has been reached, only enough liquid to maintain field capacity will be added.

\subsubsection{Landfill Gas Collection}

Landfill gas collection began December 13, 2001 once the necessary piping was installed at the end of November 2001. Gas collection prior to leachate recirculation will be necessary to prevent "billowing" or excess gas pressure under the surface liner.

\subsection{RESULTS AND DISCUSSION}

Sensor names are represented numerically by the instrumentation layer in which the sensor is located, followed by the assigned sensor number. The base layer is represented by a 0 , Layer 1 is represented by a 1 , and so forth. The complete name of the sensor is denoted by the layer number - the sensor number. For example, the second sensor on Layer 1 is named 1-02. 


\subsubsection{Temperature}

Temperature is monitored with thermistors manufactured by Quality Thermistor, Inc. Thermistors with a temperature range of $0^{\circ} \mathrm{C}$ to $100^{\circ} \mathrm{C}$ were chosen so they would be able to accommodate the temperature ranges expected in both the anaerobic and aerobic cells. Currently, resistance is measured manually by connecting the sensor wires to a 26 III Multimeter manufactured by Fluke Corporation.

\section{Base Layer}

The northeast base layer temperatures have steadily increased and converged between $68^{\circ} \mathrm{F}$ and $77^{\circ} \mathrm{F}\left(20^{\circ} \mathrm{C}\right.$ and $\left.25^{\circ} \mathrm{C}\right)$ as presented in Appendix $\mathrm{C}$, Figure 1.

\section{Layer 1}

High temperatures ranging between approximately 97 to $122^{\circ} \mathrm{F}\left(36^{\circ} \mathrm{C}\right.$ to $\left.50^{\circ} \mathrm{C}\right)$ are being recorded on Layer 1 as presented in Appendix C, Figure 2. The higher temperatures in Layer 1 can be attributed to the ability of the base layer to act as a heat sink and dissipate energy to the cooler, surrounding soil.

\section{Layer 2}

The elevated temperatures, between approximately $126{ }^{\circ} \mathrm{F}$ and $155^{\circ} \mathrm{F}\left(52^{\circ} \mathrm{C}\right.$ and $\left.68^{\circ} \mathrm{C}\right)$, in Layer 2 appear to correspond to the beginning of the use of "bin fines" as the media surrounding the sensors and daily cover material (Appendix C, Figure 3). Wood chips were used on Layer 1 to cover the sensors, however, due to the low supply of this material, bin fines were used to cover the sensors on Layer 2. Bin fines seem to be a more readily biodegradable material than wood chips, as evidenced by the higher temperatures.

\section{Layer 3}

Temperature readings for Layer 3 are steady and generally range between $119^{\circ} \mathrm{F}$ and $149{ }^{\circ} \mathrm{F}$ $\left(48\right.$ and $65^{\circ} \mathrm{C}$ ) as presented in Appendix C, Figure 4. Bin fines were also used as the media surrounding the sensors and daily cover material.

\subsubsection{Moisture}

Moisture is measured with a Model MM 4 moisture meter manufactured by Electronics Unlimited. Moisture data are unitless numbers that give a qualitative assessment rather than a quantitative measure. During the pilot scale project, Yolo County conducted laboratory tests with the PVC sensors to determine the relationship between the multimeter readings and the presence of free liquid in the PVC sensor. It was determined that a meter reading of less than 40 corresponded to an absence of free liquid. A reading between 40 and 80 corresponds to the presence of free liquid in the PVC pipe but less than saturated conditions. Readings of greater than 80 indicate saturated conditions; i.e. the PVC sensor is full of liquid.

Base Layer

PVC moisture levels for the base layer are presented in Appendix C, Figure 5. Moisture levels have generally remained steady, ranging from approximately 7 to 13 , which equates to the no-free-liquid zone. 
Layer 1

PVC moisture levels for Layer 1 are presented in Appendix C, Figure 6. The moisture levels for this layer generally range between 0 and 18 in the no-free-liquid zone. Sensors 1-05 and 1-16 indicate higher moisture levels that equate to the some-free-liquid zone.

Layer 2

PVC moisture readings generally lie in the no-free-liquid zone ranging between 30 and 38 (Appendix C, Figure 7). PVC moisture sensor 2-12 and gypsum moisture sensor 2-12 initially indicated high levels of moisture in the some-free-liquid zone (Appendix C, Figure 8). However, PVC moisture sensor 2-12 shows a decline in moisture not reflected by gypsum sensor 2-12. High moisture readings from gypsum sensors 2-06, 2-08, 2-10, 2-11 and 2-15 do not correspond to PVC moisture sensor readings in the no-free-liquid zone. Gypsum sensors 2-04 and 2-10 exhibited high initial moisture readings, due to the plaster encasing the gypsum block not being fully dry before installation. High initial moisture readings from sensors 2-06, 2-11, and 2-12 are most likely a result of being wetted shortly after installation.

\section{Layer 3}

With the exception of sensors 3-04 and 3-05, Layer 3 moisture readings generally remain steady in the no-free-liquid zone. Sensor 3-04 moisture readings lie in the some-free-liquid zone and sensor 3-05 moisture shows a decline in moisture levels to the no-free-liquid zone (Appendix C, Figure 9).

\subsubsection{Leachate Quantity And Quality}

Prior to mid-February 2001, leachate data reflects rainfall rather than actual leachate generation because the cells were only partially filled, and portions of the leachate collection and removal system were exposed to rainfall.

Leachate chemistry is not reported because samples taken during the wet season were rainfall rather than leachate and low leachate levels following the rainy season did not allow collection of fresh leachate samples.

\subsubsection{Pressure}

Pressure measurements are taken from sampling tubes with a DWYER Instruments, Inc., "Magnehelic" pressure gage. Pressure measurements can be either positive or negative, although a vacuum has not yet been applied to the gas extraction lines, so negative pressures are not expected at this time. Positive pressures can result from both the generation of landfill gas and saturated liquid conditions.

\section{Base Layer}

Pressure readings from the northeast base layer pressure tubes are currently positive and below 1.02 centimeters of water ( 0.4 inches of water) as presented in Appendix C, Figure 10.

Layer 1

Pressure readings in Layer 1 are positive and remain below 2.49 centimeters of water (0.98 inches of water) as presented in Appendix C, Figure 11. 
Layer 2

Pressure readings in Layer 2 are positive and remain below 0.05 centimeters of water (0.02 inches of water) as presented in Appendix C, Figure 12.

Layer 3

Pressure readings in Layer 3 are positive and remain below 0.15 centimeters of water (0.06 inches of water) as presented in Appendix C, Figure 13.

\subsubsection{Landfill Gas Composition}

Gas composition is measured from sampling tubes on each layer of the cells with the GEM-500. Because liquid will damage the GEM, pressurized air is first forced through the tubes to remove any liquid, then the tube lines are purged with a vacuum pump and hooked up to the GEM to analyze the gas composition.

\section{Base Layer}

Data presented in Appendix C, Table 8, indicates high methane and carbon dioxide levels and depleted oxygen levels. Oxygen measured in the base layer is most likely the result of air intrusion into the permeable shredded tire operations layer (which was not completely covered by waste) that covers the entire bottom of Module 6D.

\section{Layer 1}

Layer 1 in the northeast quadrant is entering the anaerobic phase as presented in Appendix C, Table 9. Methane levels are increasing, carbon dioxide levels are decreasing, and oxygen has been depleted. Some of the oxygen concentrations measured from tubes 1-01, 1-02, 1-05, and 1-09 may have been the result of leaks during sampling.

\section{Layer 2}

Gas compositions from Layer 2 indicate decreasing oxygen levels and rising carbon dioxide levels as presented in Appendix C, Table 10. Insufficient data exists to draw definitive conclusions regarding this layer.

\section{Layer 3}

Gas compositions from Layer 3 indicate decreasing oxygen and carbon dioxide levels as presented in Appendix C, Table 11.

\section{WEST-SIDE ANAEROBIC CELL}

The west-side anaerobic cell is located on the western 6 acres of Phase 1, Module D. Filling in the west-side anaerobic cell is continuing with instrumentation, leachate injection and gas collection equipment being installed as filling proceeds.

\subsection{EXPERIMENTAL}

The experimental methods utilized are grouped into three categories: construction, monitoring, and operation. Each of these categories is discussed below. 


\subsubsection{Construction}

Construction of the west-side anaerobic cell can be generally broken down into four major tasks: waste placement, liquid addition, gas collection, and surface liner installation. Each of these four tasks is discussed below.

\subsubsection{Waste Placement}

In the west-side anaerobic cell, waste will be placed in four lifts of approximately 15 -foot thickness with 2.5:1 side slopes on interior slopes and 3:1 on exterior slopes (Detail 3). Waste placement for lifts 1 and 2 is currently taking place. A summary of sensors installed on the base layer is shown in Appendix A, Table 3.

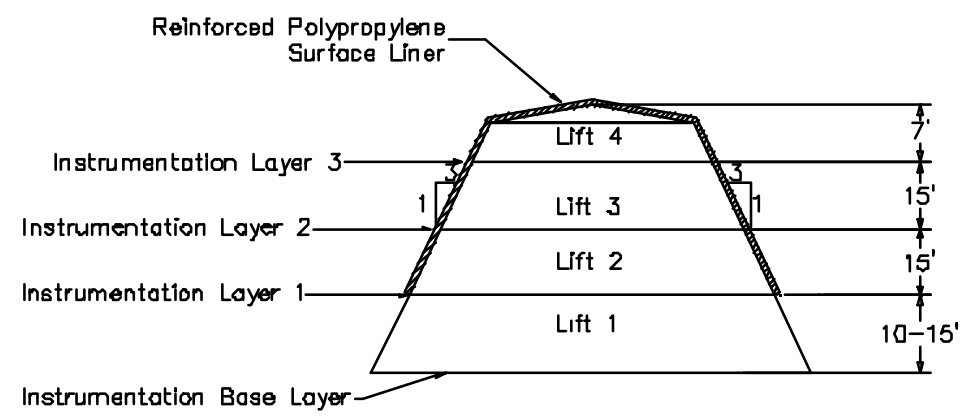

\section{Detail 3. Cross Section of West-Side Anaerobic}

\subsubsection{Liquid Addition}

Liquid addition piping has not yet been installed in the west-side anaerobic cell. Leachate injection piping will be installed between lifts 2 and 3 and on top of lift 4 .

\subsubsection{Gas Collection}

Gas collection piping has not yet been installed in the west-side anaerobic cell. Gas collection piping will be installed between lifts 2 and 3 and on top of lift 4 .

\subsubsection{Surface Liner}

A consultant was retained to provide design, plans and specifications for the surface lining systems. The west-side anaerobic cell is scheduled to be covered during the summer of 2002.

\subsubsection{Monitoring}

Temperature, moisture, leachate quantity and quality, and LFG pressure and composition are monitored through an array of sensors placed within the waste and in the leachate collection and recovery system (LCRS). Each sensor location on the base layer received a temperature sensor (thermistor), a linear low-density polyethylene (LLDPE) tube, and selected locations received a PVC moisture sensor. For protection, each wire and tube was encased in a PVC pipe. Refer to Appendix B, Detail 7 for a diagram of base layer sensor locations.

Sensors installed on the primary liner (prior to any waste placement) were placed on geocomposite and covered with pea gravel prior to the placement of the chipped tire operations layer. 


\subsubsection{Temperature}

Temperature is monitored with thermistors manufactured by Quality Thermistor, Inc. Thermistors with a temperature range of $0^{\circ} \mathrm{C}$ to $100^{\circ} \mathrm{C}$ were chosen to accommodate the temperature ranges expected in both the anaerobic and aerobic cells. To prevent corrosion, each thermistor was encased in epoxy and set in a stainless steel sleeve. All field wiring connections were made by first soldering the connection, then covering each solder joint with adhesive-lined heat shrink tubing, and then encasing the joint in electrical epoxy. Changes in temperature are measured by the change in thermistor resistivity (ohms). As temperature increases, thermistor resistance decreases.

\subsubsection{Moisture}

Moisture levels are measured with polyvinyl chloride (PVC) moisture sensors and gypsum blocks. Both the PVC moisture sensors and gypsum blocks are read utilizing the same meter. The PVC sensors are perforated 2-inch-diameter PVC pipes with two stainless steel screws spaced 8 inches apart and attached to wires to form a circuit that includes the gravel filled pipe. The PVC sensors were designed by Yolo County and used successfully during the pilot scale project. The PVC moisture sensor can provide a general, qualitative assessment of the waste's moisture content. A reading of 0 to 40 equates to no free liquid, 40 to 80 equates to some free liquid, and 80 to 100 means completely saturated conditions.

\subsubsection{Leachate Quantity and Quality}

Leachate that is generated from the west-side anaerobic cell drains to the west-side Module D leachate collection sump. A dedicated pump is then used to remove the leachate and pump it to one of the on-site leachate storage ponds. A flow meter measures rate and total volume pumped from the sump.

Leachate is monitored for the following field parameters: $\mathrm{pH}$, electrical conductivity, dissolved oxygen, oxidation-reduction potential, and temperature. When leachate is generated in sufficient quantities, the following parameters will be analyzed by a laboratory: dissolved solids, biochemical oxygen demand, chemical oxygen demand, organic carbon, nutrients $\left(\mathrm{NH}_{3}, \mathrm{TKN}\right.$, $\mathrm{TP}$ ), common ions, heavy metals and organic priority pollutants. For the first year, monitoring will be conducted monthly for the first six months and quarterly for the following six months. After the first year, monitoring will be conducted semi-annually $(\mathrm{pH}$, conductivity, and flow rate will continue to be monitored on a monthly basis as required by the State of California's Waste Discharge Requirements in Order 5-00-134).

\subsubsection{Pressure}

Pressure within the northeast anaerobic cell is monitored with $1 / 4$-inch inner diameter and $3 / 8$-inch outer diameter LLDPE sampling tubes. Each tube can be attached to a pressure gage and supplemental air source. By first purging the tube with the air source (to remove any liquid blockages) and then reading the pressure, an accurate gas and/or water pressure can be measured at each sensor location.

\subsubsection{Landfill Gas Composition}

Gas composition is measured utilizing a GEM-500 combustible gas meter manufactured by LANDTEC. The GEM-500 is capable of measuring methane (either as a percent by volume or percent of the lower explosive limit), carbon dioxide, and oxygen. A reading for "balance" gas 
is also provided, which is assumed to be nitrogen. Currently, gas composition is analyzed from the same sampling tubes used to measure pressure.

\subsubsection{Operation}

Operation of the west-side anaerobic cell will begin once waste placement, sensor installation, landfill gas (LFG) collection system, leachate recirculation systems, and SCADA control systems are complete.

\subsubsection{Leachate Recirculation}

Initially, large volumes of liquid will be added to bring the waste to field capacity. Once field capacity has been reached, only enough liquid to maintain field capacity will be added.

\subsubsection{Landfill Gas Collection}

Landfill gas collection will begin as soon as waste placement is completed and the necessary piping installed.

\subsection{Results And Discussion}

Sensor names are represented numerically by the instrumentation layer in which the sensor is located and by the assigned sensor number for that layer. The base layer is represented by a 0 , Layer 1 is represented by a 1, and so forth. The complete name of the sensor is denoted by the layer number - the sensor number. For example, the second sensor on Layer 1 is named 1-02.

\subsubsection{Temperature}

Temperature is monitored with thermistors manufactured by Quality Thermistor, Inc. Thermistors with a temperature range of $0^{\circ} \mathrm{C}$ to $100^{\circ} \mathrm{C}$ were chosen so they would be able to accommodate the temperature ranges expected in both the anaerobic and aerobic cells. Currently, resistance is measured manually by connecting the sensor lines to a 26 III Multimeter manufactured by Fluke Corporation.

\section{Base Layer}

Southwest base layer temperatures are beginning to converge and range between approximately $73{ }^{\circ} \mathrm{F}$ and $100{ }^{\circ} \mathrm{F}\left(23{ }^{\circ} \mathrm{C}\right.$ and $\left.38^{\circ} \mathrm{C}\right)$ as presented in Appendix C, Figure 14.

Northwest base layer temperatures are beginning to converge and range between approximately $75^{\circ} \mathrm{F}$ and $93{ }^{\circ} \mathrm{F}\left(24^{\circ} \mathrm{C}\right.$ and $\left.34^{\circ} \mathrm{C}\right)$ as presented in Appendix C, Figure 15.

\subsubsection{Moisture}

Moisture is measured with a Model MM 4 moisture meter manufactured by Electronics Unlimited. Moisture data are unitless numbers that give a qualitative assessment rather than a quantitative measure. During the pilot scale project, Yolo County conducted laboratory tests with the PVC sensors to determine the relationship between the multimeter readings and the presence of free liquid in the PVC sensor. It was determined that a meter reading of less than 40 corresponded to an absence of free liquid. A reading between 40 and 80 corresponds to the presence of free liquid in the PVC pipe but less than saturated conditions. Readings of greater than 80 indicate saturated conditions; i.e. the PVC sensor is full of liquid. 
Base Layer

PVC moisture levels for the base layer are presented in Appendix C, Figure 16. Moisture levels range from approximately 0 to 5 indicating no free liquid.

\subsubsection{Leachate Quantity And Quality}

Prior October 2001, leachate data reflects rainfall rather than actual leachate generation because the cell was only partially filled, and portions of the leachate collection and removal system were exposed to rainfall.

Leachate chemistry is not reported because samples taken during the wet season were rainfall rather than leachate and low leachate levels following the rainy season did not allow collection of fresh leachate samples.

\subsubsection{Pressure}

Pressure measurements are taken from sampling tubes with a DWYER Instruments, Inc., "Magnehelic" pressure gage. Pressure measurements can be either positive or negative, although a vacuum has not yet been applied to the gas extraction lines, so negative pressures are not expected at this time. Positive pressures can result from both the generation of landfill gas and saturated liquid conditions.

\section{Base Layer}

Pressure readings from the west-side anaerobic cell are currently positive and range between 0.15 and 1.02 centimeters of water ( 0.06 and 0.4 inches of water) as presented in Appendix C, Figures 17 and 18.

\subsubsection{Landfill Gas Composition}

Gas composition is measured from sampling tubes on each layer of the cells with the GEM-500. Because liquid will damage the GEM, pressurized air is first forced through the tubes and liquid is pushed out, then the tube lines are purged with a vacuum pump and hooked up to the GEM to analyze the gas composition.

\section{Base Layer}

Only sensors locations that have been covered by waste have been monitored for gas composition. Data presented in Appendix C, Table 12 indicates increasing methane and carbon dioxide levels and decreasing oxygen levels. Oxygen measured in the base layer is most likely the result of air intrusion into the permeable shredded tire operations layer (which was not completely covered by waste) that covers the entire bottom of Module 6D.

\section{AEROBIC CELL}

The aerobic cell occupies approximately 2.5 acres in the southeast quadrant of Phase 1 , Module 6D.

\subsection{EXPERIMENTAL}

The experimental methods utilized are grouped into three categories: construction, monitoring, and operation. Each of these categories is discussed below. 


\subsubsection{Construction}

Construction of the aerobic cell can be generally broken down into five major tasks: waste placement, liquid addition, gas collection, air injection and surface liner installation. Each of the five tasks is discussed below. Refer to Appendix A, Table 5 for a summary of current monitoring data for the northeast anaerobic cell.

\subsubsection{Waste Placement}

Waste placement first began November 14, 2000 with an approximate 10-foot lift of waste placed on the Module 6D liner. This first lift of waste will act as a buffer between the Module 6D primary liner and the future aerobic cell. The waste was graded to promote drainage and a 60-mil HDPE geomembrane was installed to capture all leachate being generated by the aerobic cell. A sixteen-ounce geotextile was then placed on the membrane to act as a cushion for a shredded tire operations layer.

Waste placement in the aerobic cell occurred between August 6, 2001 and September 26, 2001. Waste was placed in three 10-foot lifts with 2:1 side slopes on the north, east and west (internal side slopes), and a 3:1 side slope on the south (external side slope) as presented in Detail 4. Because of the limited tipping area of the aerobic cell, self-haul waste was excluded. The use of daily cover soil during waste filling was also minimized to aid in the overall permeability of the waste. Whenever possible, greenwaste or tarps were used as alternative daily cover (ADC) and, in the event soil was placed (for example, access roads or tipping pad), the soil was removed prior to placing the next lift of waste. To further aid permeability of the waste, compaction was restricted to only 1to 2 passes with a Caterpillar 826 compactor. Instrumentation Layers 1 and 2 were placed between lifts, and base layer instrumentation was installed on the aerobic cell base liner. A summary of sensors installed on each layer is provided in Appendix A, Table 6.

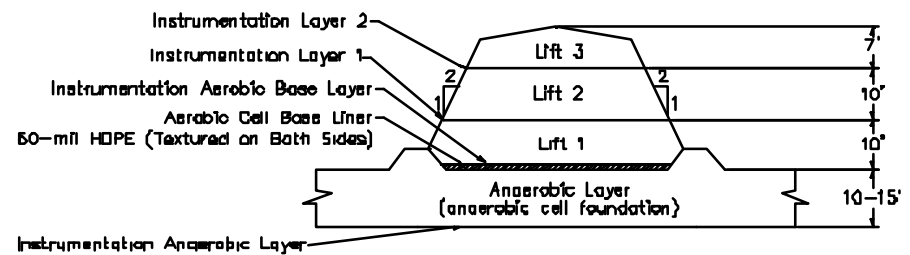

Detail 4. Aerobic Cell Cross Section

\subsubsection{Liquid Addition}

Horizontal liquid injection lines were installed in each lift of waste. Injection lines within the waste (between lifts 1 and 2, 2 and 3) were placed horizontally (north to south) at approximately 20 -foot spacing. Injection lines on top of lift 3 were placed east to west every 20 feet. Various combinations of 11/4-inch-diameter chlorinated polyvinyl chloride (CPVC) and 11/4-inch-diameter HDPE pipe were installed and perforated with ${ }^{3} /{ }_{32}$-inch-diameter holes spaced every 10 feet. Because of the elevated temperatures expected in the aerobic cell, CPVC was installed a selected locations as a redundancy in the event the HDPE piping fails (CPVC is rated for service at temperatures up to $200^{\circ} \mathrm{F}$ ). A total of 4,780 feet of injection piping was installed with a total of 326 injection holes. 
Each of the injection laterals will be connected to a 4-inch-diameter HDPE injection header. Flow rate and pressure will be monitored at each injection lateral. Leachate injection for each lateral will be monitored and controlled by individual solenoid valves connected to the SCADA system. A second redundant flow meter will monitor the total volume and flow rate being injected in the aerobic cell.

\subsubsection{Air Collection}

Horizontal air collection lines were installed between each lift of waste. Air collection lines consist of various combinations of alternating 4 and 6-inch-diameter CPVC pipe and 6 and 8inch-diameter corrugated metal pipe. Each air collection line utilizes shredded tires as the permeable media. The air collection lines between layers are spaced approximately 40 feet apart. A total of 1660 feet of horizontal air collection lines were installed. A summary of the air collection lines for the aerobic cell is shown in Appendix A, Table 7.

Each air collection line will be connected to a 12-inch-diameter air collection header that will convey the gas to and on-site blower and biofilter. Each air collection line will incorporate a premanufactured wellhead capable of controlling flow and monitoring flow rate, temperature and pressure.

\subsubsection{Surface Liner}

Vector was retained to provide design, plans and specifications for a surface lining system, including a biofilter for the treatment of the aerobic off-gas.

Since the operation of an aerobic bioreactor at the Yolo County Central Landfill was first considered, two methods of air management for oxygen delivery have been discussed. One method is to push air into the landfill and the other is to apply a vacuum and draw air through the landfill. Both methods have advantages and disadvantages. However, Yolo County has decided that the best alternative is to leave the aerobic cell covered with soil and greenwaste (shredded yard waste), but without an impermeable geomembrane, so that air could be drawn through the waste by applying a vacuum. In this way, air will enter through the cell surface and migrate to horizontal pipelines to which a vacuum is applied. Alternate operations plans could include using some of the installed pipelines as vents and others for vacuum.

Yolo County had intended to cover the aerobic cell with an exposed geomembrane with a biofilter at the top of the cell to provide some treatment of the off-gas. However, the weight of the geomembrane that would have been placed on the aerobic cell along with the weight of a sandbag surface ballast system would result in a pressure equivalent to only 0.17 inches of water. Calculations indicate that the required pressure present in the cell to force the air through the waste, to the top of the cell, and through the biofilter would result in a great deal of ballooning of the surface liner. Yolo County estimates that to operate the aerobic bioreactor with a geomembrane surface liner would require placing approximately 14.3 feet of soil on the geomembrane. This amount of soil would both be impractical to place and extremely expensive. Additionally, the expected high settlement rate would create a great deal of maintenance difficulties for the geomembrane surface liner.

Yolo County developed a design for a geomembrane surface liner for the aerobic cell and advertised for bids on the construction. The bids received were very expensive and not within 
the budget of the project. As a result of both the technical and economic difficulties encountered, it was decided that leaving the aerobic cell without a geomembrane liner is the preferred approach.

\subsubsection{Monitoring}

Temperature, moisture, leachate quantity and quality, and air pressure and composition are monitored through an array of sensors placed within the waste and in the leachate collection and recovery system (LCRS). Each sensor location on the base layer received a temperature sensor (thermistor), a linear low-density polyethylene (LLDPE) tube, and selected locations received a PVC moisture sensor. Each sensor location within the waste received a temperature sensor (thermistor), a moisture sensor (a PVC moisture sensor and in some cases a gypsum block) and a linear low-density polyethylene (LLDPE) tube. For protection, each wire and tube was encased in a 1.25-inch-diameter HDPE pipe. Refer to Appendix B, Detail 7 for a diagram of sensor locations.

Sensors on instrumentation Layers $0.5,1$, and 2 were placed on a bedding of greenwaste (shredded yard waste), or bin fines (fine pieces of greenwaste). Sensors installed on the primary liner (prior to any waste placement) were placed on the geotextile and covered with pea gravel prior to the placement of the shredded tire operations layer.

\subsubsection{Temperature}

Temperature is monitored with thermistors manufactured by Quality Thermistor, Inc. Thermistors with a temperature range of $0^{\circ} \mathrm{C}$ to $100^{\circ} \mathrm{C}$ were chosen to accommodate the temperature ranges expected in both the anaerobic and aerobic cells. To prevent corrosion, each thermistor was encased in epoxy and set in a stainless steel sleeve. All field wiring connections were made by first soldering the connection, then covering each solder joint with adhesive-lined heat shrink tubing, and then encasing the joint in electrical epoxy. Changes in temperature are measured by the change in thermistor resistivity (ohms). As temperature increases, thermistor resistance decreases.

\subsubsection{Moisture}

Moisture levels are measured with polyvinyl chloride (PVC) moisture sensors and gypsum blocks. Both the PVC moisture sensors and gypsum blocks are read utilizing the same meter. The PVC sensors are perforated 2-inch-diameter PVC pipes with two stainless steel screws spaced 8 inches apart and attached to wires to form a circuit that includes the gravel filled pipe. The PVC sensors were designed by Yolo County and used successfully during the pilot scale project. The PVC moisture sensor can provide a general, qualitative assessment of the waste's moisture content. A reading of 0 to 40 equates to no free liquid, 40 to 80 equates to some free liquid, and 80 to 100 means completely saturated conditions.

The gypsum blocks are manufactured by Electronics Unlimited and are typically used for soil moisture determinations in agricultural applications. Gypsum blocks establish equilibrium with the media in which they are placed and are, therefore, reliable at tracking increases in the soil's moisture content. However, the gypsum block can take considerable time to dry and therefore may not reflect the drying of the surrounding environment. 


\subsubsection{Leachate Quantity and Quality}

Leachate that is generated from the aerobic cell will drain to a separate leachate sump installed on top of the eastside Module D leachate collection sump. A dedicated pump is then used to remove the leachate and pump it to one of the on-site leachate storage ponds. A flow meter will measure rate and total volume pumped from the sump.

Leachate is monitored for the following field parameters: $\mathrm{pH}$, electrical conductivity, dissolved oxygen, oxidation-reduction potential, and temperature. When leachate is generated in sufficient quantities, the following parameters will be analyzed by a laboratory: dissolved solids, biochemical oxygen demand, chemical oxygen demand, organic carbon, nutrients $\left(\mathrm{NH}_{3}, \mathrm{TKN}\right.$, $\mathrm{TP})$, common ions, heavy metals and organic priority pollutants. For the first year, monitoring will be conducted monthly for the first six months and quarterly for the following six months. After the first year, monitoring will be conducted semi-annually $(\mathrm{pH}$, conductivity, and flow rate will continue to be monitored on a monthly basis as required by the State of California's amended Waste Discharge Requirements in Order 5-00-134).

\subsubsection{Pressure}

Pressure within the aerobic cell is monitored with $1 / 4$-inch inner diameter and $3 / 8$-inch outer diameter LLDPE sampling tubes. Each tube can be attached to a pressure gage and supplemental air source. By first purging the tube with the air source (to remove any liquid blockages), and then reading the pressure, an accurate gas and/or water pressure can be measured at each sensor location.

\subsubsection{Landfill Gas Composition}

Gas composition is measured utilizing a GEM-500 combustible gas meter manufactured by LANDTEC. The GEM-500 is capable of measuring methane (either as a percent by volume or percent of the lower explosive limit), carbon dioxide, and oxygen. A reading for "balance" gas is also provided (to make up 100 percent) and is assumed to be nitrogen. Currently, gas composition is analyzed from the same sampling tubes used to measure pressure.

\subsubsection{Operation}

Operation of the aerobic cell as a bioreactor will begin once the air collection system, leachate recirculation systems, and SCADA control systems are complete. At this time, we anticipate bioreactor operation to begin in early 2002 .

\subsubsection{Leachate Recirculation}

Initially, large volumes of liquid will be added to bring the waste to field capacity. Once field capacity has been reached, only enough liquid to maintain field capacity will be added. We anticipate that greater volumes of liquid (compared to the anaerobic cells) will be necessary to maintain field capacity due to the removal of liquid by the air collection system.

\subsubsection{Air Collection}

Air collection will begin as soon as the necessary piping, blower, and biofilter is installed, which is anticipated to be in early 2002 .

\subsection{Results And Discussion}

Sensor names are represented numerically by the instrumentation layer in which the sensor is located and by the assigned sensor number. The base layer is represented by a 0, Layer 1 is 
represented by a 1 , and so forth. The complete name of the sensor is denoted by the layer number - the sensor number . For example, the second sensor on Layer 1 is named 1-02.

\subsubsection{Temperature}

Temperature is monitored with thermistors manufactured by Quality Thermistor, Inc. Thermistors with a temperature range of $0^{\circ} \mathrm{C}$ to $100^{\circ} \mathrm{C}$ were chosen so they would be able to accommodate the temperature ranges expected in both the anaerobic and aerobic cells. Currently, resistance is measured manually by connecting the sensor lines to a 26 III multimeter manufactured by Fluke Corporation.

\section{Anaerobic Base Liner}

The Module 6D base liner temperatures range between $64^{\circ} \mathrm{F}$ and $86^{\circ} \mathrm{F}\left(18^{\circ} \mathrm{C}\right.$ and $\left.30^{\circ} \mathrm{C}\right)$ as presented in Appendix C, Figure 19. Locations 0-64 and 0-65 have consistently recorded higher temperatures. Although counterintuitive, this may be due to their proximity to the east side Module 6D sump, which until recently was not covered with waste.

Aerobic Layer 0

Layer 0 temperatures are increasing, and range between $102{ }^{\circ} \mathrm{F}$ and $133{ }^{\circ} \mathrm{F}\left(39{ }^{\circ} \mathrm{C}\right.$ and $\left.56{ }^{\circ} \mathrm{C}\right)$, as presented in Appendix C, Figure 20.

Layer 0.5

Temperatures from Layer 0.5 are slightly increasing, and range from $115^{\circ} \mathrm{F}$ and $136{ }^{\circ} \mathrm{F}\left(46{ }^{\circ} \mathrm{C}\right.$ to $58{ }^{\circ} \mathrm{C}$ ), as presented in Appendix C, Figure 21.

\section{Layer 1}

Layer 1 temperatures are remaining relatively steady and range between $124{ }^{\circ} \mathrm{F}$ and $160{ }^{\circ} \mathrm{F}\left(51{ }^{\circ} \mathrm{C}\right.$ to $71{ }^{\circ} \mathrm{C}$ ) as presented in Appendix C, Figure 21.

\section{Layer 2}

Layer 2 temperatures are increasing, and range between $124^{\circ} \mathrm{F}$ and $136^{\circ} \mathrm{F}\left(51^{\circ} \mathrm{C}\right.$ and $\left.58^{\circ} \mathrm{C}\right)$, as presented in Appendix C, Figure 23.

\subsubsection{Moisture}

Moisture is measured with a Model MM 4 moisture meter manufactured by Electronics Unlimited. Moisture data are unitless numbers that give a qualitative assessment rather than a quantitative measure. During the pilot scale project, Yolo County conducted laboratory tests with the PVC sensors to determine the relationship between the multimeter readings and the presence of free liquid in the PVC sensor. It was determined that a meter reading of less than 40 corresponded to an absence of free liquid. A reading between 40 and 80 corresponds to the presence of free liquid in the PVC pipe but less than saturated conditions. Readings of greater than 80 indicate saturated conditions; i.e. the PVC sensor is full of liquid.

\section{Anaerobic Base Liner}

PVC moisture levels for the base liner are presented in Appendix C, Figure 24. Moisture levels have generally remained at steady, ranging from approximately 4 to 12, indicating no free liquid.

Aerobic Layer 0 
Layer 0 PVC moisture levels remain steady with moisture levels below 0.7 as presented in Appendix C, Figure 25.

\section{Layer 0.5}

Layer 0.5 PVC moisture levels range between 35 and 67 with sensor $0.5-2$ in the no-free-liquid zone and sensors 0.5-1 and 0.5-3 in the some-free-liquid zone as presented in Appendix C,

Figure 26.

\section{Layer 1}

Layer 1 PVC moisture levels vary considerably from nearly 0 to 73 as presented in Appendix C, Figure 27.

\section{Layer 2}

Layer 2 PVC moisture levels vary considerably from nearly 0 to 73 as presented in Appendix C, Figure 28.

\subsubsection{Leachate Quantity And Quality}

To date, leachate has not been generated from the aerobic cell.

\subsubsection{Pressure}

Pressure measurements are taken from sampling tubes with a DWYER Instruments, Inc., "Magnehelic" pressure gage. Pressure measurements can be either positive or negative, although a vacuum has not yet been applied to the air extraction lines, so negative pressures are not expected at this time. Positive pressures can result from both the generation of landfill gas and saturated liquid conditions.

\section{Anaerobic Base Liner}

Pressure readings from the anaerobic base-liner pressure tubes are currently positive and below 0.25 centimeters of water ( 0.10 inches of water) as presented in Appendix C, Figure 29.

\section{Aerobic Layer 0}

Pressure readings from the aerobic Layer 0 remain positive and below 0.13 centimeters of water (0.05 inches of water) as presented in Appendix C, Figure 30.

\section{Layer 1}

Pressure readings from Layer 1 remain positive and below 0.25 centimeters of water (0.10 inches of water) as presented in Appendix C, Figure 31.

Layer 2

Pressure readings from Layer 2 remain positive and below 0.25 centimeters of water (0.10 inches of water) as presented in Appendix C, Figure 32.

\subsubsection{Landfill Gas Composition}

Gas composition is measured from sampling tubes on each layer of the cells with the GEM-500. Because liquid will damage the GEM, pressurized air is first forced through the tubes to remove any liquid, then the tube lines are purged with a vacuum pump and hooked up to the GEM to analyze the gas composition. 


\section{Anaerobic Base Liner}

Data presented in Appendix C, Table 13 indicates fluctuating methane, carbon dioxide, and oxygen levels. These fluctuating readings are most likely due to having a portion of the permeable shredded tire operations layer (in the vicinity of the east side sump) not completely covered by waste.

Aerobic Layer 0

Gas composition for the aerobic Layer 0 indicate generally depleted oxygen levels, low methane concentrations and decreasing carbon dioxide concentrations as presented in Appendix C, Table 14.

\section{Layer 1}

Data from Appendix C, Table 15 suggests waste in layer 1 is still undergoing aerobic decomposition.

\section{Layer 2}

Data from Appendix C, Table 16 suggests waste in layer 1 is still undergoing aerobic decomposition.

\section{MODULE 6D BASE LINER}

The three bioreactor cells share a common composite liner system, designated the Module 6D primary liner. This composite liner system was constructed in 1999 and was designed to exceed the requirements of Title 27 of CCR and Subtitle D of the Federal guidelines.

\subsection{EXPERIMENTAL}

The experimental methods utilized are grouped into two categories: construction and monitoring. Each of these categories is discussed below.

\subsubsection{Construction}

Construction of the Module 6D primary liner system can generally be separated into two tasks: grading and base liner assembly.

\subsubsection{Grading}

The base layer of Module D was constructed in a ridge and swale configuration, enabling the west-side 6-acre anaerobic cell to be hydraulically separated from the northeast anaerobic cell and the aerobic cell in the southeast quadrant. The base layer slopes 2 percent inward to two central collection v-notch trenches located on the southeast and southwest side of Module D (Detail 5). Each of the trenches drain at 1 percent to their respective leachate collection sumps located at the south side of the module. 


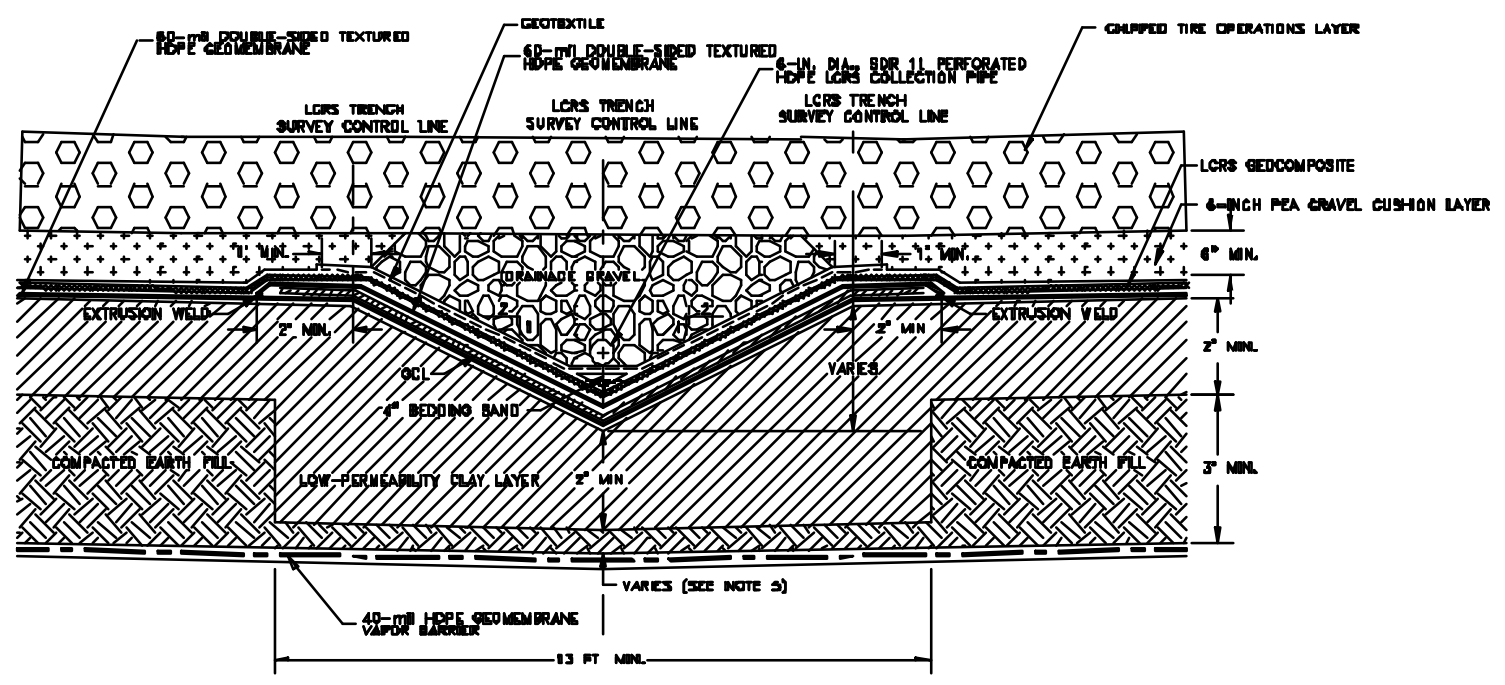

\section{Detail 5. Module D Bottom Liner and Leachate Collection Trench Cross-Section}

\subsubsection{Base Liner Assembly}

The liner is composed, from top to bottom, of the following materials: an operations/drainage layer consisting of 2 feet of chipped tires (permeability $[\mathrm{k}]>1$ centimeter per second $[\mathrm{cm} / \mathrm{s}]$ ), 6inches of pea gravel, geocomposite drain net, a 60-mil high density polyethylene (HDPE) geomembrane, a 2-foot-thick compacted clay liner $\left(\mathrm{k}<6 \times 10^{-9} \mathrm{~cm} / \mathrm{s}\right), 3$ feet of compacted earth fill $\left(\mathrm{k}<1 \times 10^{-8} \mathrm{~cm} / \mathrm{s}\right)$, a 40-mil HDPE vapor barrier layer, and a clay subgrade with 90-percent (ASTM D1557) relative compaction ${ }^{3}$ (Detail 6).

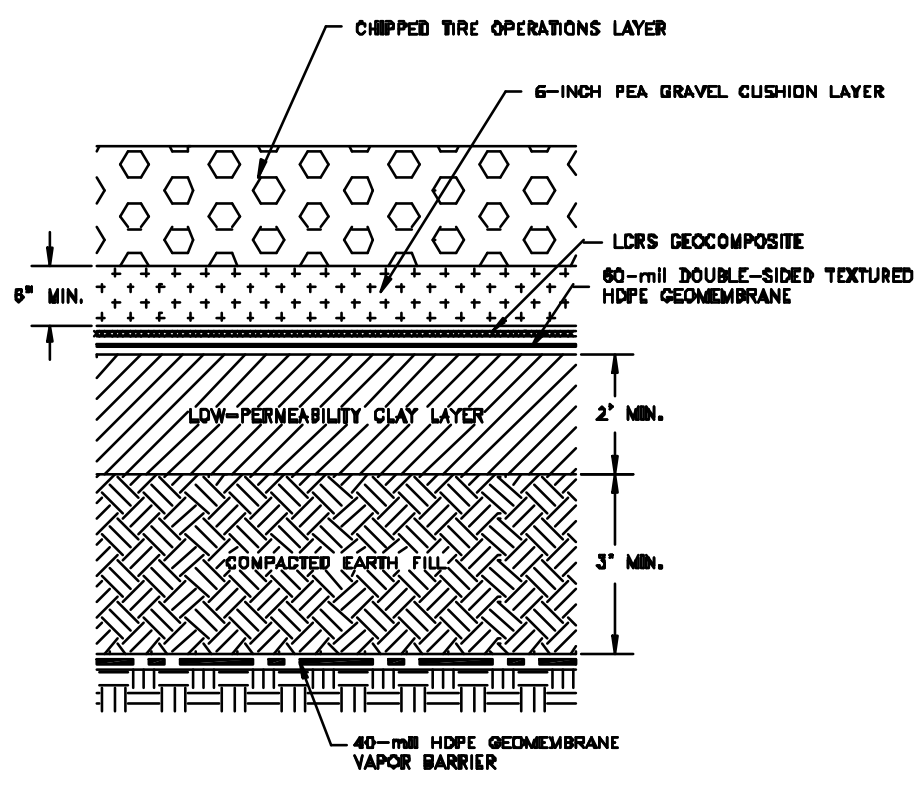

Detail 6. Module D Bottom Liner Cross-Section

\footnotetext{
${ }^{3}$ Golder Associates, "Final Report, Construction Quality Assurance, Yolo County Central Landfill, WMU 6, Module D, Phase 1 Expansion", December 1999.
} 


\subsubsection{Monitoring}

As part of the requirements specified under Waste Discharge Requirements in Order 5-00-134, Yolo County is required to monitor liquid buildup on the liner. Under typical landfilling, liquid buildup on a Class III composite liner system must be maintained to less than 1 foot. In order to gain approval from the California Regional Water Quality Control Board to operate Module 6D as a bioreactor, Yolo County must maintain less than 4-inches of liquid buildup on the Module 6D primary liner ${ }^{4}$. Head over the liner is monitored through a series of pressure transducers and sampling tubes either in or next to the two leachate collection trenches. In addition, sampling tubes located on the Module 6D liner (designations 0-1 through 0-66) are utilized to monitor head over the liner. The sampling tubes are discussed in previous sections.

\subsubsection{Leachate Collection Trenches}

Three LLDPE sampling tubes were installed in each of the leachate collection trenches. The tubes were installed inside a 2-inch-diameter PVC pipe for protection, and terminate at different points along the trenches. The sampling tubes can be hooked up to the same "Magnahelic" pressure gage, which reads directly in inches-of-water.

Pressure transducers were installed at three locations adjacent to each leachate collection trench. Additionally, tubes were installed that terminate adjacent to each of the pressure transducer locations (Appendix B. Detail 7). The pressure transducers provide an output current between 4 and 20 milliamps, which is directly proportional to pressure. The pressure transducers installed on the Module 6D liner are Model PTX 1830 manufactured by Druck, Inc. Their pressure range is 0 to 1 pounds per square inch (psi) and have an accuracy of \pm 1 percent of full scale.

\subsection{RESULTS AND DISCUSSION}

Tubes located in the leachate collection trenches are referred to as trench liquid level (TLL) tubes. Pressure transducers and their accompanying tubes that are located adjacent to the leachate collection trenches are denoted as PT or PT-TUBE respectively.

\subsubsection{Leachate Collection Trenches}

Pressure transducers generally range between 0.13 and 1.02 centimeters of water $(0.05$ and 0.4 inches of water), and adjacent tubes range between 0 and 0.31 centimeters of water ( 0 and 0.15 inches of water) as presented in Appendix C, Figure 33. The difference between the pressure transducers and the adjacent tubes are within the range of measurement error and therefore tend to confirm each other.

Trench liquid levels range between 0 and 4.57 centimeters of water ( 0 and 1.8 inches of water). Because leachate generation and pumping data suggest very little leachate was present on the base liner it may be possible that some of the elevated readings may be due to clogging (Appendix C, Figure 34). Monitoring and evaluation of the trench liquid level tubes will continue.

\footnotetext{
${ }^{4}$ California Regional Water Quality Control Board, Central Valley Region, "Waste Discharge Requirements for the Yolo County Central Landfill, No. 5-00-134”, June 16, 2000.
} 


\section{SUPERVISORY CONTROL AND DATA ACQUISITION SYSTEM}

The Supervisory Control and Data Acquisition (SCADA) system will be used to monitor the various sensors and control the operation of the bioreactor. The field electronics will be linked by radio signal to a computer located in our Woodland office.

\subsection{HARDWARE INSTALLATION}

The data collection hardware is currently being installed in a shed located at the southern limit of Module 6D. All instrumentation installed in the west-side anaerobic, northeast anaerobic, aerobic, and on the Module 6D composite liner will be connected to an Allen-Bradley central processor which will be radio linked to a computer located in our woodland office.

\subsection{SOFTWARE PROGRAMMING}

The SCADA software is currently being developed by a consultant, A-TEEM Electrical Engineering. The first phase of software development is nearly complete and will encompass data collection from the instrumentation installed on the Module 6D liner. Once this phase of the software development is complete and fully operational, the remaining instrumentation and control components will be incorporated.

\section{CONCLUSION}

The Yolo County Bioreactor Project is proceeding as scheduled. Data is currently being collected manually with initial results within expected ranges.

\section{REFERENCES}

1. Vector Engineering, "Design Report for the Surface Liners of the Module D Phase 1 Bioreactors at the Yolo County Central Landfill", October 2001.

2. Yazdani, R., Moore, R. Dahl. K. and D. Augenstein 1998 Yolo County Controlled Landfill Bioreactor Project. Yolo County Public Works and IE M, Inc. Yolo County Public Works and I E M, Inc. report to the Urban Consortium Energy Foundation (UUCETF) and the Western Regional Biomass Energy Program, USDOE.

3. Golder Associates, "Final Report, Construction Quality Assurance, Yolo County Central Landfill, WMU 6, Module D, Phase 1 Expansion”, December 1999.

4. California Regional Water Quality Control Board, Central Valley Region, "Waste Discharge Requirements for the Yolo County Central Landfill, No. 5-00-134", June 16, 2000.

5. Yolo County, IEM, SWANA, EPA, Final Project Agreement for the Yolo County Accelerated Anaerobic and Aerobic Composting (Bioreactor) Project, September 14, 2000. 
YOLO COUNTY CENTRAL LANDFILL

EPA PROJECT XL

FULL SCALE BIOREACTOR TECHNICAL PROGRESS REPORT

APPENDIX A 
Table 1. Revised Project XL Delivery Schedule

\begin{tabular}{|c|c|}
\hline Project Task & Delivery Date \\
\hline - RWQCB approved the revised Waste Discharge Requirement Permit & June 22,2000 \\
\hline - Final draft FPA circulated to stakeholders for comments & June 22,2000 \\
\hline $\begin{array}{l}\text { - Comments received for final FPA } \\
\text { - } \quad \text { Instrumentation installation began }\end{array}$ & July 3,2000 \\
\hline - Finalize FPA and distribute for signature & July 21,2000 \\
\hline - All parties sign FPA document & September, 2000 \\
\hline - Final Rule for Yolo County XL Project published in Federal Register & August 30, 2001 \\
\hline $\begin{array}{l}\text { First lift of waste completed in the southeast corner of Module 6D. } \\
\text { This lift of waste is to be used as the foundation layer for the aerobic } \\
\text { cell liner. }\end{array}$ & January 2001 \\
\hline - Waste placement begins in the northeast 3.5 acre anaerobic bioreactor & January 2001 \\
\hline - Begin monitoring temperature and moisture of waste & January 2001 \\
\hline $\begin{array}{l}\text { - Begin waste placement in west 6-acre anaerobic cell (waste } \\
\text { placement alternates between the west and northeast anaerobic } \\
\text { bioreactors and the aerobic bioreactor to facilitate placement of } \\
\text { instrumentation, piping, etc.) }\end{array}$ & March 2001 \\
\hline $\begin{array}{l}\text { - Completed construction of aerobic cell liner and begin waste } \\
\text { placement in aerobic cell }\end{array}$ & July, 2001 \\
\hline $\begin{array}{l}\text { - Complete the following for the northeast anaerobic } 3.5 \text {-acre cell: } \\
\text { waste placement, instrumentation, leachate injection system, air } \\
\text { injection system, and gas and leachate monitoring }\end{array}$ & September 2001 \\
\hline $\begin{array}{l}\text { - Complete the following for the aerobic bioreactor: waste placement, } \\
\text { instrumentation, data acquisition and control system, leachate } \\
\text { injection system, air management system, gas and leachate } \\
\text { monitoring }\end{array}$ & November 2001 \\
\hline - Begin liquid addition to the northeast 3.5-acre anaerobic cell & November 2001 \\
\hline - Begin liquid addition and air injection in aerobic bioreactor & December 2001 \\
\hline $\begin{array}{l}\text { - Complete the following for the west anaerobic 6-acre cell: waste } \\
\text { placement, instrumentation, data acquisition and control system, } \\
\text { leachate injection system, air injection system, gas and leachate } \\
\text { monitoring, and cover system }\end{array}$ & October 2002 \\
\hline - Begin liquid injection in the west side 6-acre anaerobic bioreactor & November 2002 \\
\hline - Data collection and reporting will continue & $\begin{array}{l}\text { On-going until waste } \\
\text { stabilization is complete, } \\
\text { but dependent on } \\
\text { sustained funding levels }\end{array}$ \\
\hline
\end{tabular}


Table 2. Summary of Data for the Northeast Anaerobic Cell

\begin{tabular}{|c|c|}
\hline Description & Data \\
\hline Footprint & 3.4 acres \\
\hline Average Waste Depth & 35 feet \\
\hline Construction of the Base Liner & 1999 \\
\hline Waste Filling of Cells & $1 / 13 / 2001-8 / 3 / 2001$ \\
\hline Total \# of Waste Lifts & 4 \\
\hline Total Amount of Waste & 65,104 tons \\
\hline Total Amount of Greenwaste ADC ${ }^{2}$ & 11,060 tons \\
\hline Volume of Soil ${ }^{2}$ Within the Waste Mass & 5,970 cubic yards \\
\hline As-Placed Biodegradable Waste Tonnage $e^{3,4}$ & 29,600 tons \\
\hline As-Placed Biodegradable Greenwaste ADC Tonnage ${ }^{3,4}$ & 7,700 tons \\
\hline Ratio of Waste to Greenwaste ADC & 5.9 to 1 \\
\hline Ratio of Waste to Greenwaste ADC and Soil ${ }^{3}$ & 3.4 to 1 \\
\hline Average Density of Waste & $\begin{array}{l}1,162 \text { pounds per cubic yard, lbs/cy } \\
\text { (does not include soil or ADC) }\end{array}$ \\
\hline Total \# of Horizontal Gas Collection Lines ${ }^{5}$ & $16 \quad$ Spacings of approximately \\
\hline Layer 1 & 40 feet on center \\
\hline Layer 2 & 4 \\
\hline Layer 3 & 3 \\
\hline Layer 4 & 3 \\
\hline Total \# of Liquid Addition Lines (HDPE Pipe) ${ }^{6}$ & $25 \quad$ Spacings of approximately \\
\hline Layer 1 & $8 \quad 40$ feet on center \\
\hline Layer 2 & 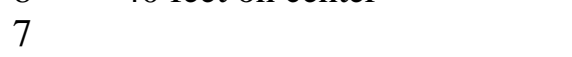 \\
\hline Layer 3 & 5 \\
\hline Layer 4 & 5 \\
\hline Total Amount of Liquid Addition Piping & 34,997 feet \\
\hline Layer 1 & 3080 feet \\
\hline Layer 2 & 2,450 feet \\
\hline Layer 3 & 1,500 feet \\
\hline Layer 4 (under construction) & to be determined \\
\hline Total \# of 3/32 inch Diameter Holes in Injection Line & 293 \\
\hline Layer 1 & 145 \\
\hline Laver 2 & 93 \\
\hline Layer 3 & 55 \\
\hline Layer 4 (under construction) & to be determined \\
\hline Surface Liner & 36-mil ${ }^{7}$ Reinforced Polypropylene \\
\hline Total \# of Moisture Sensors & Spacings of \\
\hline PVC & approximately \\
\hline Gypsum & 75 feet on center \\
\hline Total \# of Temperature Sensors & 112 \\
\hline
\end{tabular}

${ }^{T}$ Final Project Agreement, FPA

${ }^{2}$ ADC-Alternative Daily Cover

${ }^{3}$ This is an estimate

${ }^{4}$ Calculated using biodegradable fractions from Tchobanoglous et, al. (1993)

${ }^{5}$ Refer to Table 3 for a complete description of gas collection lines

${ }^{6}$ High Density Polyethylene, HDPE

${ }^{7} 1$-mil is equivalent to 0.001 inches and refers to the thickness of the liner 


\section{Table 3. Summary of Sensors for the Anaerobic Cells}

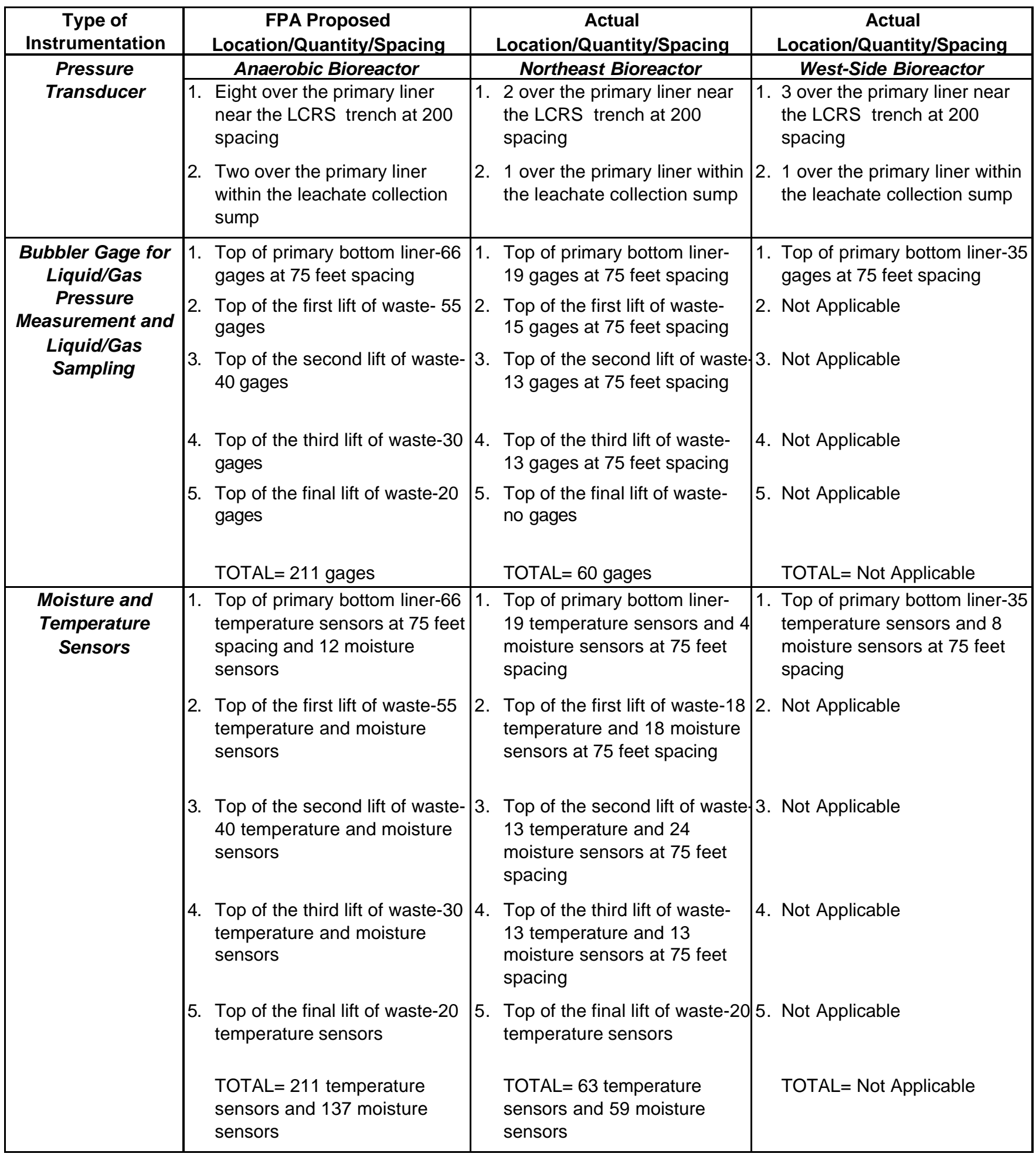


Table 4. Summary of Gas Collection Lines for the Northeast Anaerobic Cell

\begin{tabular}{|c|c|c|}
\hline $\begin{array}{c}\text { Gas } \\
\text { Collection } \\
\text { Line }^{1}\end{array}$ & Description & Spacing \\
\hline 1-G1 & Alternating 4 and 6 inch schedule $80 \mathrm{PVC}^{2}$. & 50 ' from west toe \\
\hline $1-\mathrm{G} 2$ & $\begin{array}{l}\text { Shredded tires with pipe at ends. The north end is } 40 \text { feet of schedule } 40 \\
\text { PVC with a } 10 \text { foot section of } 3 \text { inch perforated schedule } 80 \text { PVC. The } \\
\text { south end is } 40 \text { feet of } 4 \text { inch schedule } 80 \text { PVC, } 5 \text { feet of } 3 \text { inch schedule } \\
80 \text { PVC, and } 10 \text { feet of perforated HDPE. }\end{array}$ & 40' from 1-G1-NE \\
\hline 1-G3 & Alternating 4 and 6 inch schedule 80 PVC. & 40' from 1-G2-NE \\
\hline $1-\mathrm{G} 4$ & $\begin{array}{l}\text { Shredded tires with PVC pipe at ends. The south end is } 40 \text { feet of } 4 \text { inch } \\
\text { schedule } 80 \text { PVC and } 10 \text { feet of } 6 \text { inch schedule } 80 \text { PVC. The north end is } \\
40 \text { feet of } 4 \text { inch schedule } 40 \text { PVC. }\end{array}$ & 40' from $1-\mathrm{G} 3-\mathrm{NE}$ \\
\hline 1-G5 & $\begin{array}{l}\text { Shredded tires with PVC pipes at ends. The south end is } 40 \text { feet of } 4 \text { inch } \\
\text { schedule } 80 \text { PVC, } 10 \text { feet of } 6 \text { inch schedule } 80 \text { PVC, } 20 \text { feet of } 4 \text { inch } \\
\text { schedule } 80 \text { PVC, and } 5 \text { feet of } 24 \text { inch corrugated HDPE. The north end } \\
\text { is } 40 \text { feet of } 4 \text { inch schedule } 40 \text { PVC. }\end{array}$ & $40^{\prime}$ from $1-\mathrm{G} 4-\mathrm{NE}$ \\
\hline $1-\mathrm{G} 6$ & $\begin{array}{l}\text { Shredded tires with PVC pipes at ends. The south end is } 40 \text { feet of } 4 \text { inch } \\
\text { schedule } 80 \text { PVC, } 20 \text { feet of } 3 \text { inch perforated schedule } 80 \text { PVC, } 10 \text { feet of } \\
6 \text { inch schedule } 80 \text {, and } 20 \text { feet of } 3 \text { inch perforated schedule } 80 \text { PVC. } \\
\text { The north end is } 40 \text { feet of } 4 \text { inch schedule } 40 \text { PVC. }\end{array}$ & $40^{\prime}$ from $1-\mathrm{G} 5-\mathrm{NE}$ \\
\hline $2-\mathrm{G} 1$ & $\begin{array}{l}\text { Shredded tires with PVC pipes at ends. The south end is } 40 \text { feet of } 4 \text { inch } \\
\text { schedule } 80,10 \text { feet of } 6 \text { inch schedule } 80 \text {, and } 10 \text { feet of } 4 \text { inch schedule } \\
80 \text { PVC. The north end is } 40 \text { feet of } 4 \text { inch schedule } 40 \text { PVC. }\end{array}$ & 30’ from West toe \\
\hline $2-\mathrm{G} 2$ & $\begin{array}{l}\text { Alternating } 4 \text { and } 6 \text { inch schedule } 80 \text { PVC pipe for the entire length with } \\
40 \text { feet of } 4 \text { inch at the north and south end. }\end{array}$ & 40' from 2-G1-NE \\
\hline $2-\mathrm{G} 3$ & $\begin{array}{l}\text { Shredded tires with PVC pipe at the ends. The north end is } 40 \text { feet of } 4 \\
\text { inch schedule } 40 \text { PVC. The south end } 40 \text { feet of } 4 \text { inch schedule } 80 \text { PVC, } \\
20 \text { feet of } 3 \text { inch schedule } 80 \text { PVC, } 10 \text { feet of } 6 \text { inch schedule } 80 \text { PVC, and } \\
20 \text { feet } 3 \text { inch perforated schedule } 80 \text { PVC. }\end{array}$ & $40^{\prime}$ from $2-\mathrm{G} 2-\mathrm{NE}$ \\
\hline $2-\mathrm{G} 4$ & $\begin{array}{l}\text { Alternating } 6 \text { and } 3 \text { inch schedule } 80 \text { PVC pipe. The south end is } 4 \text { inch } \\
\text { schedule } 80 \mathrm{PVC} \text { and the north end is } 4 \text { inch schedule } 40 \mathrm{PVC} \text {. }\end{array}$ & $40^{\prime}$ from 2-G3-NE \\
\hline 2-G5 & $\begin{array}{l}\text { Shredded tires with pipe at the ends. The north end is } 40 \text { feet of } 4 \text { inch } \\
\text { schedule } 40 \text { PVC. The south end is } 40 \text { feet of } 4 \text { inch schedule } 80 \text { PVC, } 20 \\
\text { feet of } 3 \text { inch schedule } 80 \text { PVC, } 20 \text { feet of } 4 \text { inch schedule } 80 \text { PVC, and } 10 \\
\text { feet of } 12 \text { inch corrugated HDPE. }\end{array}$ & $40^{\prime}$ from $2-\mathrm{G} 4-\mathrm{NE}$ \\
\hline $3-\mathrm{G} 1$ & $\begin{array}{l}\text { Shredded tires with PVC pipe at the ends. The north end is } 40 \text { feet of } 4 \\
\text { inch schedule } 40 \text { PVC. The south end is } 40 \text { feet } 4 \text { inch schedule } 80 \text { and } 20 \\
\text { feet of } 8 \text { inch schedule } 40 \text {. }\end{array}$ & $45^{\prime}$ from west toe \\
\hline $3-\mathrm{G} 2$ & $\begin{array}{l}\text { Shredded tires with PVC pipe at the ends. The north end is } 40 \text { feet of } 4 \\
\text { inch schedule } 40 \text { VC. The south end is } 40 \text { feet of } 4 \text { inch schedule } 80 \text { PVC, } \\
20 \text { feet of } 8 \text { inch HDPE, and } 40 \text { feet of } 6 \text { inch HDPE. }\end{array}$ & $45^{\prime}$ from $3-\mathrm{G} 1-\mathrm{NE}$ \\
\hline $3-\mathrm{G} 3$ & $\begin{array}{l}\text { Shredded tires with PVC pipe at the ends. The north end is } 40 \text { feet of } 4 \\
\text { inch schedule } 40 \text { PVC. The south end is } 40 \text { feet of } 4 \text { inch schedule } 80 \\
\text { PVC, } 20 \text { feet of } 6 \text { inch schedule } 40 \text { PVC, and } 10 \text { feet of } 12 \text { inch corrugated } \\
\text { HDPE. }\end{array}$ & $35^{\prime}$ from 3-G2-NE \\
\hline
\end{tabular}


Table 5. Summary of Data for the Aerobic Cell

\begin{tabular}{|c|c|}
\hline Description & Data \\
\hline Footprint & 2.3 acres \\
\hline Average Waste Depth & 30 feet \\
\hline Construction of the Base Liner & August 2001 \\
\hline Waste Filling of Cells & $8 / 8 / 2001-9 / 26 / 2001$ \\
\hline Total \# of Waste Lifts & 3 \\
\hline Total Amount of Waste & 11,942 tons \\
\hline Total Amount of Greenwaste ADC ${ }^{2}$ & 2,169 tons \\
\hline Volume of Soil ${ }^{2}$ Within the Waste Mass & 347 cubic yards \\
\hline $\begin{array}{l}\text { As-Placed Biodegradable Waste Tonnage } \\
\text { As-Placed Biodegradable Greenwaste ADC Tonnage }\end{array}$ & $\begin{array}{l}\text { tons } \\
\text { tons }\end{array}$ \\
\hline Ratio of Waste to Greenwaste ADC & 5.5 to 1 \\
\hline Ratio of Waste to Greenwaste ADC and Soil ${ }^{3}$ & 4.5 to 1 \\
\hline Average Density of Waste & $\begin{array}{l}\text { pounds per cubic yard, lbs/cy (does not } \\
\text { include soil or ADC) }\end{array}$ \\
\hline $\begin{array}{l}\text { Total \# of Corrugated Metal Pipe Horizontal Air Collection Lines } \\
\text { Layer } 1\end{array}$ & $\begin{array}{ll}6 & \text { Spacings vary. } \\
3 & \end{array}$ \\
\hline $9.1 \quad$ LAYER 2 & 3 \\
\hline $\begin{array}{l}\text { Total \# of CPVC }{ }^{6} \text { Pipe Horizontal Air Collection Lines } \\
\text { Layer } 1 \\
\text { Layer } 2\end{array}$ & $\begin{array}{ll}5 & \text { Spacings vary. } \\
3 & \\
2 & \\
\end{array}$ \\
\hline $\begin{array}{l}\text { Total Amount of Air Collection Lines } \\
\text { Layer } 1 \\
\text { Layer } 2\end{array}$ & $\begin{array}{l}1660 \\
1100 \\
560\end{array}$ \\
\hline $\begin{array}{l}\text { Total \# of } \mathrm{HDPE}^{7} \text { Pipe Liquid Addition Lines } \\
\text { Layer } 1 \\
\text { Layer } 2 \\
\text { Layer } 3 \\
\end{array}$ & $\begin{array}{ll}21 & \text { Spacings approximately } \\
10 & 40 \text { feet on center to } \\
8 & \text { alternate with CPVC pipe } \\
3 & \text { for liquid addition lines. } \\
\end{array}$ \\
\hline $\begin{array}{l}\text { Total \# of CPVC Pipe Liquid Addition Lines } \\
\text { Layer } 1 \\
\text { Layer } 2\end{array}$ & $\begin{array}{ll}11 & \text { Spacings of approximately } \\
6 & 40 \text { feet on center to alternate } \\
5 & \text { with HDPE pipe } \\
& \text { for liquid addition lines. } \\
\end{array}$ \\
\hline $\begin{array}{l}\text { Total Amount of Liquid Addition Piping } \\
\text { Layer } 1 \\
\text { Layer } 2 \\
\text { Layer } 3 \\
\end{array}$ & $\begin{array}{l}4,780 \text { feet } \\
2,870 \text { feet } \\
1,400 \text { feet } \\
510 \text { feet } \\
\end{array}$ \\
\hline $\begin{array}{l}\text { Total \# of } 3 / 32 \text { inch Diameter Holes in Injection Lines } \\
\text { Layer } 1 \\
\text { Layer } 2 \\
\text { Layer } 3\end{array}$ & $\begin{array}{l}326 \\
186 \\
97 \\
43\end{array}$ \\
\hline $\begin{array}{l}\text { Total \# of Moisture Sensors } \\
\text { PVC } \\
\text { Gypsum }\end{array}$ & Spacings vary \\
\hline Total \# of Temperature Sensors & 62 \\
\hline $\begin{array}{l}{ }^{1} \text { Final Project Agreement, FPA } \\
{ }^{2} \text { ADC-Alternative Daily Cover } \\
{ }^{3} \text { This is an estimate } \\
{ }^{4} \text { Calculated using biodegradable fractions from Tchobanoglo } \\
{ }^{5} \text { Refer to table A for a complete description of air collection } \\
{ }^{6} \text { Chlorinated Polyvinyl Chloride, CPVC } \\
{ }^{7} \text { High Density Polyethylene, HDPE }\end{array}$ & 93) \\
\hline
\end{tabular}


Table 6. Summary of Sensors for the Aerobic Cell

\begin{tabular}{|c|c|c|}
\hline $\begin{array}{c}\text { Type of } \\
\text { Instrumentation }\end{array}$ & FPA Proposed Location/Quantity/Spacing & Actual Location/Quantity/Spacing \\
\hline Pressure Transducer & $\begin{array}{l}\text { 1. Two over the primary liner at } 200 \text { feet spacing } \\
\text { 2. One within the leachate sump }\end{array}$ & \begin{tabular}{|l} 
1. 1 over the primary liner \\
2. 1 within the leachate sump
\end{tabular} \\
\hline $\begin{array}{l}\text { Bubbler Gage for } \\
\text { Liquid/Gas Pressure } \\
\text { Measurement and } \\
\text { Liquid/Gas Sampling }\end{array}$ & $\begin{array}{l}\text { 1. Top of the aerobic bottom liner- } 48 \text { gages at } 50 \\
\text { feet spacing } \\
\text { 2. Top of the first lift of waste- } 24 \text { gages } \\
\text { 3. Top of the second lift of waste- } 20 \text { gages } \\
\text { 4. Top of the final lift of waste- } 20 \text { gages } \\
\text { TOTAL }=112 \text { gages }\end{array}$ & $\begin{array}{l}\text { 1. Top of the aerobic bottom liner- } 12 \text { gages at } \\
75 \text { feet spacing } \\
\text { 2. Top of the first lift of waste- } 26 \text { gages } \\
\text { 3. Top of the second lift of waste- } 16 \text { gages } \\
\text { 4. Top of the final lift of waste- no gages } \\
\text { TOTAL }=54 \text { gages }\end{array}$ \\
\hline $\begin{array}{c}\text { Moisture and } \\
\text { Temperature Sensors }\end{array}$ & $\begin{array}{l}\text { 1. Top of the aerobic bottom liner-48 temperature } \\
\text { and } 12 \text { moisture sensors } \\
\text { 2. Top of the first lift of waste- } 24 \text { temperature and } \\
\text { moisture sensors } \\
\text { 3. Top of the second lift of waste- } 20 \text { temperature } \\
\text { and moisture sensors } \\
\text { 4. Top of the final lift of waste- } 20 \text { temperature and } \\
\text { moisture sensors } \\
\text { TOTAL= } 112 \text { temperature sensors and } 76 \\
\text { moisture sensors }\end{array}$ & $\begin{array}{l}\text { 1. Top of the aerobic bottom liner- } 12 \\
\text { temperature and } 2 \text { moisture sensors at } 75 \\
\text { feet spacing } \\
\text { 2. Top of the first lift of waste- } 26 \text { temperature } \\
\text { and } 26 \text { moisture sensorsat various spacings } \\
\text { 3. Top of the second lift of waste- } 18 \\
\text { temperature and } 21 \text { moisture sensors at } \\
\text { various spacings } \\
\text { 4. Top of the final lift of waste-no temperature or } \\
\text { moisture sensors } \\
\text { TOTAL= } 56 \text { temperature sensors and } 49 \\
\text { moisture sensors }\end{array}$ \\
\hline
\end{tabular}


Table 7. Summary of Air Collection Lines for the Aerobic Cell

\begin{tabular}{|c|c|c|}
\hline $\begin{array}{l}\text { Air Collection } \\
\text { Line }^{1} \\
\end{array}$ & Description & Spacing \\
\hline $1-\mathrm{A} 1$ & $\begin{array}{l}\text { Alternating } 10 \text { foot lengths of } 4 \text { and } 6 \text { inch schedule } 80 \\
\text { CPVC }^{2} \text {. }\end{array}$ & $\begin{array}{l}30 \text { ' from west } \\
\text { toe }\end{array}$ \\
\hline $1-\mathrm{A} 2$ & $\begin{array}{l}\text { Alternating } 10 \text { foot lengths of } 6 \text { and } 8 \text { inch corrugated metal } \\
\text { pipe. }\end{array}$ & $\begin{array}{l}\text { 40' from 1-A1- } \\
\text { SE }\end{array}$ \\
\hline $1-\mathrm{A} 3$ & $\begin{array}{l}\text { Alternating } 10 \text { foot lengths of } 6 \text { and } 8 \text { inch corrugated metal } \\
\text { pipe. }\end{array}$ & $\begin{array}{l}40 \text { ' from 1-A2- } \\
\text { SE }\end{array}$ \\
\hline $1-\mathrm{A} 4$ & $\begin{array}{l}\text { Alternating } 10 \text { foot lengths of } 4 \text { and } 6 \text { inch schedule } 80 \\
\text { CPVC. }\end{array}$ & $\begin{array}{l}\text { 40' from 1-A3- } \\
\text { SE }\end{array}$ \\
\hline 1-A5 & $\begin{array}{l}\text { Alternating } 10 \text { foot lengths of } 6 \text { and } 8 \text { inch corrugated metal } \\
\text { pipe. }\end{array}$ & $\begin{array}{l}40 \text { ' from 1-A4- } \\
\text { SE }\end{array}$ \\
\hline 1-A6 & $\begin{array}{l}\text { Alternating } 10 \text { foot lengths of } 4 \text { and } 6 \text { inch schedule } 80 \\
\text { CPVC. }\end{array}$ & $\begin{array}{l}\text { 40' from 1-A5- } \\
\text { SE }\end{array}$ \\
\hline 2-A1 & $\begin{array}{l}\text { Alternating } 10 \text { foot lengths of } 6 \text { and } 8 \text { inch corrugated metal } \\
\text { pipe. }\end{array}$ & $\begin{array}{l}25 \text { ' from west } \\
\text { toe }\end{array}$ \\
\hline $2-\mathrm{A} 2$ & $\begin{array}{l}\text { Alternating } 10 \text { foot lengths of } 4 \text { and } 6 \text { inch schedule } 80 \\
\text { CPVC. }\end{array}$ & $\begin{array}{l}\text { 40' from 2-A1- } \\
\text { SE }\end{array}$ \\
\hline $2-\mathrm{A} 3$ & $\begin{array}{l}\text { Alternating } 10 \text { foot lengths of } 6 \text { and } 8 \text { inch corrugated metal } \\
\text { pipe. }\end{array}$ & $\begin{array}{l}\text { 40' from 2-A2- } \\
\text { SE }\end{array}$ \\
\hline $2-\mathrm{A} 4$ & $\begin{array}{l}\text { Alternating } 10 \text { foot lengths of } 4 \text { and } 6 \text { inch schedule } 80 \\
\text { CPVC. }\end{array}$ & $\begin{array}{l}40 \text { ' from 2-A3- } \\
\text { SE }\end{array}$ \\
\hline $2-\mathrm{A} 5$ & $\begin{array}{l}\text { Alternating } 10 \text { foot lengths of } 6 \text { and } 8 \text { inch corrugated metal } \\
\text { pipe. }\end{array}$ & $\begin{array}{l}\text { 40' from 2-A4- } \\
\text { SE }\end{array}$ \\
\hline
\end{tabular}

${ }^{1}$ Air Collection Line Nomenclature: Layer \# - A (for air) and air collection line \# ${ }^{2}$ Chlorinated Polyvinyl Chloride, PVC 
YOLO COUNTY CENTRAL LANDFILL

EPA PROJECT XL

FULL SCALE BIOREACTOR TECHNICAL PROGRESS REPORT

APPENDIX B

$-34-$ 


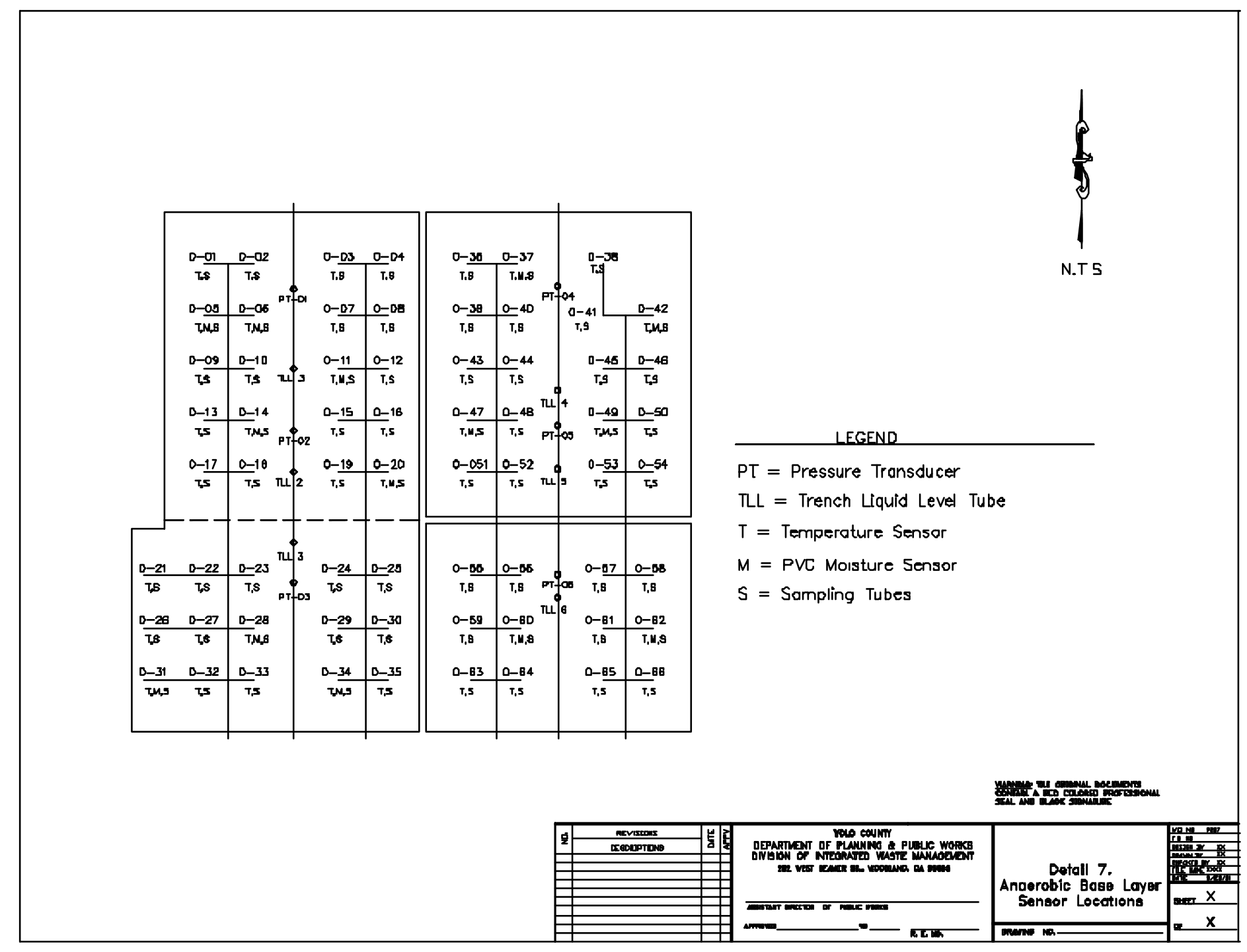




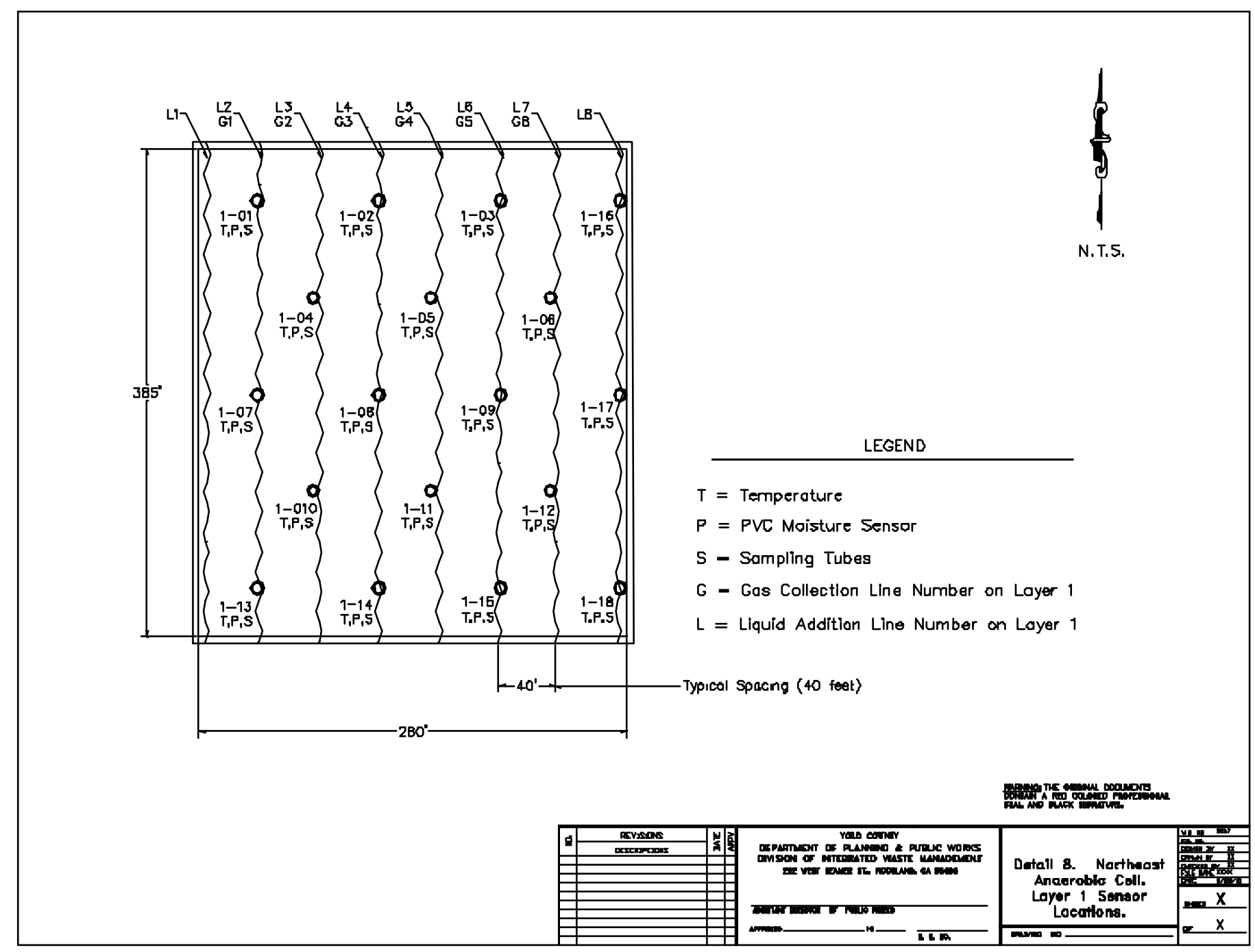




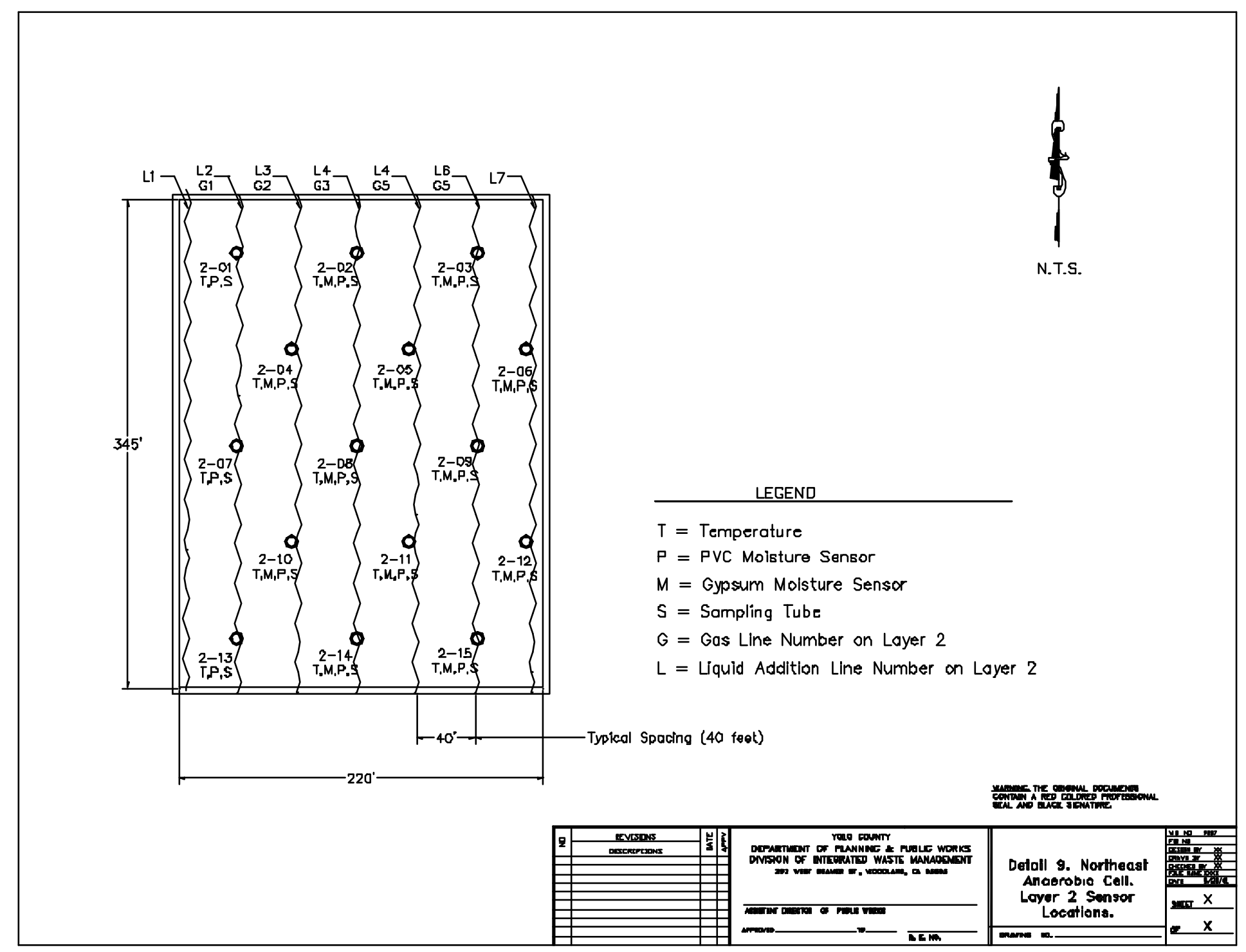




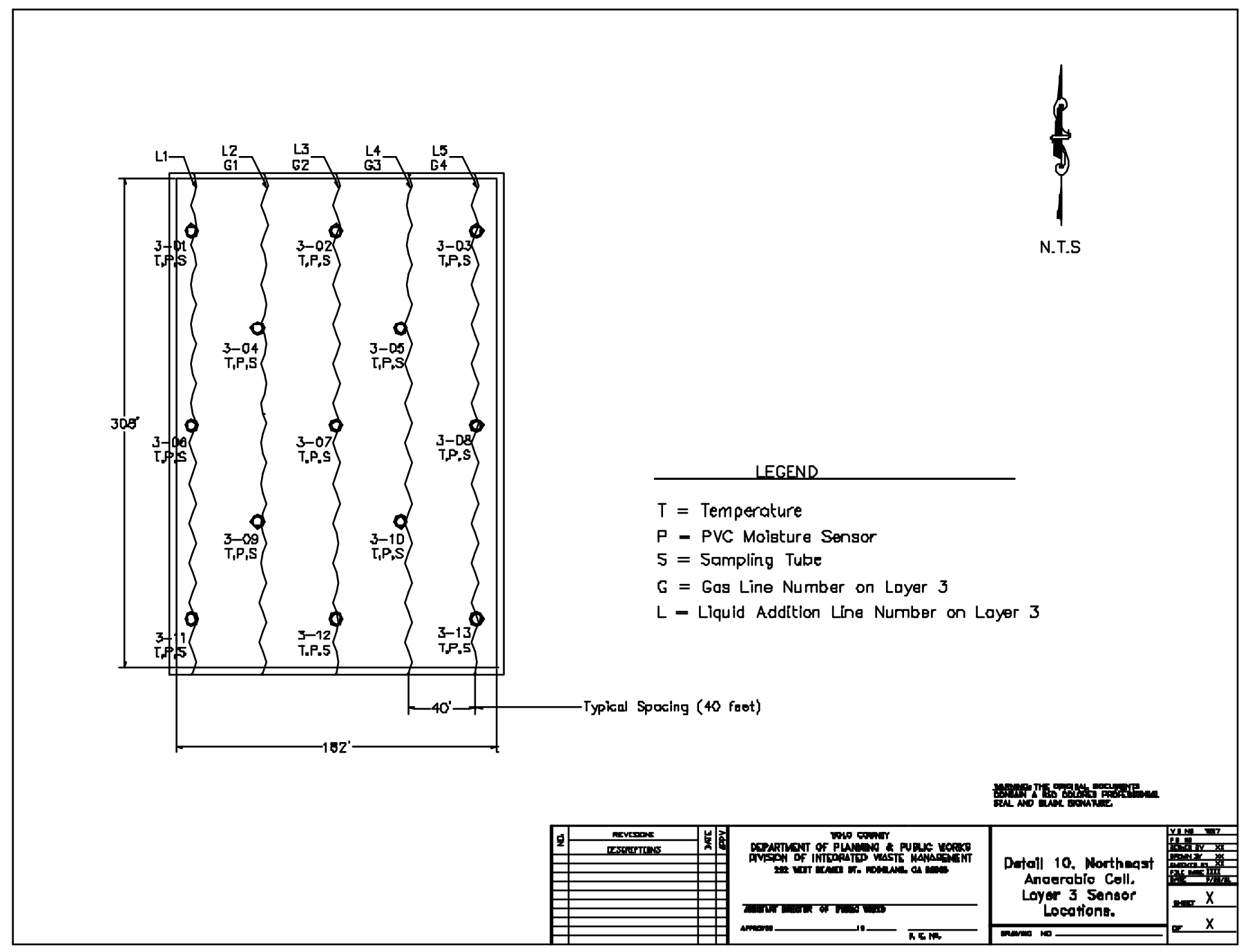


YOLO COUNTY CENTRAL LANDFILL

EPA PROJECT XL

FULL SCALE BIOREACTOR TECHNICAL PROGRESS REPORT

APPENDIX C

- 39- 
Figure 1. Northeast Anaerobic Cell Base Layer Temperature Readings

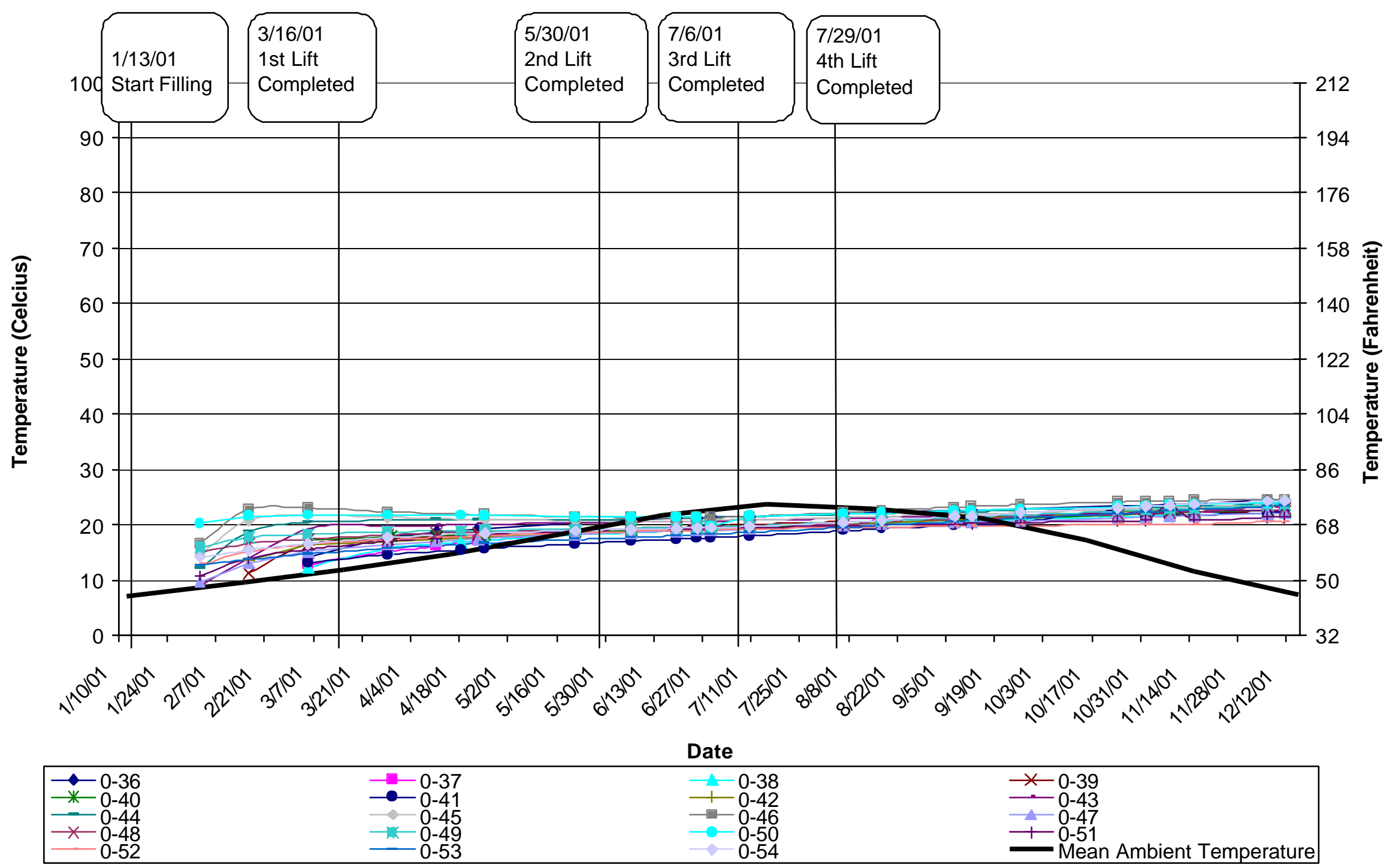


Figure 2. Northeast Anaerobic Cell Layer 1 Temperature Readings

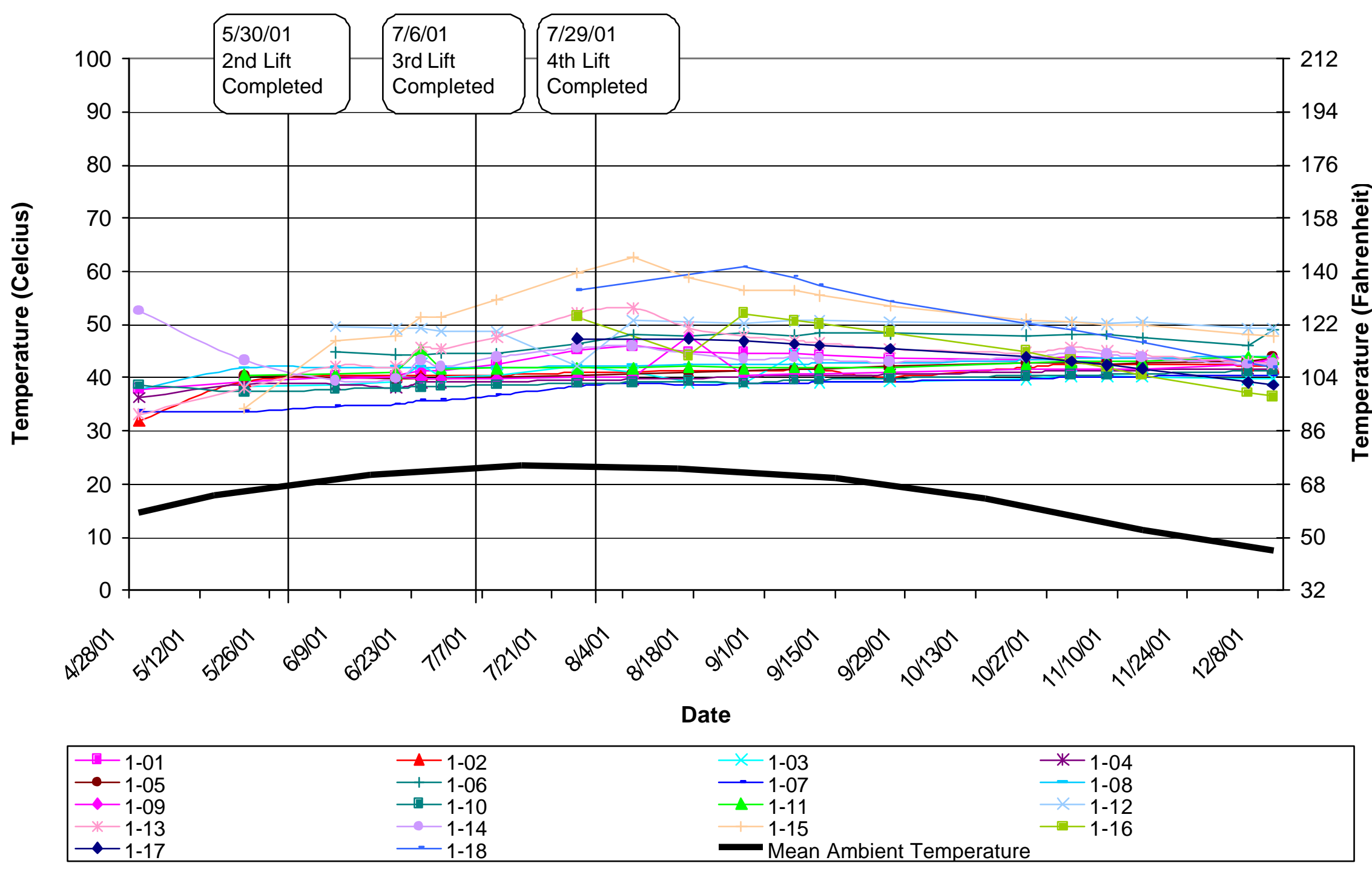


Figure 3. Northeast Anaerobic Cell Layer 2 Temperature Readings

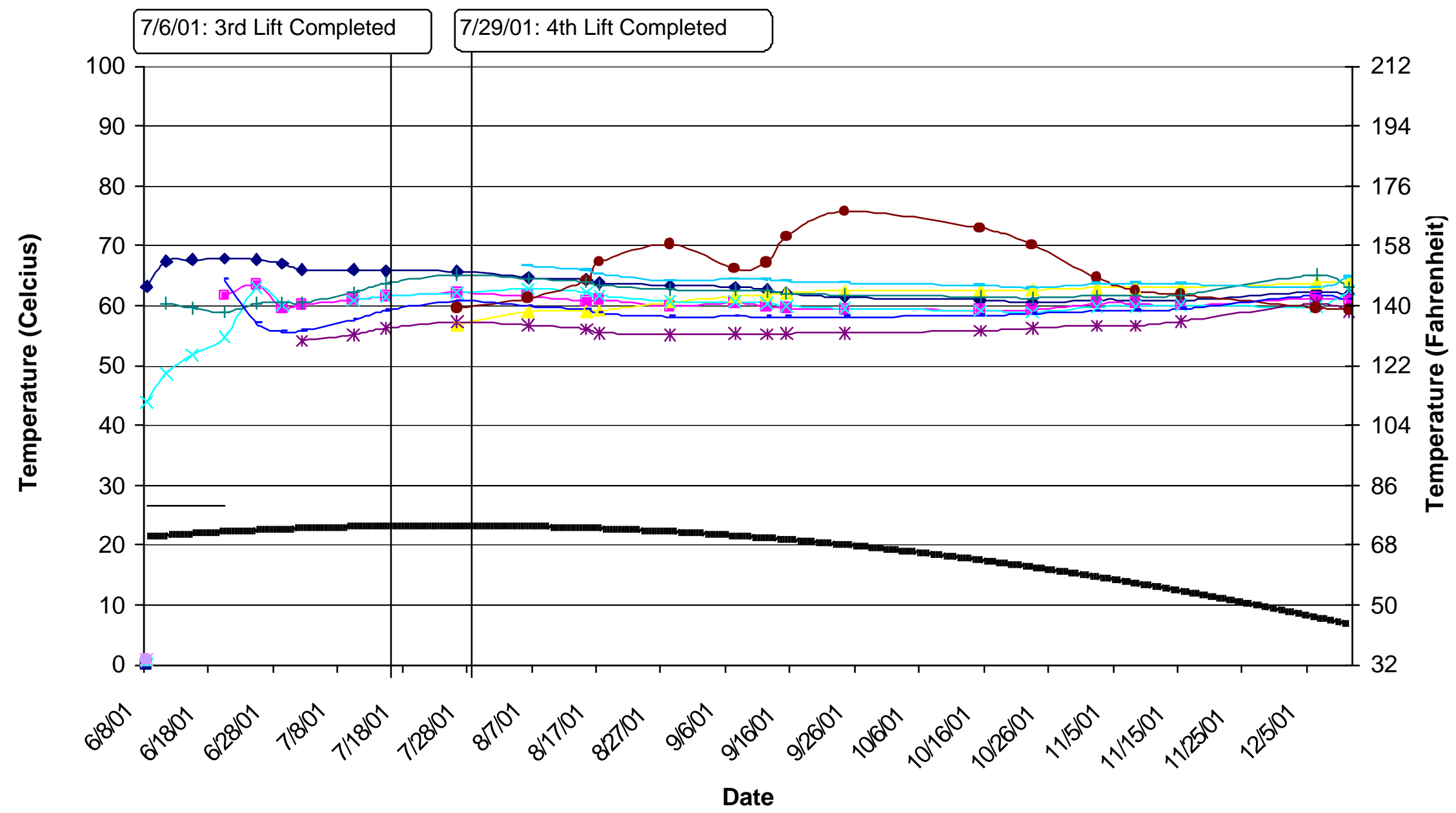

\begin{tabular}{|llll}
\hline$-2-01$ & $-2-02$ & $-2-03$ & $-2-04$ \\
$-2-05$ & $-2-06$ & $-2-07$ & $-2-08$ \\
$-2-09$ & $-2-10$ & $-2-11$ & $-2-12$
\end{tabular}


Figure 4. Northeast Anaerobic Cell Layer 3 Temperature Readings

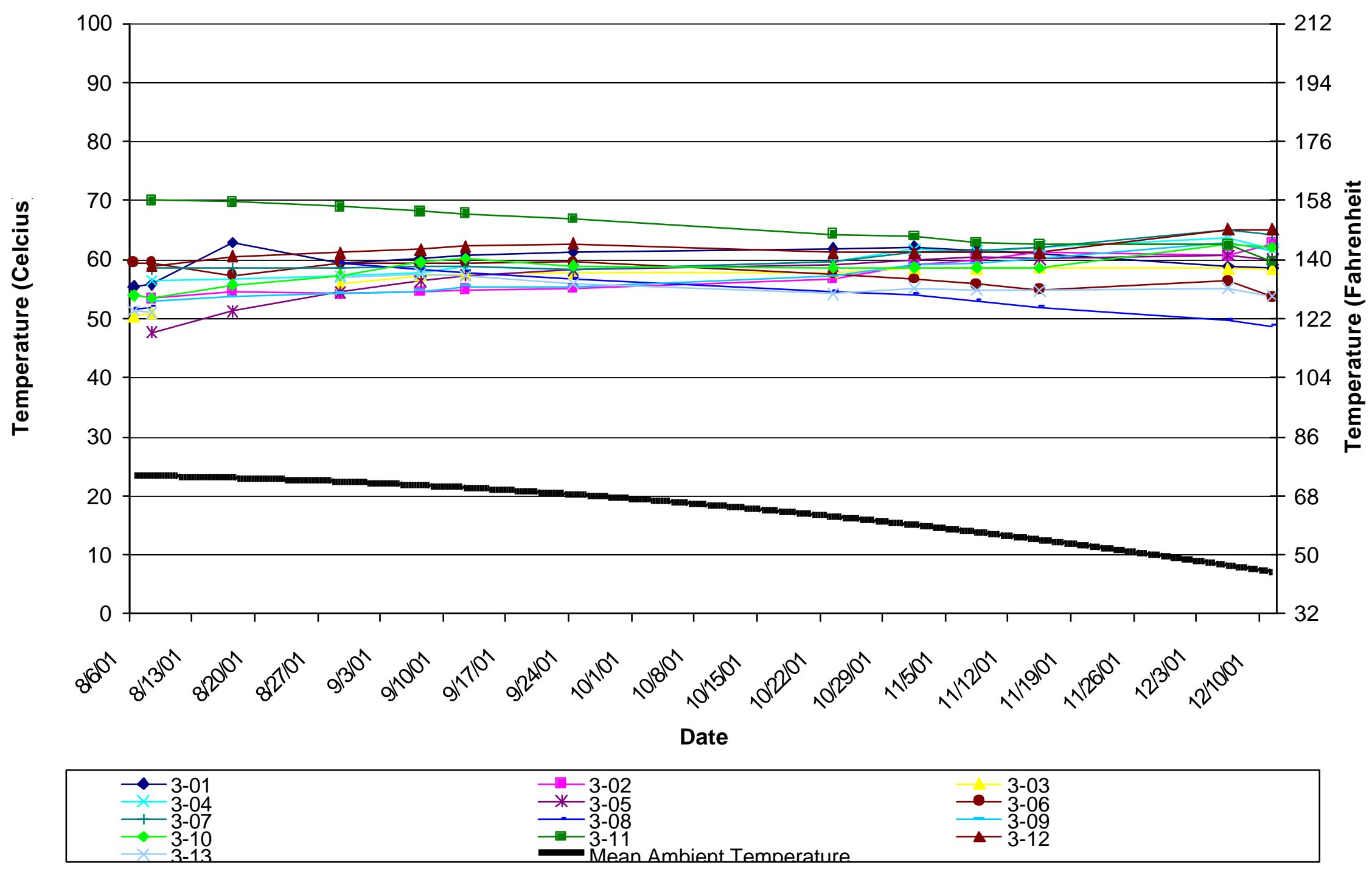


Figure 5. Northeast Anaerobic Cell Base Layer Moisture Readings (PVC Moisture Sensors)

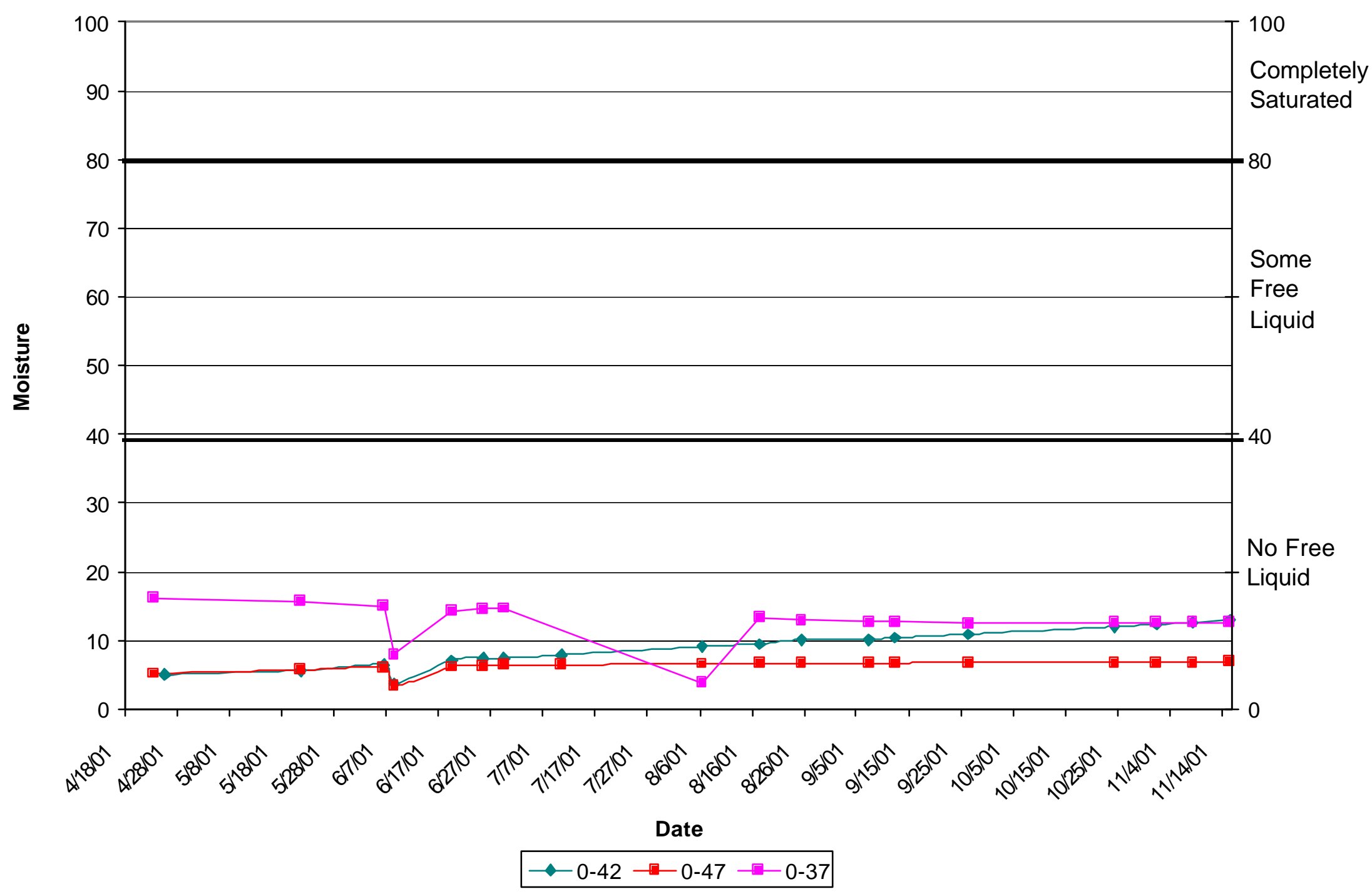


Figure 6. Northeast Anaerobic Cell Layer 1 Moisture Readings (PVC Moisture Sensors)

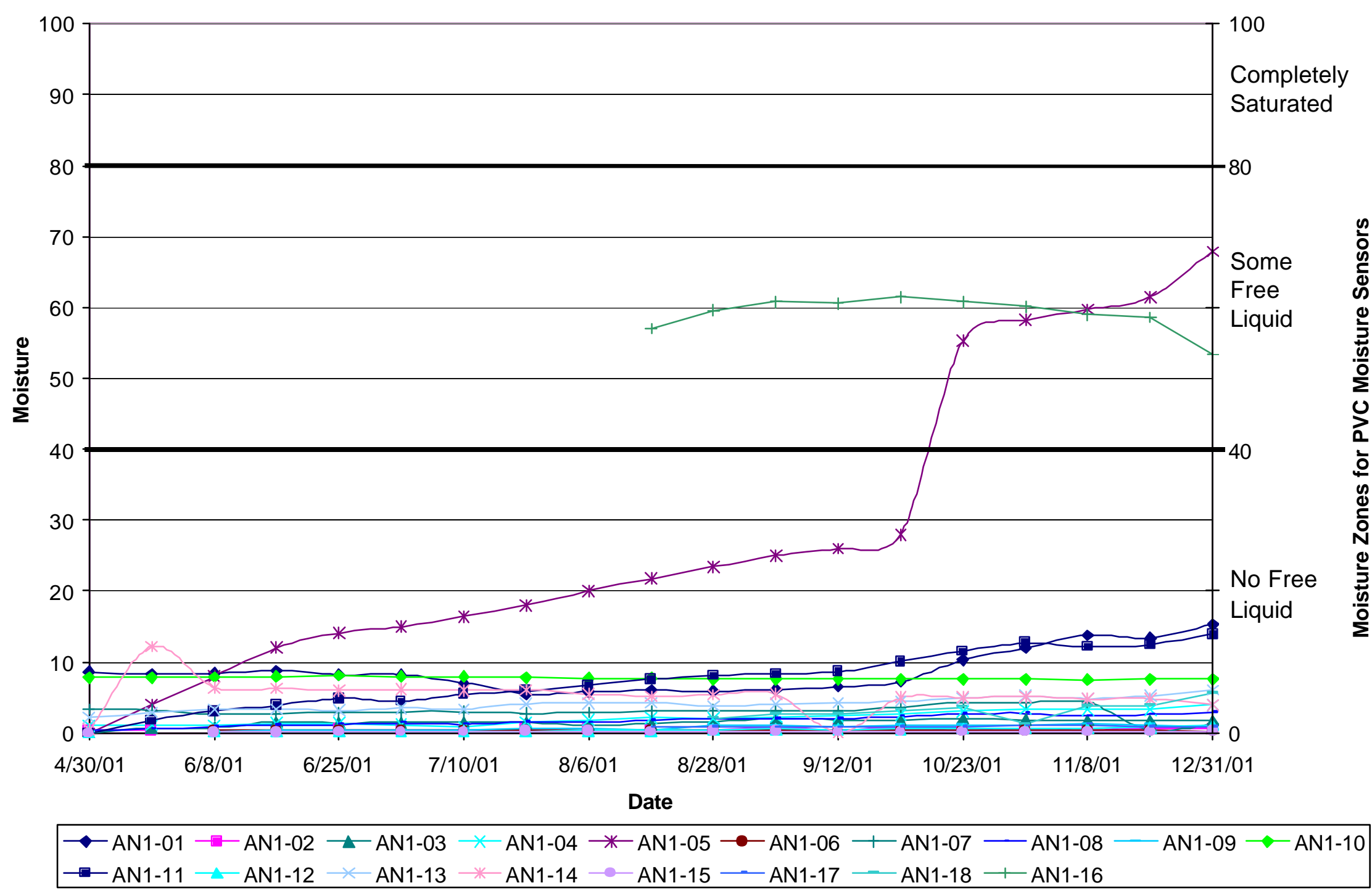


Figure 7. Northeast Anaerobic Cell Layer 2 Moisture Readings (PVC Moisture Sensors)

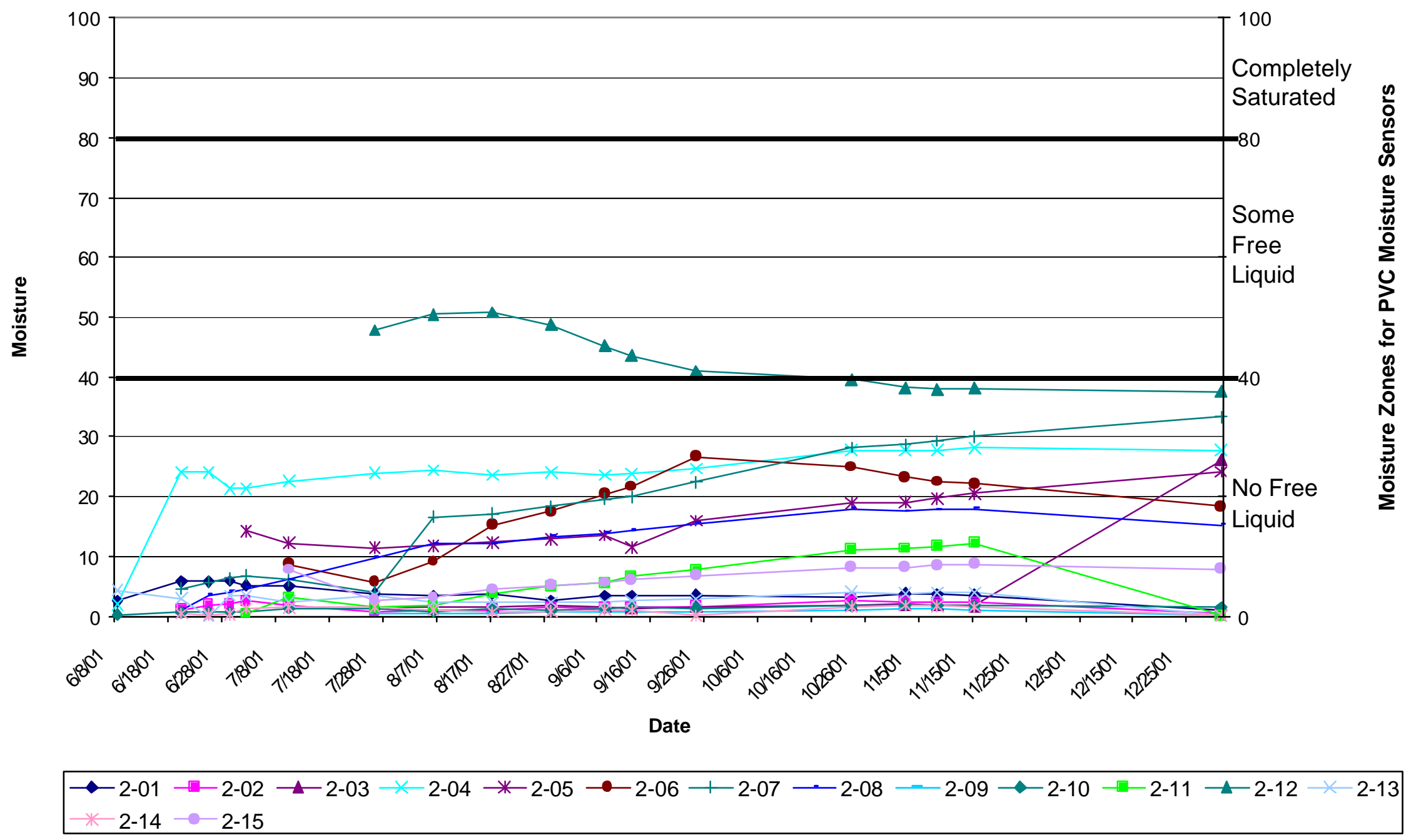


Figure 8. Northeast Anaerobic Cell Layer 2 Moisture Readings (Gypsum Moisture Sensors)

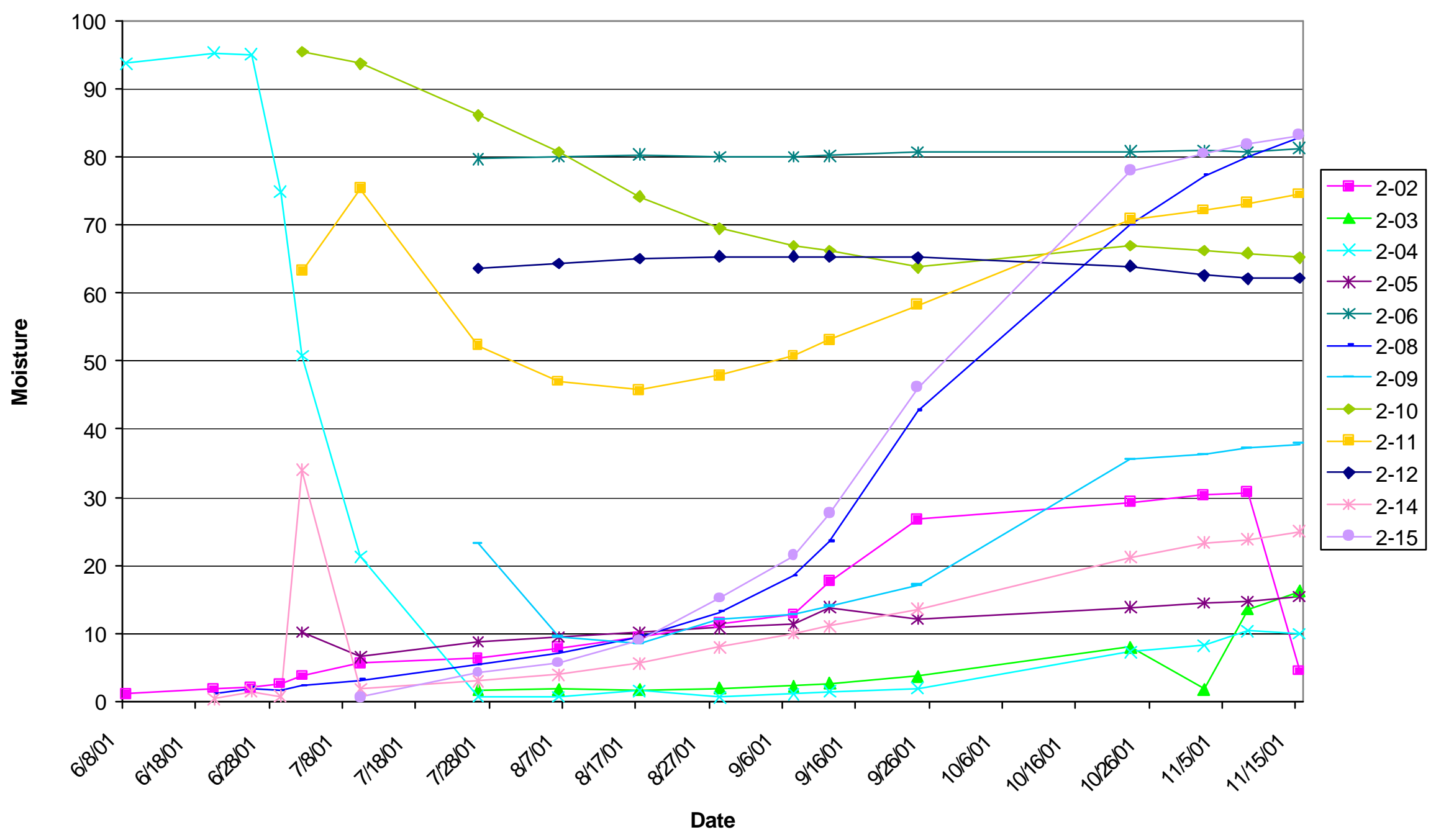


Figure 9. Northeast Anaerobic Cell Layer 3 Moisture Readings (PVC Moisture Sensors)

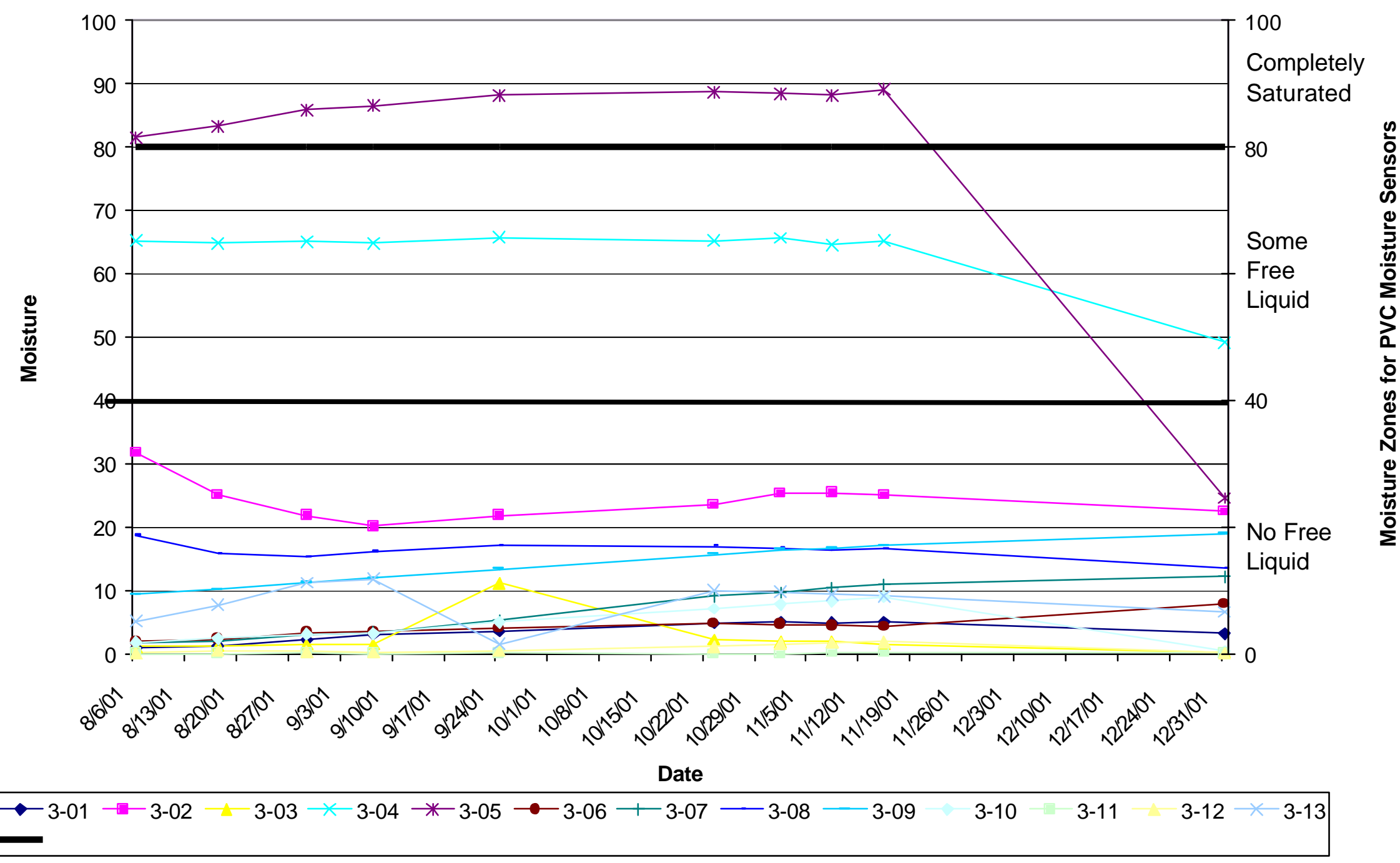


Figure 10. Northeast Anaerobic Cell Base Layer Tube Readings

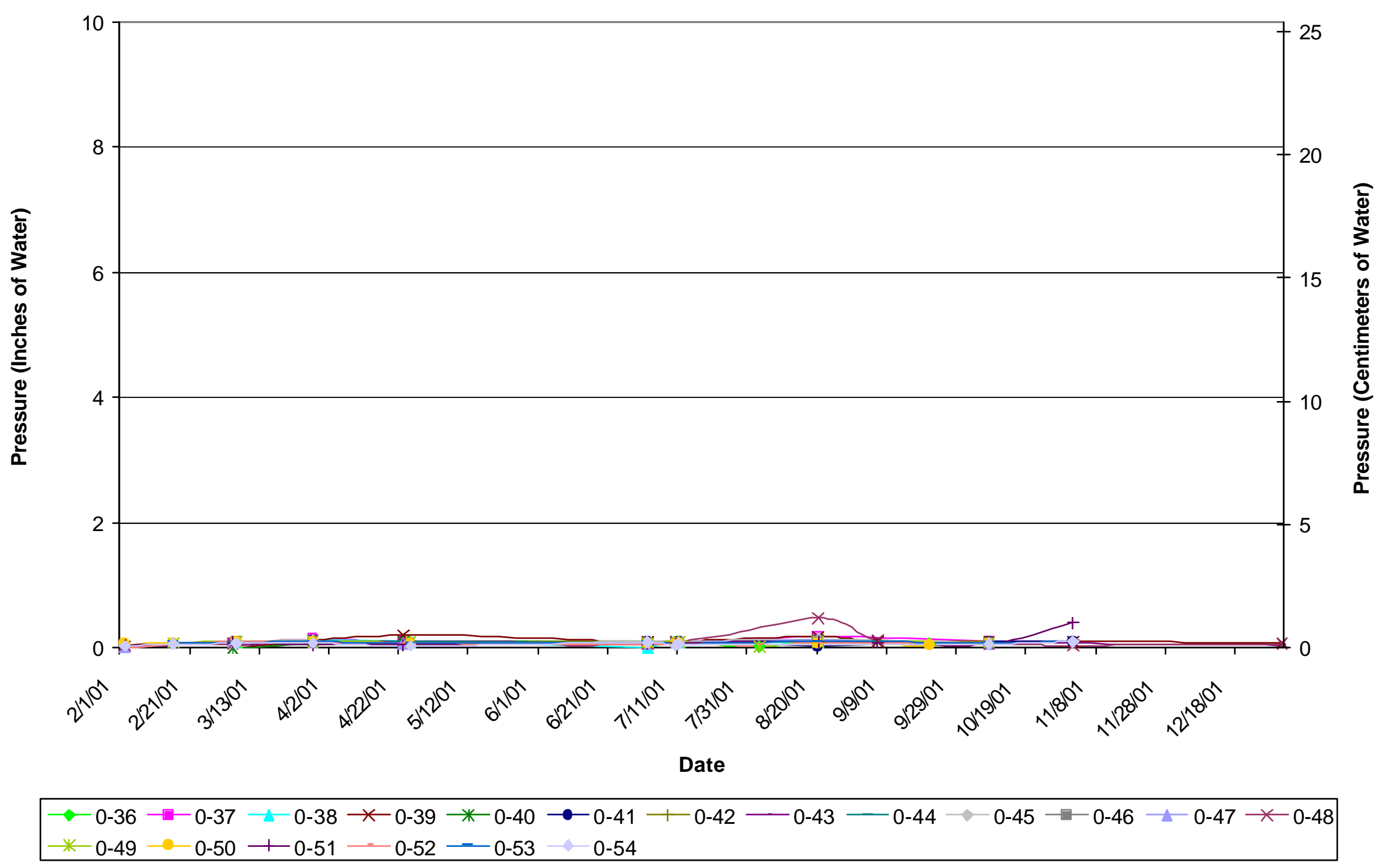




\section{Figure 11. Northeast Anaerobic Cell Layer 1 Tube Readings}

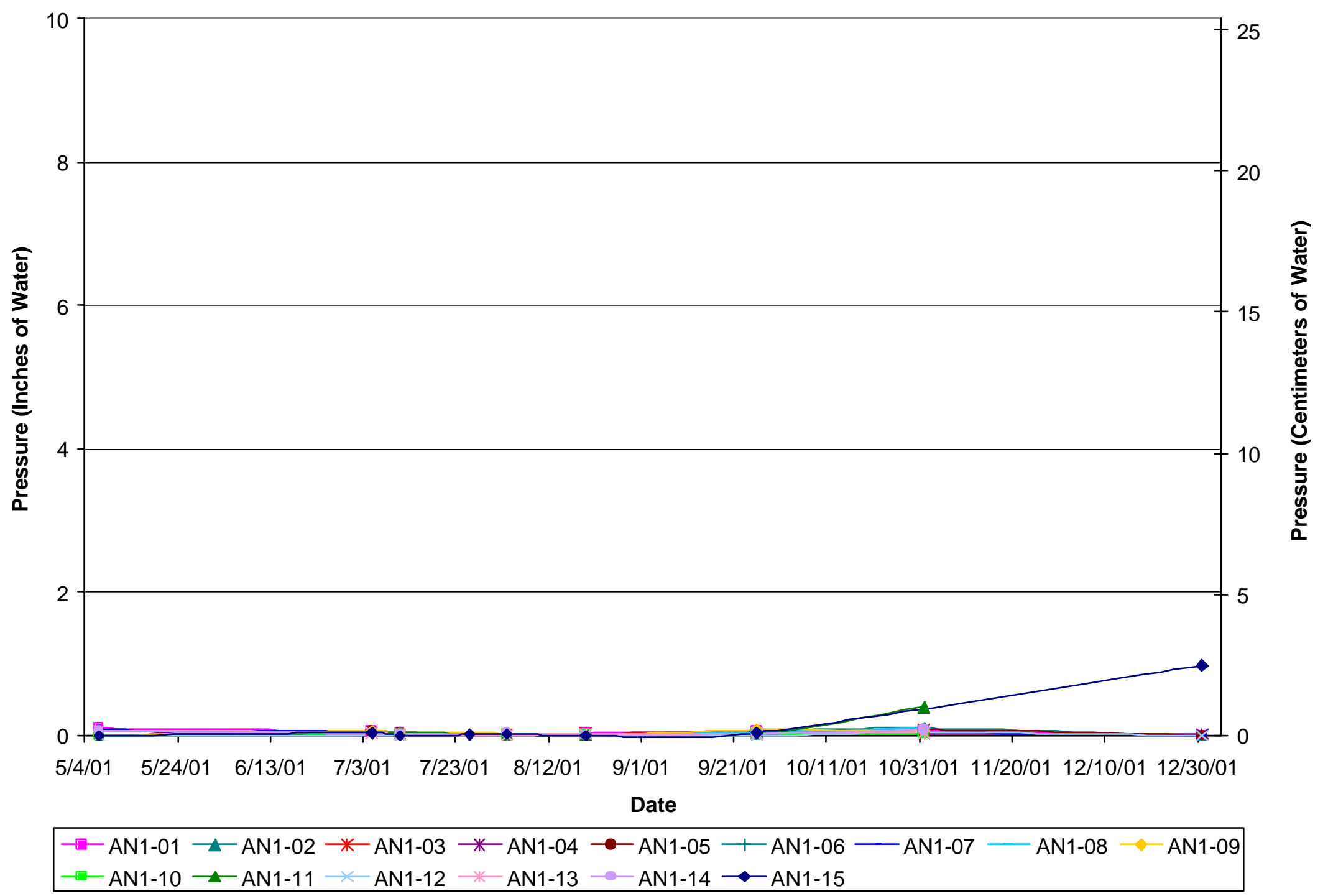


Figure 12. Northeast Anaerobic Cell Layer 2 Tube Readings

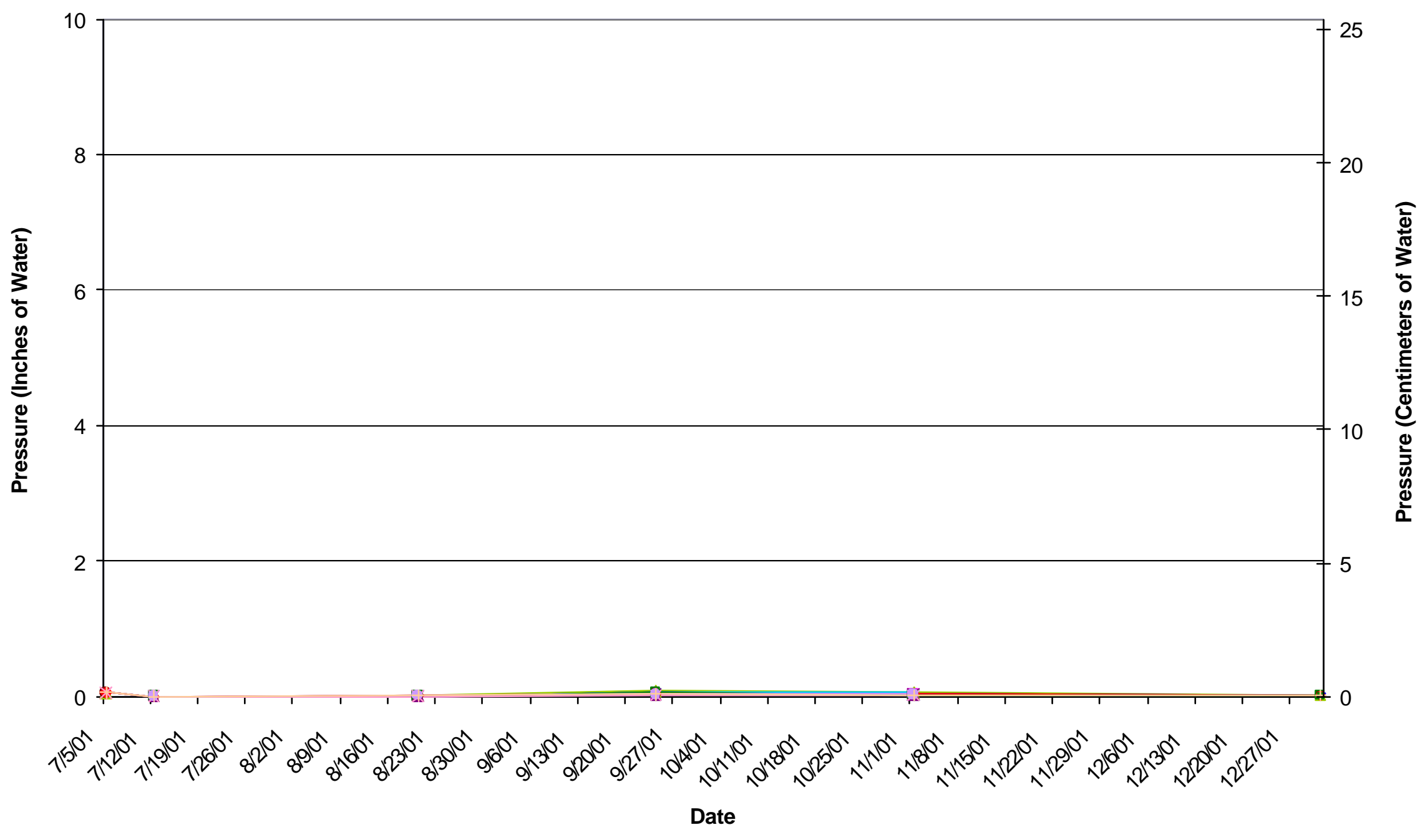

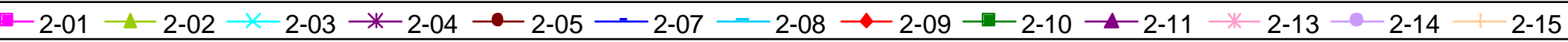


Figure 13. Northeast Anaerobic Cell Layer 3 Tube Readings

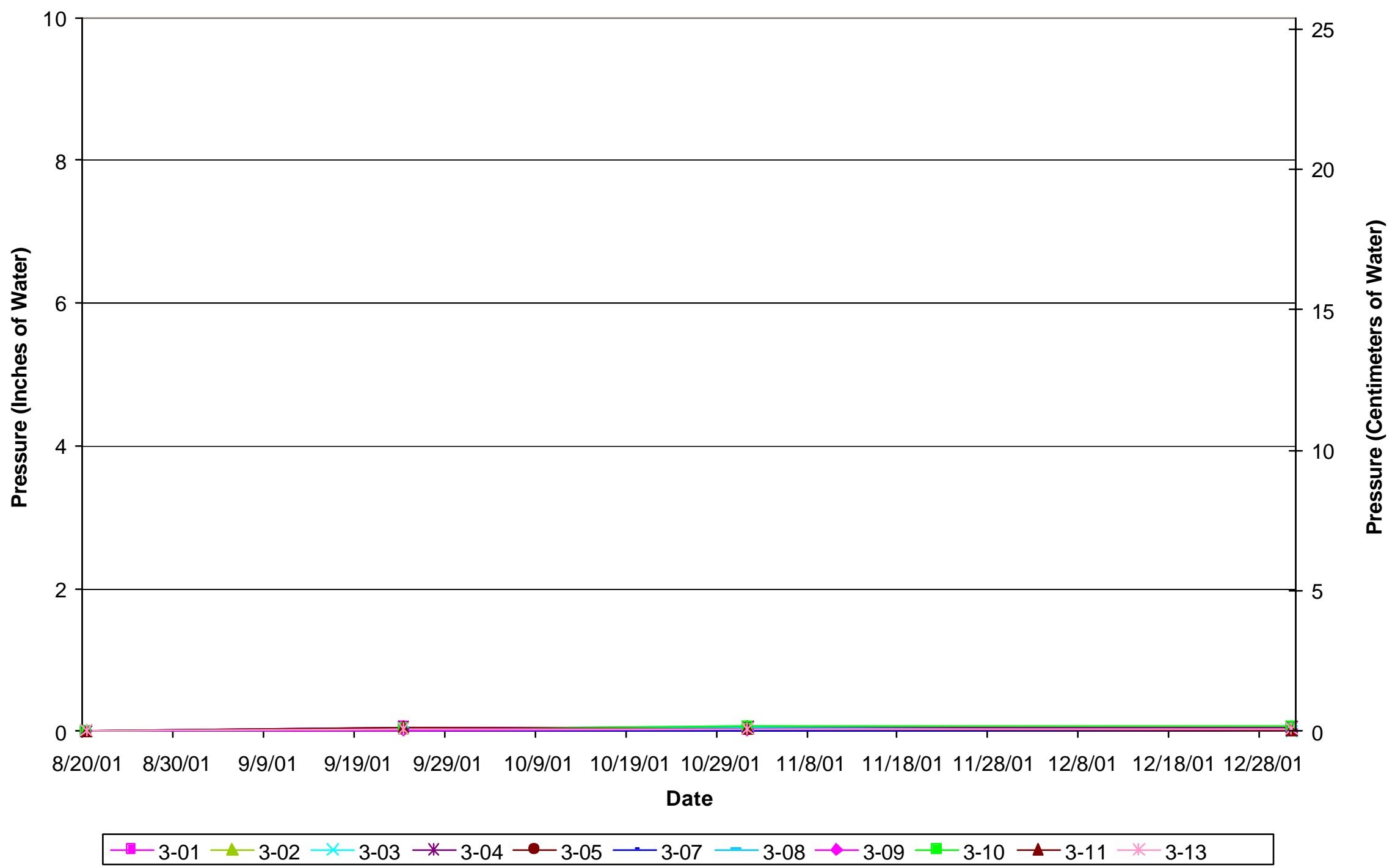


Table 8. Northeast Anaerobic Cell Base Layer Gas Compositions

\begin{tabular}{|c|c|c|c|c|c|c|c|c|c|c|c|c|c|c|c|c|c|c|c|c|}
\hline \multirow{3}{*}{\begin{tabular}{|c|} 
Sensor \\
Date Installed: \\
Date Covered $^{2}$ : \\
\end{tabular}} & \multicolumn{4}{|c|}{$0-36$} & \multicolumn{4}{|c|}{$0-37$} & \multicolumn{4}{|c|}{$0-38$} & \multicolumn{4}{|c|}{$0-39$} & \multicolumn{4}{|c|}{$0-40$} \\
\hline & \multicolumn{4}{|c|}{$7 / 28 / 00$} & \multicolumn{4}{|c|}{$\begin{array}{l}7 / 28 / 00 \\
2 / 16 / 01\end{array}$} & \multicolumn{4}{|c|}{$\begin{array}{l}7 / 28 / 00 \\
2 / 16 / 01\end{array}$} & \multicolumn{4}{|c|}{$\begin{array}{l}7 / 28 / 00 \\
2 / 16 / 01\end{array}$} & \multicolumn{4}{|c|}{$\begin{array}{l}7 / 28 / 00 \\
2 / 16 / 01 \\
\end{array}$} \\
\hline & $\% \mathrm{CH}_{4}$ & $\% \mathrm{CO}_{2}$ & $\% \mathrm{O}_{2}$ & $\%$ Balance $^{3}$ & $\% \mathrm{CH}_{4}$ & $\% \mathrm{CO}_{2}$ & $\% \mathrm{O}_{2}$ & $\%$ Balance & $\% \mathrm{CH}_{4}$ & $\% \mathrm{CO}_{2}$ & $\% \mathrm{O}_{2}$ & $\%$ Balance & $\% \mathrm{CH}_{4}$ & $\% \mathrm{CO}_{2}$ & $\% \mathrm{O}_{2}$ & $\%$ Balance & $\% \mathrm{CH}_{4}$ & $\% \mathrm{CO}_{2}$ & $\% \mathrm{O}_{2}$ & $\%$ Balance \\
\hline $\begin{array}{c}5 / 30 / 01 \\
7 / 3 / 01\end{array}$ & 21.6 & 55.6 & 0 & 22.4 & & & & & & & & & 18.9 & 57.6 & $\overline{0.4}$ & 22.8 & 38.5 & 59.3 & 0 & 2.2 \\
\hline $\begin{array}{c}7 / 10 / 01 \\
7 / 11 / 01 \\
8 / 22 / 01 \\
9 / 6 / 01 \\
9 / 21 / 01 \\
12 / 31 / 01\end{array}$ & 45.3 & 54.6 & 0 & 0 & 47.6 & 58.2 & 0 & 9.9 & 47.9 & 50.3 & 0.4 & 1.4 & $\begin{array}{l}40.4 \\
50.3 \\
52.9 \\
\\
35.5\end{array}$ & $\begin{array}{l}59.7 \\
\\
48.8 \\
47.1 \\
43.2\end{array}$ & $\begin{array}{c}0.1 \\
0 \\
0 \\
0.9\end{array}$ & $\begin{array}{c}0.7 \\
0 \\
0 \\
20.6\end{array}$ & 46.5 & 53.4 & 0 & 0 \\
\hline
\end{tabular}

\begin{tabular}{|c|c|c|c|c|c|c|c|c|c|c|c|c|c|c|c|c|c|c|c|c|}
\hline Sensor & \multicolumn{4}{|c|}{$0-41$} & \multicolumn{4}{|c|}{$0-42$} & \multicolumn{4}{|c|}{$0-43$} & \multicolumn{4}{|c|}{$0-44$} & \multicolumn{4}{|c|}{$0-45$} \\
\hline $\begin{array}{l}\text { Date Installed: } \\
\text { Date Covered: }\end{array}$ & & & $\begin{array}{l}28 / 00 \\
16 / 01\end{array}$ & & & & $\begin{array}{l}28 / 00 \\
/ 16 / 01\end{array}$ & & & & $\begin{array}{l}28 / 00 \\
2 / 2 / 01\end{array}$ & & & & $\begin{array}{l}28 / 00 \\
2 / 01\end{array}$ & & & & $\begin{array}{l}28 / 00 \\
2 / 01\end{array}$ & \\
\hline Date Monitored & $\% \mathrm{CH}_{4}$ & $\% \mathrm{CO}_{2}$ & $\% \mathrm{O}_{2}$ & $\%$ Balance & $\% \mathrm{CH}_{4}$ & $\% \mathrm{CO}_{2}$ & $\% \mathrm{O}_{2}$ & $\%$ Balance & $\% \mathrm{CH}_{4}$ & $\% \mathrm{CO}_{2}$ & $\% \mathrm{O}_{2}$ & $\%$ Balance & $\% \mathrm{CH}_{4}$ & $\% \mathrm{CO}_{2}$ & $\% \mathrm{O}_{2}$ & $\%$ Balance & $\% \mathrm{CH}_{4}$ & $\% \mathrm{CO}_{2}$ & $\% \mathrm{O}_{2}$ & $\%$ Balance \\
\hline $\begin{array}{c}5 / 30 / 01 \\
7 / 3 / 01 \\
7 / 10 / 01 \\
7 / 11 / 01 \\
8 / 22 / 01 \\
9 / 6 / 01 \\
9 / 21 / 01 \\
12 / 31 / 01\end{array}$ & $\begin{array}{l}31.5 \\
40.5\end{array}$ & $\begin{array}{l}56.5 \\
55.8\end{array}$ & 0 & $\begin{array}{l}11.6 \\
2.7\end{array}$ & 41.2 & 48.8 & 2 & 7.9 & 31.5 & 55.6 & 0 & 12.9 & $\begin{array}{l}28.8 \\
31.7 \\
\\
37.5 \\
39.2 \\
40.3 \\
13.7\end{array}$ & $\begin{array}{c}57.9 \\
59.1 \\
\\
55.8 \\
54.1 \\
55.8 \\
31\end{array}$ & $\begin{array}{l}0 \\
0 \\
\\
0 \\
0 \\
0 \\
0\end{array}$ & $\begin{array}{c}12.9 \\
9.4 \\
\\
604 \\
7.1 \\
3.3 \\
55.3\end{array}$ & 33.4 & 50.7 & 0.9 & 15.3 \\
\hline
\end{tabular}

\begin{tabular}{|c|c|c|c|c|c|c|c|c|c|c|c|c|c|c|c|c|c|c|c|c|}
\hline Sensor & \multicolumn{4}{|c|}{$0-46$} & \multicolumn{4}{|c|}{$0-47$} & \multicolumn{4}{|c|}{$0-48$} & \multicolumn{4}{|c|}{$0-49$} & \multicolumn{4}{|c|}{$0-50$} \\
\hline $\begin{array}{l}\text { Date Installed: } \\
\text { Date Covered: }\end{array}$ & & & $\begin{array}{l}28 / 00 \\
/ 2 / 01\end{array}$ & & & & $\begin{array}{l}/ 28 / 00 \\
2 / 2 / 01\end{array}$ & & & & $\begin{array}{l}28 / 00 \\
2 / 2 / 01\end{array}$ & & & & $\begin{array}{l}28 / 00 \\
/ 2 / 01\end{array}$ & & & & $\begin{array}{l}28 / 00 \\
2 / 01\end{array}$ & \\
\hline Date Monitored & $\% \mathrm{CH}_{4}$ & $\% \mathrm{CO}_{2}$ & $\% \mathrm{O}_{2}$ & $\%$ Balance & $\% \mathrm{CH}_{4}$ & $\% \mathrm{CO}_{2}$ & $\% \mathrm{O}_{2}$ & $\%$ Balance & $\% \mathrm{CH}_{4}$ & $\% \mathrm{CO}_{2}$ & $\% \mathrm{O}_{2}$ & $\%$ Balance & $\% \mathrm{CH}_{4}$ & $\% \mathrm{CO}_{2}$ & $\% \mathrm{O}_{2}$ & $\%$ Balance & $\% \mathrm{CH}_{4}$ & $\% \mathrm{CO}_{2}$ & $\% \mathrm{O}_{2}$ & $\%$ Balance \\
\hline $\begin{array}{c}5 / 30 / 01 \\
7 / 3 / 01 \\
7 / 10 / 01 \\
7 / 11 / 01 \\
8 / 22 / 01 \\
9 / 6 / 01 \\
12 / 31 / 01 \\
\end{array}$ & 45.3 & 54.4 & 0 & 0.4 & 25.4 & 53.7 & 0.3 & 21 & $\begin{array}{l}42.1 \\
10.6\end{array}$ & $\begin{array}{l}56.2 \\
28.2\end{array}$ & $\begin{array}{c}0 \\
2.1\end{array}$ & $\begin{array}{c}1.7 \\
58.7\end{array}$ & 36.1 & 57.3 & 0 & 6.3 & $\begin{array}{l}31.1 \\
33.9\end{array}$ & $\begin{array}{l}53.4 \\
53.1\end{array}$ & $\begin{array}{c}0 \\
1.8\end{array}$ & $\begin{array}{l}15.5 \\
11.2\end{array}$ \\
\hline
\end{tabular}

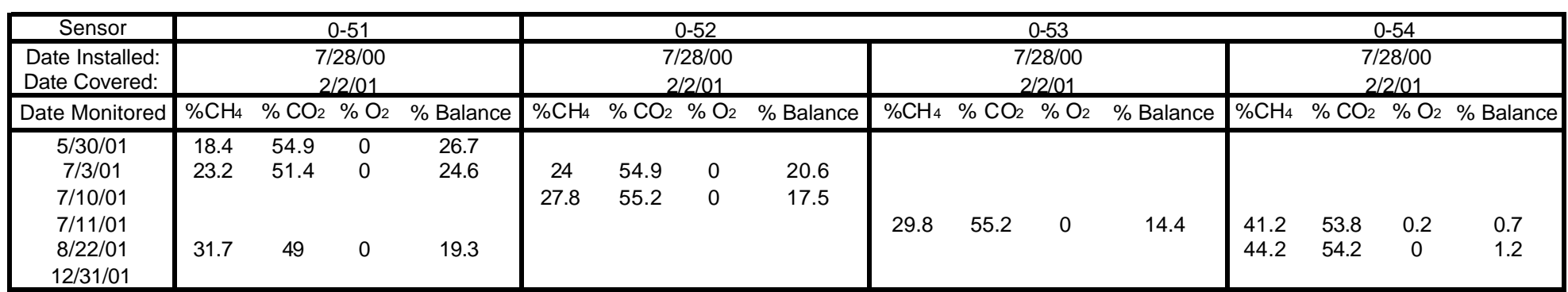

Sensor nomenclature: Instrumentation layer \# the senor is located - Sensor \# on that layer

${ }^{2}$ Date covered refers to the date waste was placed over the sensor

${ }^{3}$ Balance is assumed to be nitrogen 
YOLO COUNTY CENTRAL LANDFILL

EPA PROJECT XL

FULL SCALE BIOREACTOR TECHNICAL PROGRESS REPORT

Table 9. Northeast Anaerobic Cell Layer 1 Gas Compositions

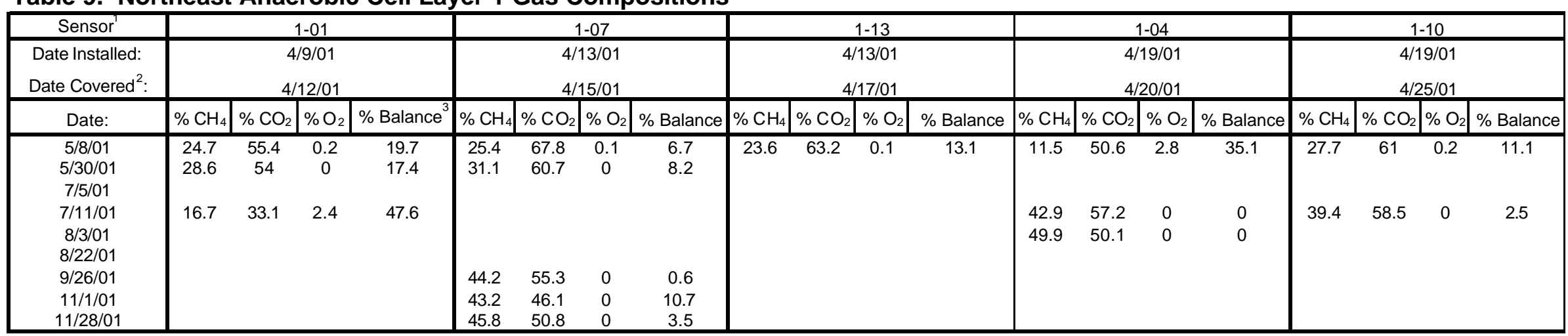

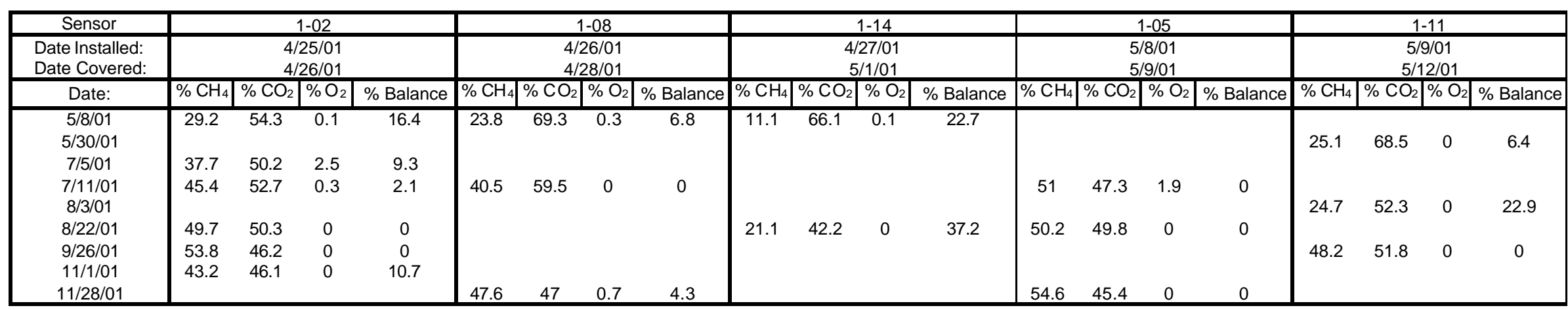

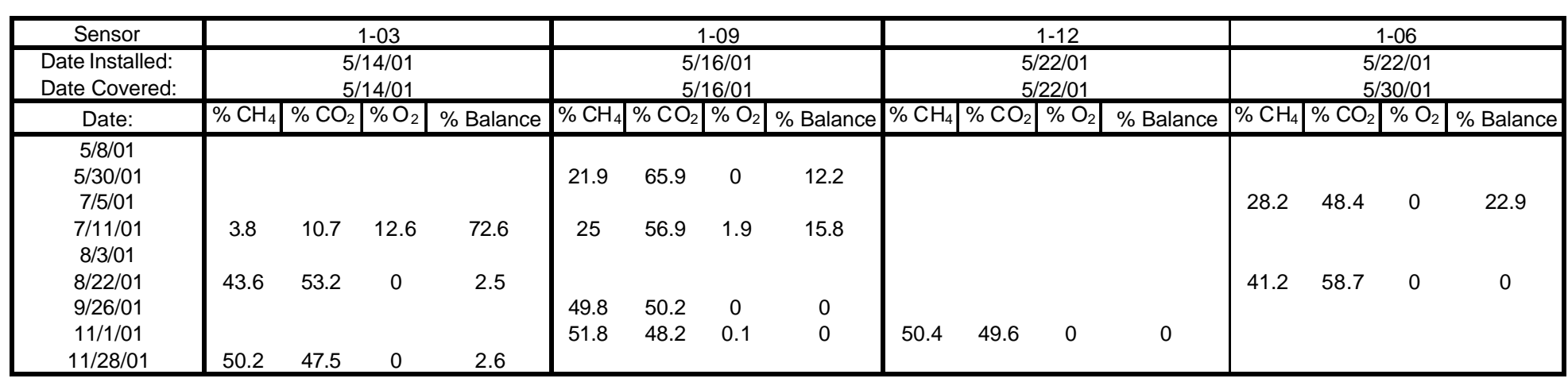

*Table Is Organized Based On Cover Dates

${ }^{1}$ Sensor nomenclature: Instrumentation layer \# the senor is located - Sensor \# on that layer

${ }^{2}$ Date covered refers to the date waste was placed over the sensor

Balance is assumed to be nitrogen

*Gas Compositions measured by the GEM- 500 by Landtec 
Table 10. Northeast Anaerobic Cell Layer 2 Gas Compositions (Full Scale Project)

\begin{tabular}{|c|c|c|c|c|c|c|c|c|c|c|c|c|c|c|c|c|c|c|c|c|}
\hline Sensor & \multicolumn{4}{|c|}{$2-13$} & \multicolumn{4}{|c|}{$2-07$} & \multicolumn{4}{|c|}{$2-01$} & \multicolumn{4}{|c|}{$2-04$} & \multicolumn{4}{|c|}{$2-10$} \\
\hline $\begin{array}{l}\text { Date Installed: } \\
\text { Date Covered }\end{array}$ & \multicolumn{4}{|c|}{$\begin{array}{l}6 / 1 / 01 \\
6 / 1 / 01 \\
\end{array}$} & \multicolumn{4}{|c|}{$\begin{array}{l}6 / 1 / 01 \\
6 / 5 / 01\end{array}$} & \multicolumn{4}{|c|}{$\begin{array}{l}6 / 1 / 01 \\
6 / 6 / 01 \\
\end{array}$} & \multicolumn{4}{|c|}{$\begin{array}{l}6 / 7 / 01 \\
6 / 8 / 01 \\
\end{array}$} & \multicolumn{4}{|c|}{$\begin{array}{l}6 / 7 / 01 \\
6 / 8 / 01 \\
\end{array}$} \\
\hline Date: & $\% \mathrm{CH}_{4}$ & $\% \mathrm{CO}_{2}$ & $\% \mathrm{O}_{2}$ & $\%$ Balance $^{3}$ & $\% \mathrm{CH}_{4}$ & $\% \mathrm{CO}_{2}$ & $\% \mathrm{O}_{2}$ & $\%$ Balance & $\% \mathrm{CH}_{4}$ & $\% \mathrm{CO}_{2}$ & $\% \mathrm{O}_{2}$ & $\%$ Balance & $\% \mathrm{CH}_{4}$ & $\% \mathrm{CO}_{2}$ & $\% \mathrm{O}_{2}$ & $\%$ Balance & $\% \mathrm{CH}_{4}$ & $\% \mathrm{CO}_{2}$ & $\% \mathrm{O}_{2}$ & $\%$ Balance \\
\hline $\begin{array}{c}6 / 11 / 01 \\
7 / 2 / 01 \\
7 / 12 / 01 \\
8 / 22 / 01 \\
9 / 26 / 01 \\
11 / 1 / 01 \\
11 / 28 / 01\end{array}$ & 0 & 0.4 & 20.1 & 79.6 & 0.4 & 4.3 & 18.1 & 78.3 & $\begin{array}{c}0.7 \\
\\
22.8 \\
35.2 \\
39.5\end{array}$ & $\begin{array}{l}5.2 \\
4.5 \\
\\
37.1 \\
42.2 \\
46.6 \\
\end{array}$ & $\begin{array}{c}17.6 \\
\\
1.8 \\
0.5 \\
0\end{array}$ & $\begin{array}{c}77.9 \\
77 \\
\\
38.7 \\
22.2 \\
13.9 \\
\end{array}$ & $\begin{array}{c}0.1 \\
0.5 \\
\\
37 \\
21.2\end{array}$ & $\begin{array}{c}4.8 \\
13.2 \\
\\
56.6 \\
31.2\end{array}$ & $\begin{array}{c}15.9 \\
18.4 \\
0 \\
7.8\end{array}$ & $\begin{array}{c}79.1 \\
77.9 \\
\\
6.3 \\
39.8\end{array}$ & $\begin{array}{l}3.1 \\
1.6\end{array}$ & $\begin{array}{l}31.9 \\
24.1\end{array}$ & $\begin{array}{l}0 \\
0\end{array}$ & $\begin{array}{l}64.9 \\
74.4\end{array}$ \\
\hline
\end{tabular}

\begin{tabular}{|c|c|c|c|c|c|c|c|c|c|c|c|c|c|c|c|c|}
\hline Sensor & \multicolumn{4}{|c|}{$2-02$} & \multicolumn{4}{|c|}{$2-08$} & \multicolumn{4}{|c|}{$2-14$} & \multicolumn{4}{|c|}{$2-05$} \\
\hline $\begin{array}{l}\text { Date Installed: } \\
\text { Date Covered: }\end{array}$ & \multicolumn{4}{|c|}{$\begin{array}{l}6 / 19 / 01 \\
6 / 20 / 01\end{array}$} & \multicolumn{4}{|c|}{$\begin{array}{l}6 / 19 / 01 \\
6 / 20 / 01\end{array}$} & \multicolumn{4}{|c|}{$\begin{array}{l}6 / 19 / 01 \\
6 / 20 / 01\end{array}$} & \multicolumn{4}{|c|}{$\begin{array}{l}6 / 26 / 01 \\
6 / 27 / 01\end{array}$} \\
\hline Date: & $\% \mathrm{CH}_{4}$ & $\% \mathrm{CO}_{2}$ & $\% \mathrm{O}_{2}$ & $\%$ Balance & $\% \mathrm{CH}_{4}$ & $\% \mathrm{CO}_{2}$ & $\% \mathrm{O}_{2}$ & $\%$ Balance & $\% \mathrm{CH}_{4}$ & $\% \mathrm{CO}_{2}$ & $\% \mathrm{O}_{2}$ & $\%$ Balance & $\% \mathrm{CH}_{4}$ & $\% \mathrm{CO}_{2}$ & $\% \mathrm{O}_{2}$ & $\%$ Balance \\
\hline $\begin{array}{c}6 / 11 / 01 \\
7 / 2 / 01 \\
7 / 12 / 01 \\
8 / 22 / 01 \\
9 / 26 / 01 \\
11 / 1 / 01 \\
11 / 28 / 01\end{array}$ & $\begin{array}{l}6.8 \\
0.1 \\
0.5\end{array}$ & $\begin{array}{l}41.6 \\
2.5 \\
3.1\end{array}$ & $\begin{array}{c}0 \\
18.8 \\
18.7\end{array}$ & $\begin{array}{l}57.7 \\
78.7 \\
77.6\end{array}$ & $\begin{array}{c}0.1 \\
16.6\end{array}$ & $\begin{array}{c}3.1 \\
46.7\end{array}$ & $\begin{array}{l}18.3 \\
2.3\end{array}$ & $\begin{array}{l}78.4 \\
34.1\end{array}$ & 0 & 1.1 & 20.1 & 78.9 & $\begin{array}{l}3.6 \\
30\end{array}$ & $\begin{array}{r}37.8 \\
52.6\end{array}$ & 3.5 & 55.5 \\
\hline
\end{tabular}

\begin{tabular}{|c|c|c|c|c|c|c|c|c|c|c|c|c|c|c|c|c|}
\hline Sensor & \multicolumn{4}{|c|}{$2-11$} & \multicolumn{4}{|c|}{$2-03$} & \multicolumn{4}{|c|}{$2-09$} & \multicolumn{4}{|c|}{$2-15$} \\
\hline Date Installed: & \multicolumn{4}{|c|}{$6 / 26 / 01$} & \multicolumn{4}{|c|}{$7 / 5 / 01$} & \multicolumn{4}{|c|}{$7 / 5 / 01$} & \multicolumn{4}{|c|}{$7 / 5 / 01$} \\
\hline Date Covered: & \multicolumn{4}{|c|}{$6 / 27 / 01$} & \multicolumn{4}{|c|}{ 7/6/01 } & \multicolumn{4}{|c|}{$7 / 6 / 01$} & \multicolumn{4}{|c|}{$7 / 6 / 01$} \\
\hline Date: & $\% \mathrm{CH}_{4}$ & $\% \mathrm{CO}_{2}$ & $\% \mathrm{O}_{2}$ & $\%$ Balance & $\% \mathrm{CH}_{4}$ & $\% \mathrm{CO}_{2}$ & $\% \mathrm{O}_{2}$ & $\%$ Balance & $\% \mathrm{CH}_{4}$ & $\% \mathrm{CO}_{2}$ & $\% \mathrm{O}_{2}$ & $\%$ Balance & $\% \mathrm{CH}_{4}$ & $\% \mathrm{CO}_{2}$ & $\% \mathrm{O}_{2}$ & $\%$ Balance \\
\hline $\begin{array}{c}6 / 11 / 01 \\
7 / 2 / 01 \\
7 / 12 / 01 \\
8 / 22 / 01 \\
9 / 26 / 01 \\
11 / 1 / 01 \\
11 / 28 / 01\end{array}$ & 0.7 & 6.7 & 17.1 & 75 & 1.6 & 21.3 & 9.9 & 67.5 & $\begin{array}{c}0 \\
0.4 \\
21 \\
24.3\end{array}$ & $\begin{array}{c}3.5 \\
5.4 \\
55.4 \\
44.9\end{array}$ & $\begin{array}{c}18.8 \\
18.1 \\
0.2 \\
0\end{array}$ & $\begin{array}{c}77.6 \\
76.3 \\
23.6 \\
31\end{array}$ & 0 & 1.1 & 20.6 & 78.3 \\
\hline
\end{tabular}

*Table Is Organized Based On Cover Dates

Sensor nomenclature: Instrumentation layer \# the senor is located - Sensor \# on that layer

${ }^{2}$ Date covered refers to the date waste was placed over the sensor

Balance is assumed to be nitrogen

${ }^{*}$ Gas Compositions measured by the GEM-500 by Landtec 
Table 11. Northeast Anaerobic Cell Layer 3 Gas Compositions

\begin{tabular}{|c|c|c|c|c|c|c|c|c|c|c|c|c|c|c|c|c|c|c|c|c|}
\hline Sensors & \multicolumn{4}{|c|}{ 3-01 } & \multicolumn{4}{|c|}{ 3-09 } & \multicolumn{4}{|c|}{$3-02$} & \multicolumn{4}{|c|}{$3-05$} & \multicolumn{4}{|c|}{$3-10$} \\
\hline Date Installed: & \multirow{2}{*}{\multicolumn{4}{|c|}{$\begin{array}{l}7 / 13 / 01 \\
7 / 17 / 01\end{array}$}} & \multirow{2}{*}{\multicolumn{4}{|c|}{$\begin{array}{l}7 / 17 / 01 \\
7 / 19 / 01\end{array}$}} & \multirow{2}{*}{\multicolumn{4}{|c|}{$\begin{array}{l}7 / 20 / 01 \\
7 / 23 / 01\end{array}$}} & \multirow{2}{*}{\multicolumn{4}{|c|}{$\begin{array}{l}7 / 27 / 01 \\
7 / 29 / 01\end{array}$}} & \multirow{2}{*}{\multicolumn{4}{|c|}{$\begin{array}{l}7 / 27 / 01 \\
7 / 29 / 01\end{array}$}} \\
\hline Date Covered ${ }^{2}$ : & & & & & & & & & & & & & & & & & & & & \\
\hline Date: & $\% \mathrm{CH}_{4}$ & $\% \mathrm{CO}_{2}$ & $\% \mathrm{O}_{2}$ & \%Balance & $\% \mathrm{CH}_{4}$ & $\% \mathrm{CO}_{2}$ & $\% \mathrm{O}_{2}$ & \%Balance & $\% \mathrm{CH}_{4}$ & $\% \mathrm{CO}_{2}$ & $\% \mathrm{O}_{2}$ & \%Balance & $\% \mathrm{CH}_{4}$ & $\% \mathrm{CO}_{2}$ & $\% \mathrm{O}_{2}$ & \%Balance & $\% \mathrm{CH}_{4}$ & $\% \mathrm{CO}_{2}$ & $\% \mathrm{O}_{2}$ & $\%$ Balance \\
\hline $9 / 21 / 01$ & 31.6 & 30.2 & $\overline{0}$ & 17.7 & 27.5 & 61.2 & $\overline{0}$ & $\overline{11.5}$ & 19.3 & 62.6 & 0 & 18.1 & 13 & 44.5 & 1.8 & 40.9 & & & & \\
\hline 9/26/01 & 28.7 & 48.6 & 0 & 13.2 & 26 & 57.8 & 0 & 16.1 & & & & & 20.8 & 53 & 0 & 25.8 & & & & \\
\hline $11 / 1 / 01$ & 36.9 & 52 & 0 & 10 & 24.4 & 50.2 & 0 & 25.3 & & & & & & & & & 23.7 & 57 & 0 & 20.3 \\
\hline $11 / 28 / 01$ & 45.1 & 50.4 & 0 & 4.4 & & & & & 19.6 & 55.1 & 0 & 24.5 & & & & & 19.3 & 48 & 0 & 32.7 \\
\hline
\end{tabular}

${ }_{1}^{*}$ Table Is Organized Based On Cover Dates

${ }^{1}$ Sensor nomenclature: Instrumentation layer \# the senor is located - Sensor \# on that layer

${ }_{3}^{2}$ Date covered refers to the date waste was placed over the sensor

${ }^{3}$ Balance is assumed to be nitrogen 


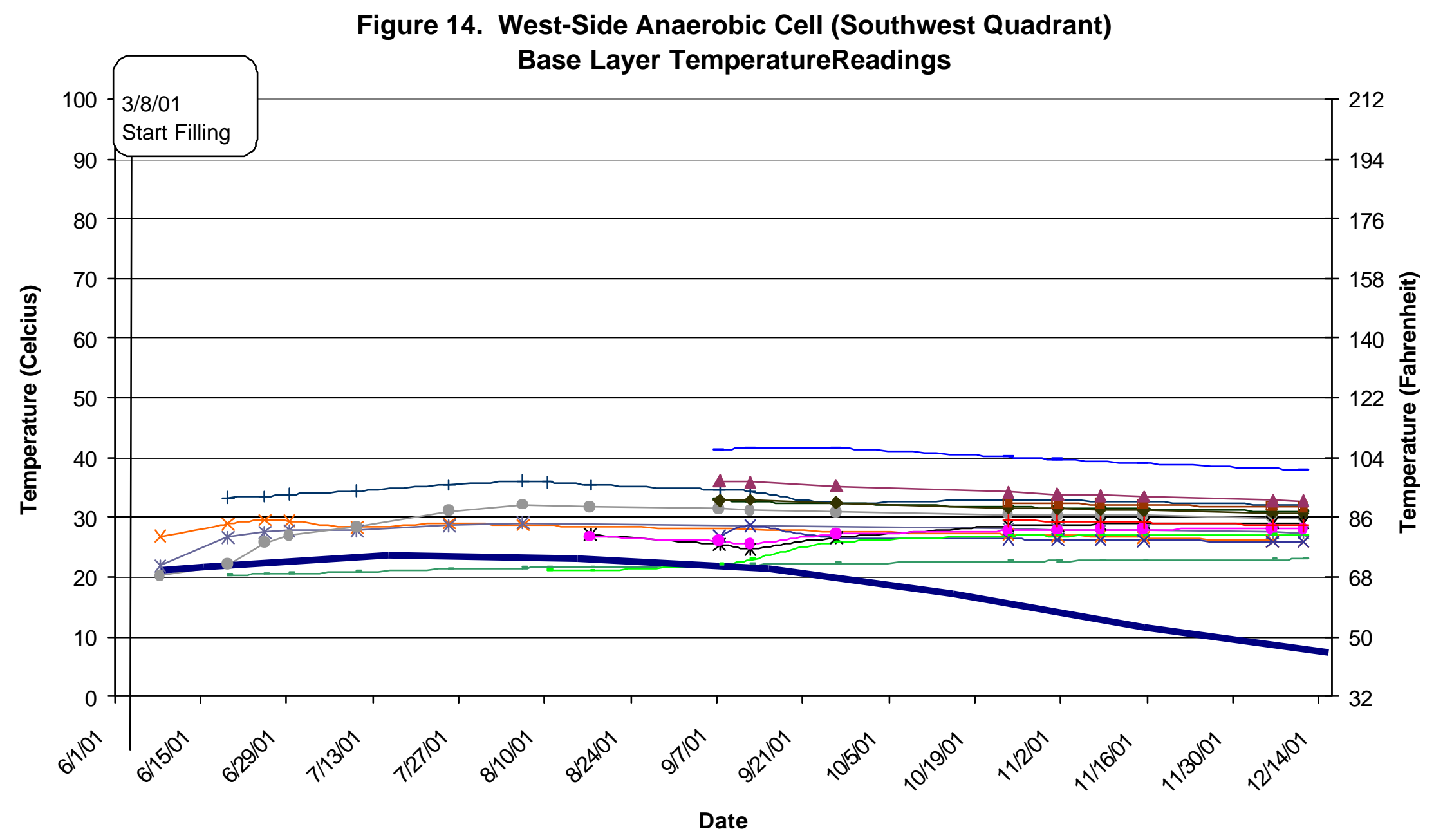

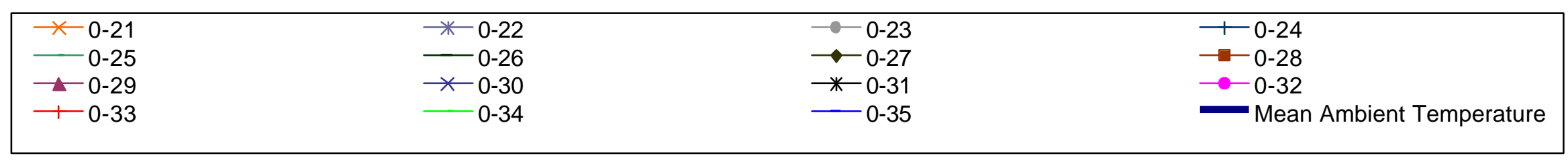


Figure 15. West-Side Anaerobic Cell (Northwest Quadrant)

Base Layer Temperature Readings

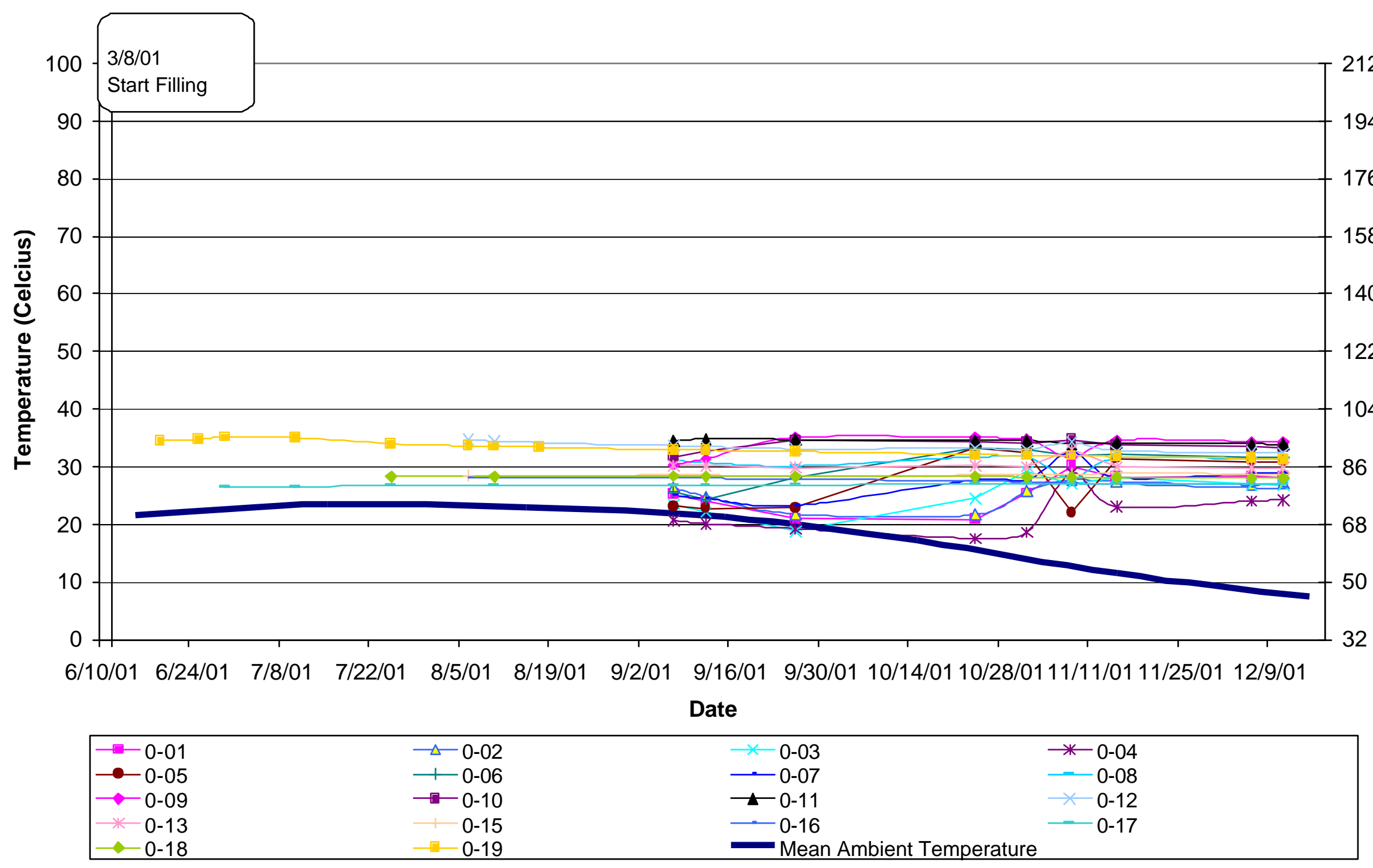


Figure 16. West-Side Anaerobic Cell Base Layer Moisture Readings

(PVC Moisture Sensors)

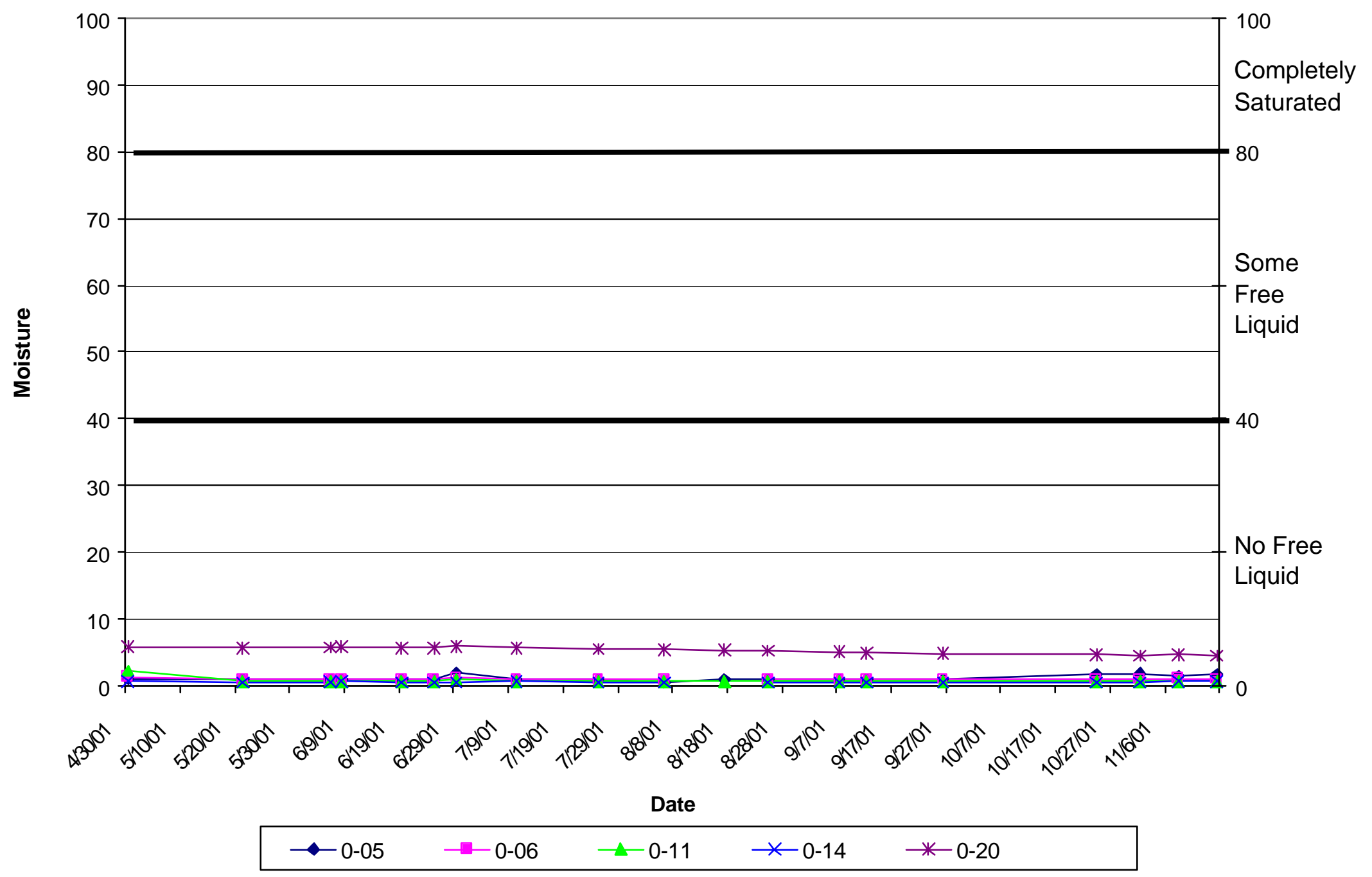


Figure 17. West-Side Anaerobic Cell (Northwest Quadrant) Base Layer Tube Readings

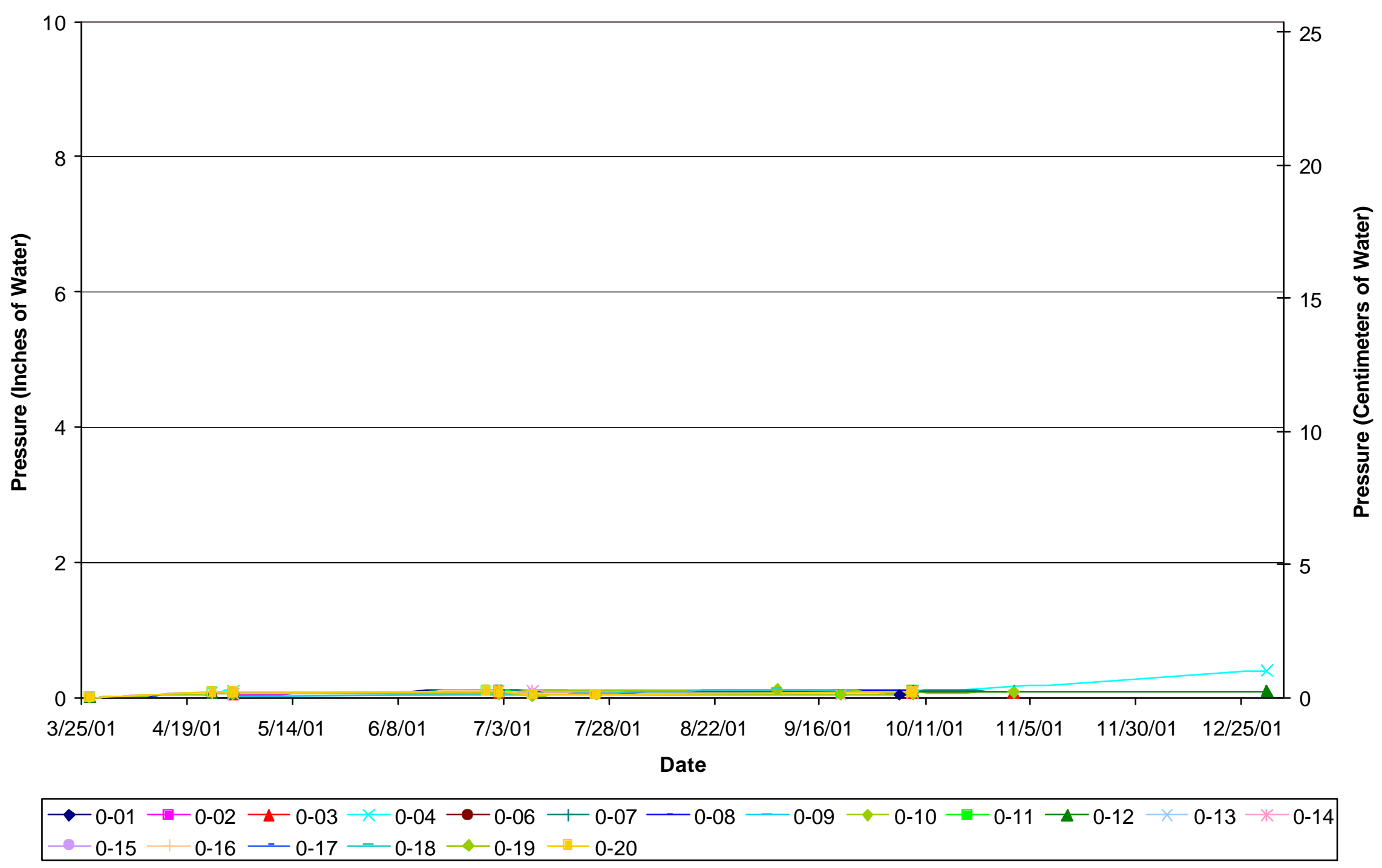




\section{Figure 18. West-Side Anaerobic Cell (Southwest Quadrant) Base Layer Tube Readings}

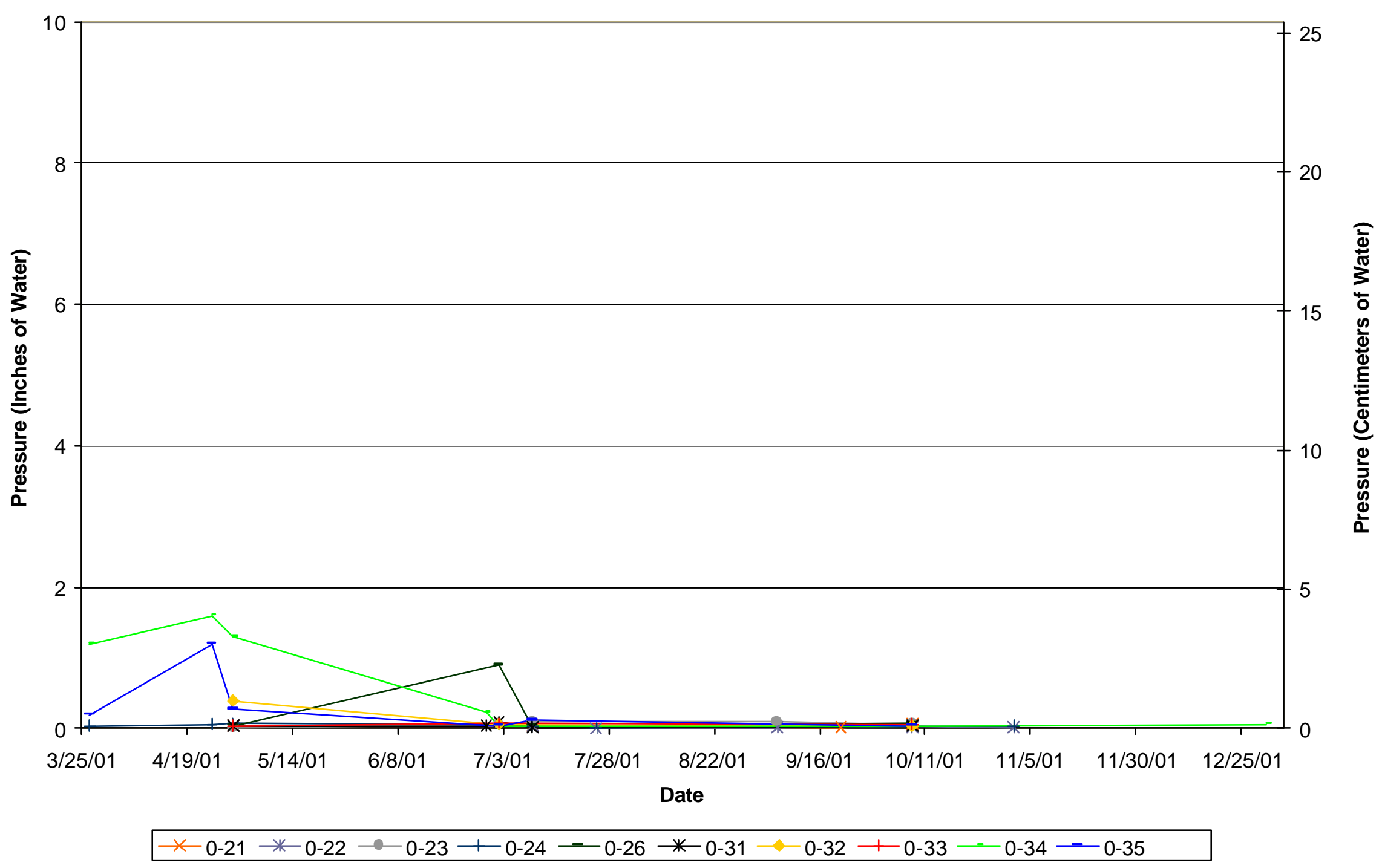


Table 12. West-Side Anaerobic Cell Base Layer Gas Compositions

\begin{tabular}{|c|c|c|c|c|c|c|c|c|c|c|c|c|c|c|c|c|c|c|c|c|}
\hline Sensor & \multicolumn{4}{|c|}{$0-04$} & \multicolumn{4}{|c|}{$0-12$} & \multicolumn{4}{|c|}{$0-16$} & \multicolumn{4}{|c|}{$0-17$} & \multicolumn{4}{|c|}{$0-19$} \\
\hline $\begin{array}{l}\text { Date Installed: } \\
\text { Date Covered }^{2} \text { : }\end{array}$ & \multicolumn{4}{|c|}{$10 / 9 / 00$} & \multicolumn{4}{|c|}{$10 / 9 / 00$} & \multicolumn{4}{|c|}{$\begin{array}{l}10 / 9 / 00 \\
6 / 21 / 01\end{array}$} & \multicolumn{4}{|c|}{$\begin{array}{l}10 / 9 / 00 \\
6 / 18 / 01 \\
\end{array}$} & \multicolumn{4}{|c|}{$\begin{array}{l}10 / 9 / 00 \\
6 / 18 / 01 \\
\end{array}$} \\
\hline Date Monitored & $\% \mathrm{CH}_{4}$ & $\% \mathrm{CO}_{2}$ & $\% \mathrm{O}_{2}$ & $\%$ Balance $^{3}$ & $\% \mathrm{CH}_{4}$ & $\% \mathrm{CO}_{2}$ & $\% \mathrm{O}_{2}$ & $\%$ Balance $^{3}$ & $\% \mathrm{CH}_{4}$ & $\% \mathrm{CO}_{2}$ & $\% \mathrm{O}_{2}$ & $\%$ Balance $^{3}$ & $\% \mathrm{CH}_{4}$ & $\% \mathrm{CO}_{2}$ & $\% \mathrm{O}_{2}$ & $\%$ Balance & $\% \mathrm{CH}_{4}$ & $\% \mathrm{CO}_{2}$ & $\% \mathrm{O}_{2}$ & $\%$ Balance \\
\hline $\begin{array}{c}7 / 3 / 01 \\
7 / 10 / 01 \\
8 / 21 / 01 \\
9 / 6 / 01 \\
9 / 21 / 01 \\
12 / 31 / 01\end{array}$ & 18.6 & 57 & 0.6 & 24 & 20 & 50.8 & 0 & 29.2 & $\begin{array}{l}11.5 \\
19.3\end{array}$ & $\begin{array}{l}33.5 \\
36.3\end{array}$ & $\begin{array}{l}0 \\
0\end{array}$ & $\begin{array}{l}55.2 \\
44.4\end{array}$ & $\begin{array}{l}7.2 \\
5.4\end{array}$ & $\begin{array}{l}34.7 \\
30.7\end{array}$ & $\begin{array}{c}0 \\
0.1\end{array}$ & $\begin{array}{l}58.1 \\
63.8\end{array}$ & $\begin{array}{c}7.1 \\
25.1 \\
46.6\end{array}$ & $\begin{array}{r}22.6 \\
40.5 \\
41.3\end{array}$ & $\begin{array}{c}9.9 \\
0 \\
0\end{array}$ & $\begin{array}{l}60.2 \\
34.3 \\
12.2\end{array}$ \\
\hline
\end{tabular}

\begin{tabular}{|c|c|c|c|c|c|c|c|c|c|c|c|c|c|c|c|c|c|c|c|c|}
\hline Sensor & \multicolumn{4}{|c|}{$0-20$} & \multicolumn{4}{|c|}{$0-21$} & \multicolumn{4}{|c|}{$0-23$} & \multicolumn{4}{|c|}{$0-25$} & \multicolumn{4}{|c|}{$0-34$} \\
\hline $\begin{array}{l}\text { Date Installed: } \\
\text { Date Covered: }\end{array}$ & \multicolumn{4}{|c|}{$\begin{array}{l}10 / 9 / 00 \\
6 / 18 / 01\end{array}$} & \multicolumn{4}{|c|}{$\begin{array}{c}10 / 25 / 00 \\
5 / 24 / 01\end{array}$} & \multicolumn{4}{|c|}{$\begin{array}{c}10 / 25 / 00 \\
6 / 1 / 01\end{array}$} & \multicolumn{4}{|c|}{$\begin{array}{c}10 / 11 / 00 \\
6 / 26 / 01\end{array}$} & \multicolumn{4}{|c|}{$\begin{array}{c}10 / 11 / 00 \\
9 / 20 / 01\end{array}$} \\
\hline Date Monitored & $\% \mathrm{CH}_{4}$ & $\% \mathrm{CO}_{2}$ & $\% \mathrm{O}_{2}$ & $\%$ Balance & $\% \mathrm{CH}_{4}$ & $\% \mathrm{CO}_{2}$ & $\% \mathrm{O}_{2}$ & $\%$ Balance & $\% \mathrm{CH}_{4}$ & $\% \mathrm{CO}_{2}$ & $\% \mathrm{O}_{2}$ & $\%$ Balance & $\% \mathrm{CH}_{4}$ & $\% \mathrm{CO}_{2}$ & $\% \mathrm{O}_{2}$ & $\%$ Balance & $\% \mathrm{CH}_{4}$ & $\% \mathrm{CO}_{2}$ & $\% \mathrm{O}_{2}$ & $\%$ Balance \\
\hline $\begin{array}{c}7 / 3 / 01 \\
7 / 10 / 01 \\
7 / 11 / 01 \\
8 / 21 / 01 \\
9 / 21 / 01 \\
12 / 31 / 01\end{array}$ & $\begin{array}{r}12.6 \\
42.2\end{array}$ & $\begin{array}{l}32.7 \\
40.3\end{array}$ & $\begin{array}{l}6 \\
0\end{array}$ & $\begin{array}{l}48.5 \\
34.3\end{array}$ & $\begin{array}{l}2.9 \\
5.3\end{array}$ & $\begin{array}{c}23 \\
30.2\end{array}$ & $\begin{array}{l}2 \\
0\end{array}$ & $\begin{array}{c}71.5 \\
64\end{array}$ & 8.9 & 39.6 & & 51.2 & $\begin{array}{c}9.8 \\
25.6\end{array}$ & $\begin{array}{l}30.6 \\
41.6\end{array}$ & 4.5 & $\begin{array}{l}55.4 \\
32.6\end{array}$ & 16.2 & 53.9 & 0.3 & 29.3 \\
\hline
\end{tabular}

${ }^{1}$ Sensor nomenclature: Instrumentation layer \# the senor is located - Sensor \# on that layer

${ }_{3}^{2}$ Date covered refers to the date waste was placed over the sensor

${ }^{3}$ Balance is assumed to be nitrogen

*Gas Compositions measured by the GEM-500 by Landtec 
Figure 19. Southeast Quadrant Anaerobic Base Liner Temperature Readings

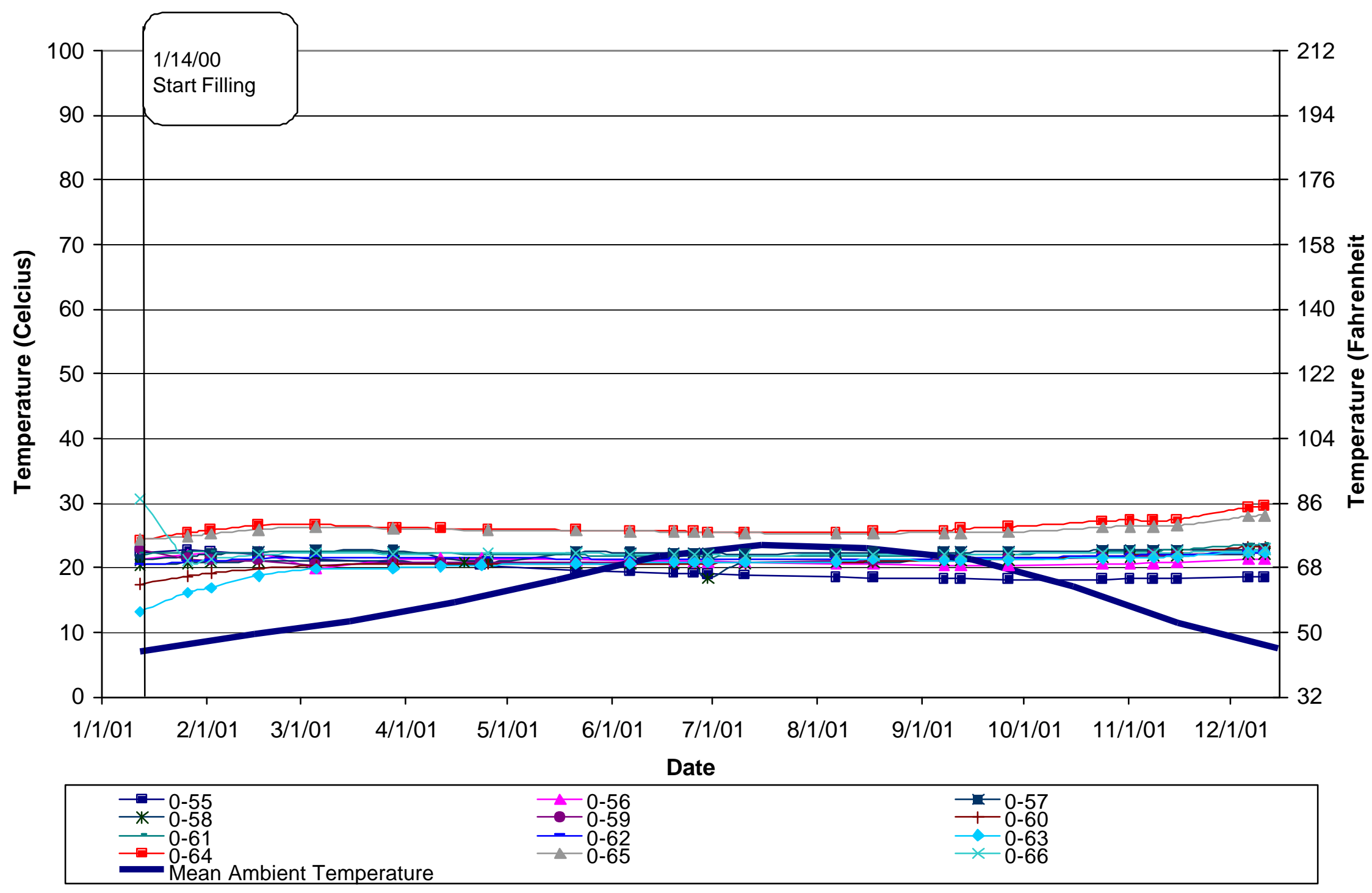


Figure 20. Aerobic Cell Layer 0 Temperature Readings

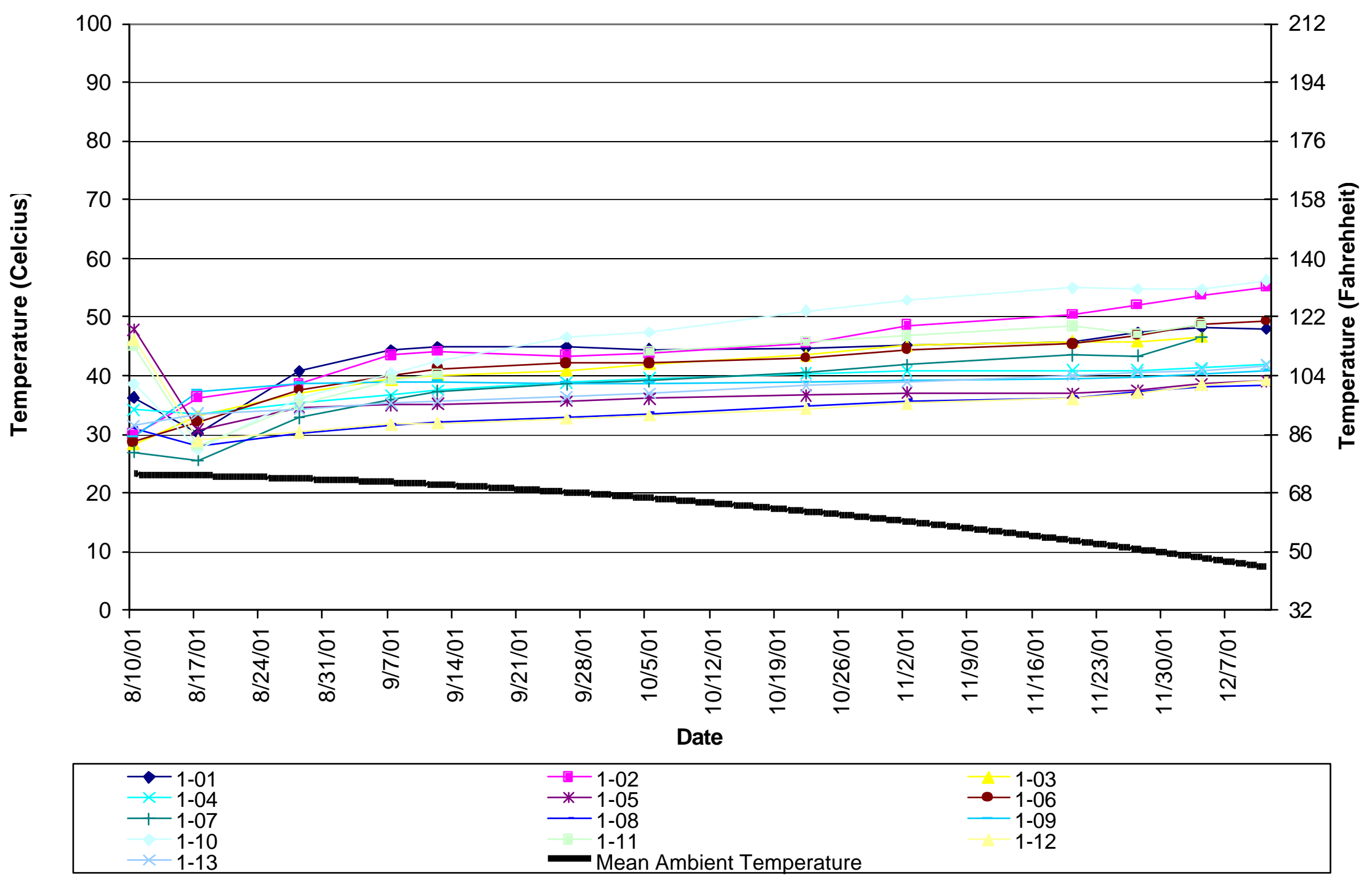


Figure 21. Aerobic Cell Layer 0.5 Temperature Readings

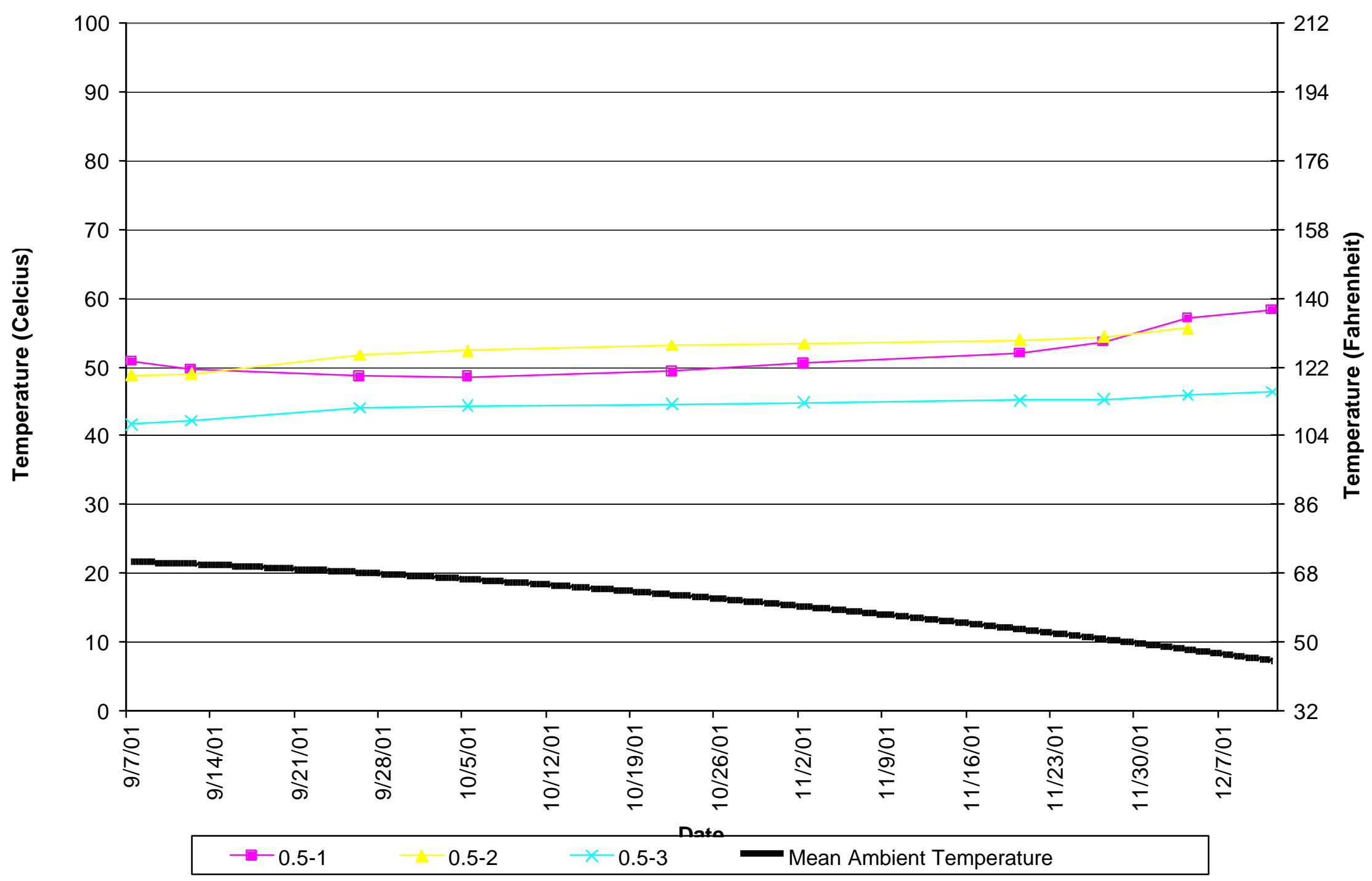


Figure 22. Aerobic Cell Layer 1 Temperature Readings

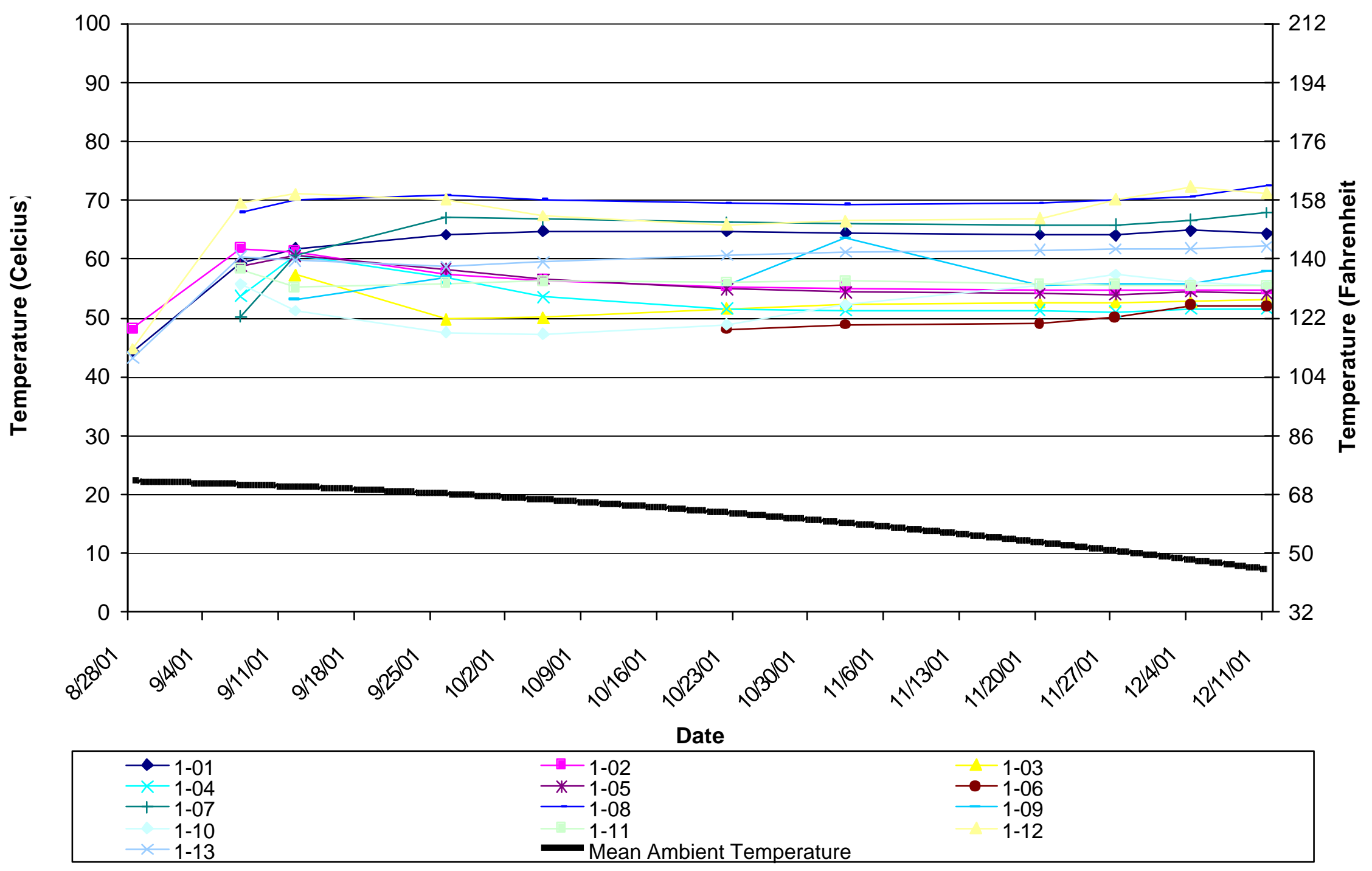


Figure 23. Aerobic Cell Layer 2 Temperature Readings

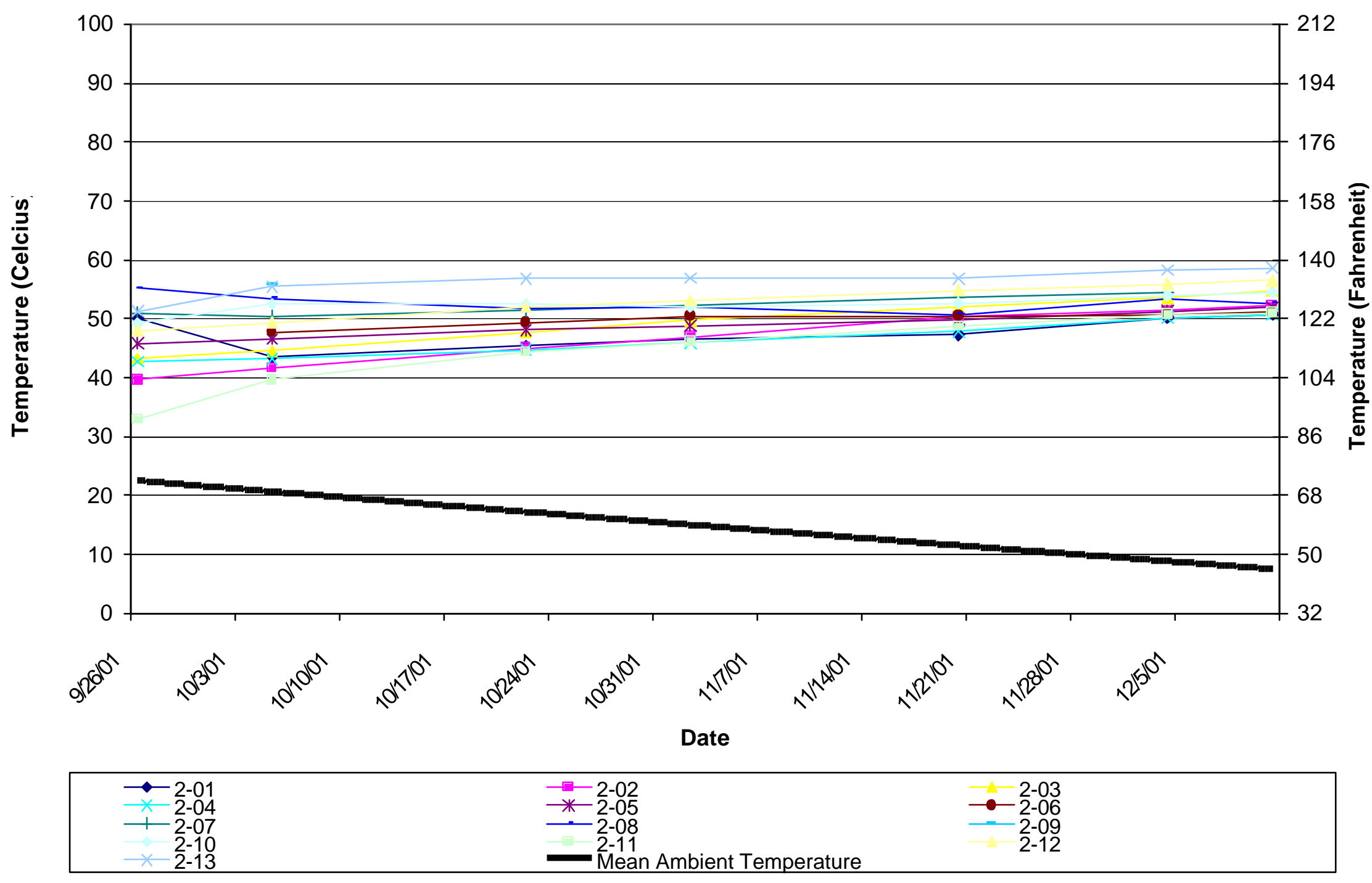




\section{Figure 24. Southeast Quadrant Anaerobic Base Liner Moisture Readings} (PVC Moisture Sensor)

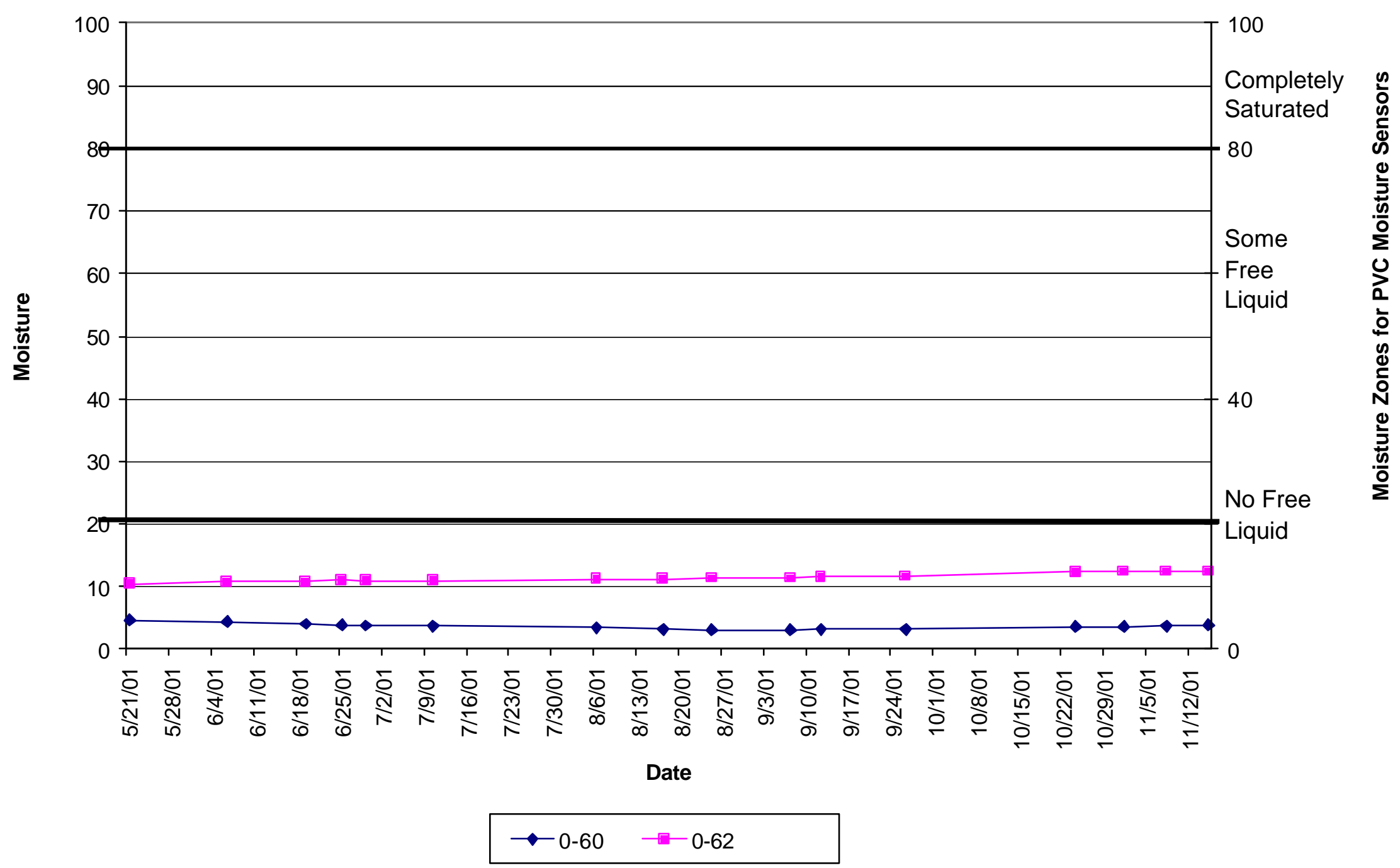


Figure 25. Aerobic Cell Aerobic Layer 0 Moisture Readings (PVC Moisture Sensors)

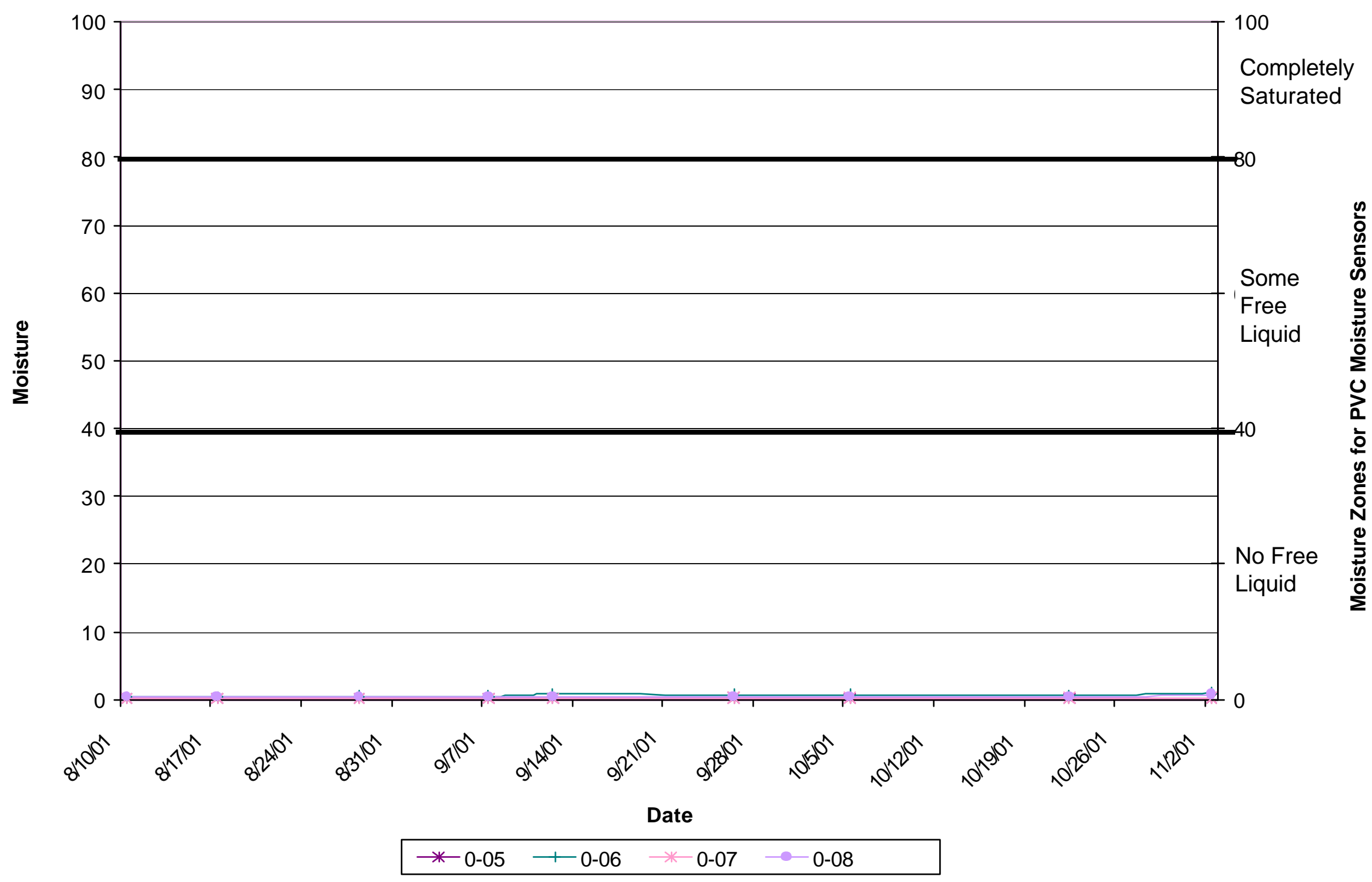


Figure 26. Aerobic Cell Layer 0.5 Moisture Readings (PVC Moisture Sensors)

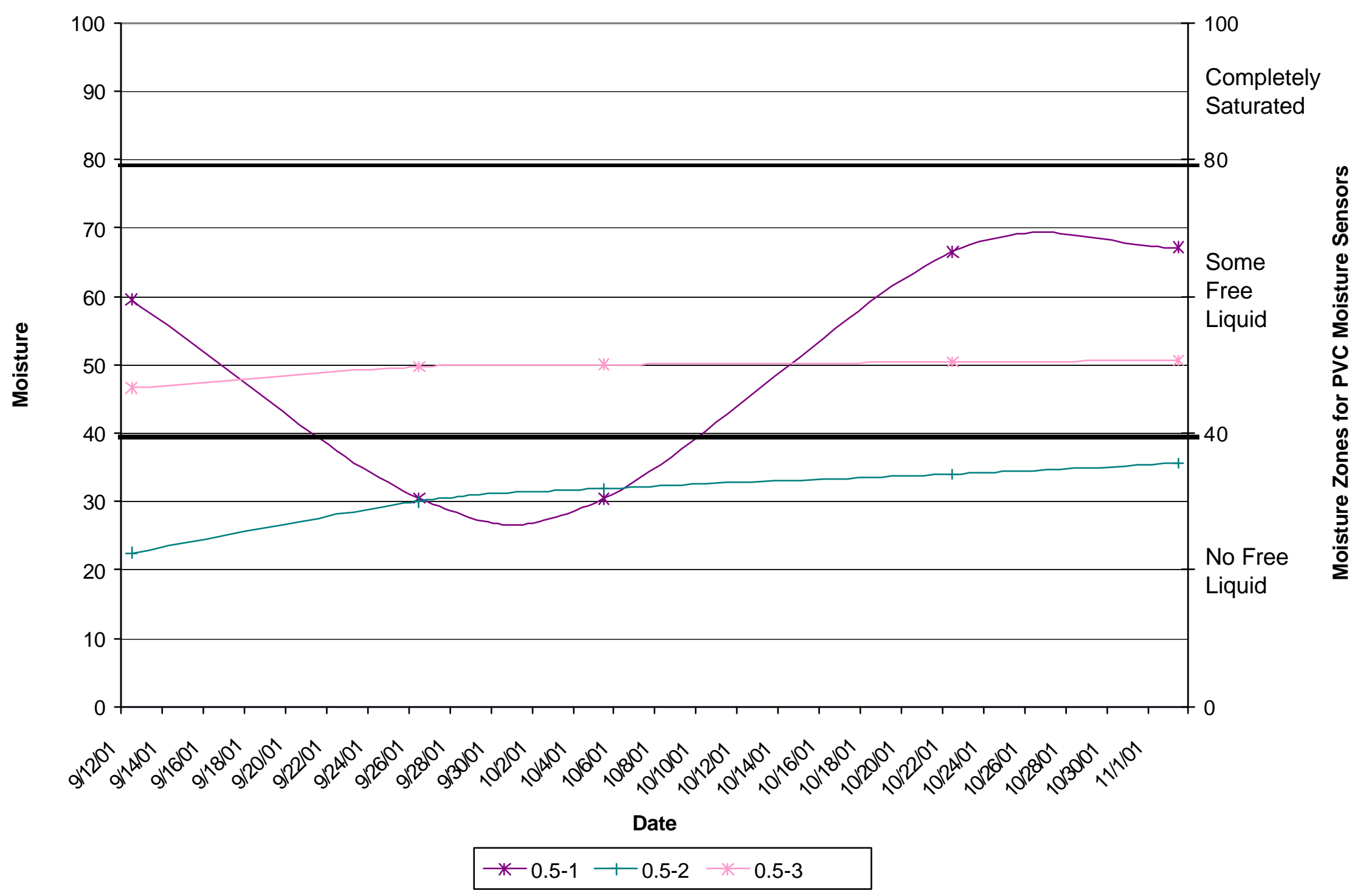




\section{Figure 27. Aerobic Cell Layer 1 Moisture Readings (PVC Moisture Sensors)}

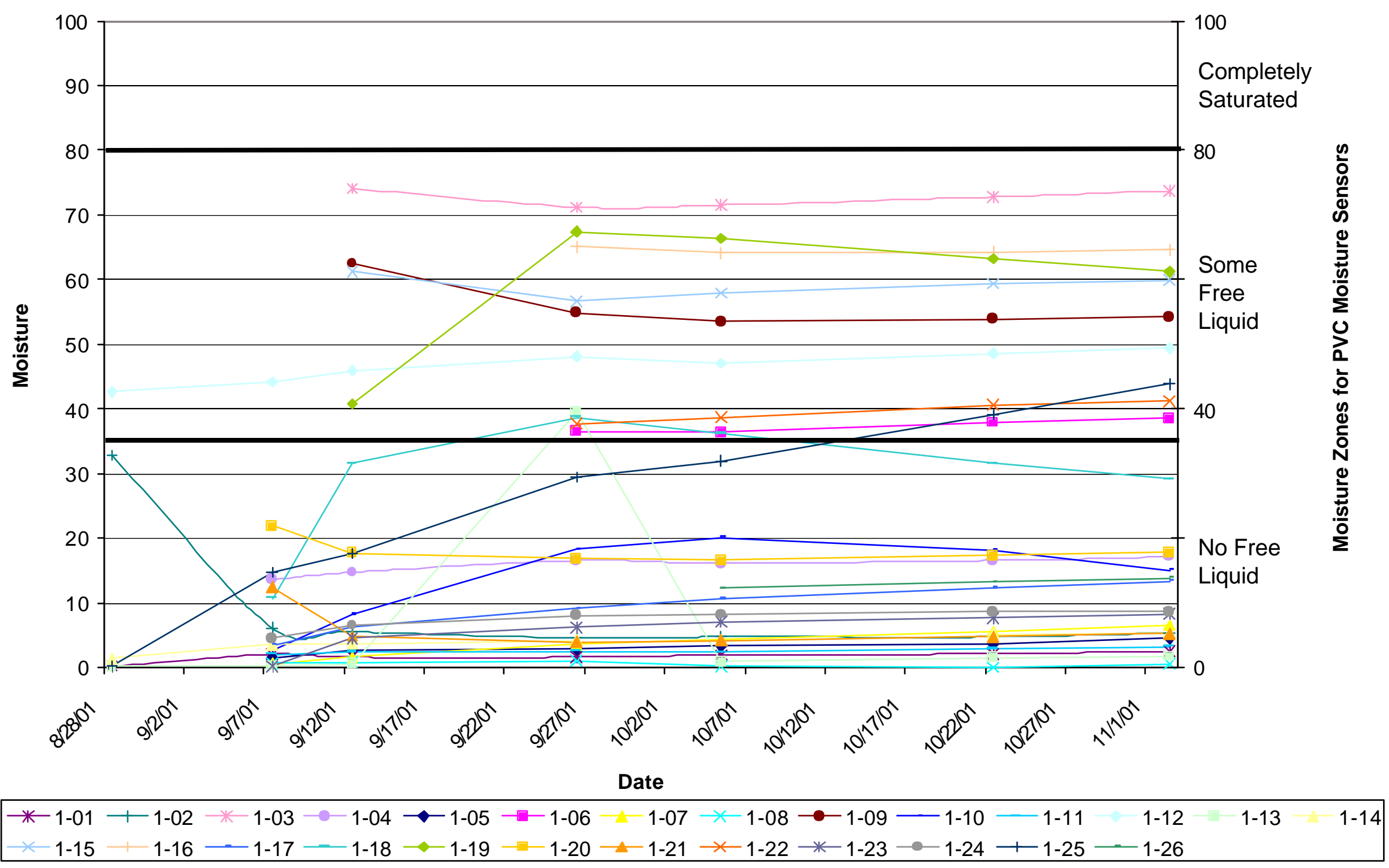


Figure 28. Aerobic Cell Layer 2 Moisture Readings (PVC Moisture Sensors)

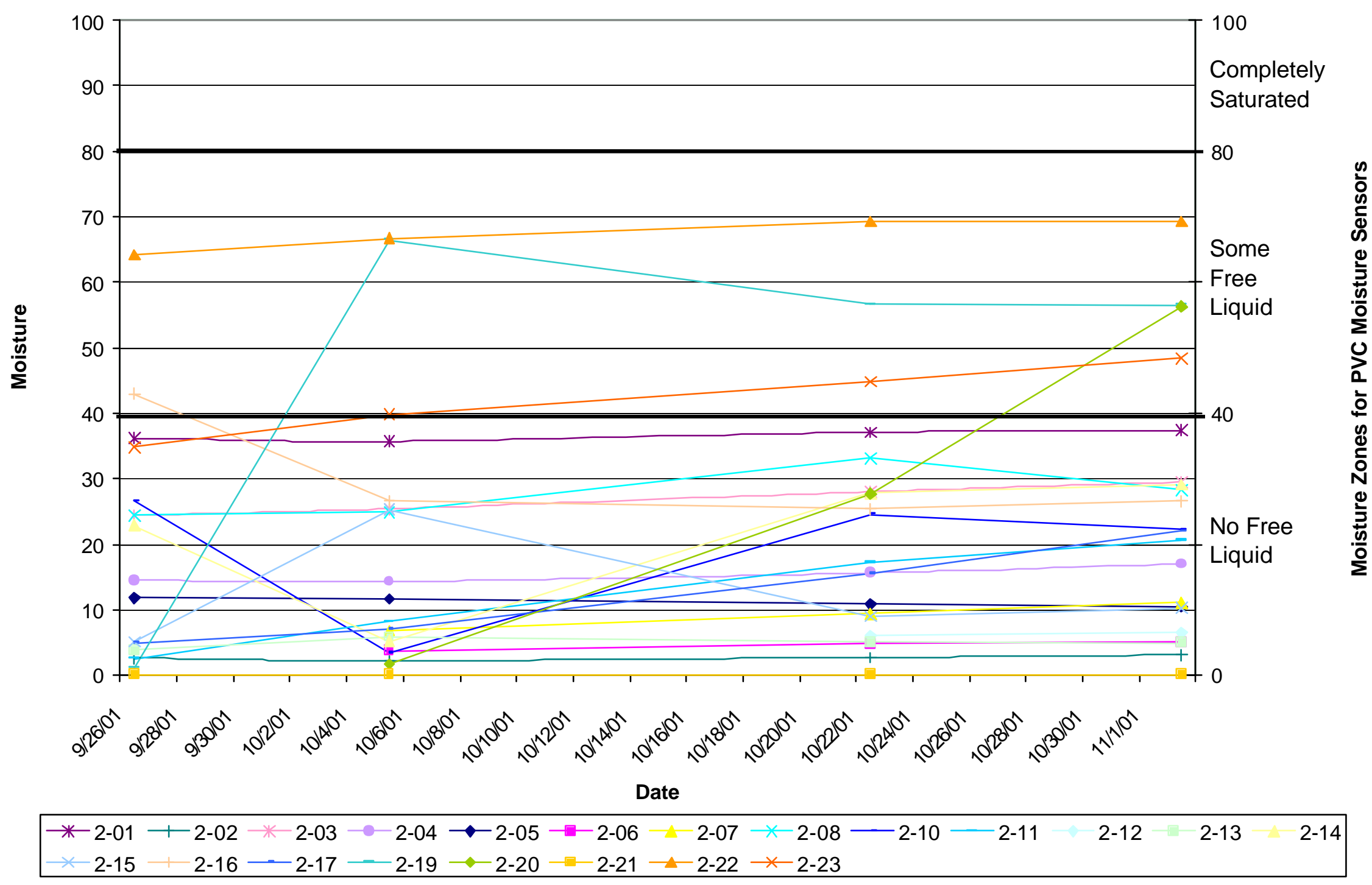


Figure 29. Southeast Quadrant Anaerobic Base Liner Tube Readings

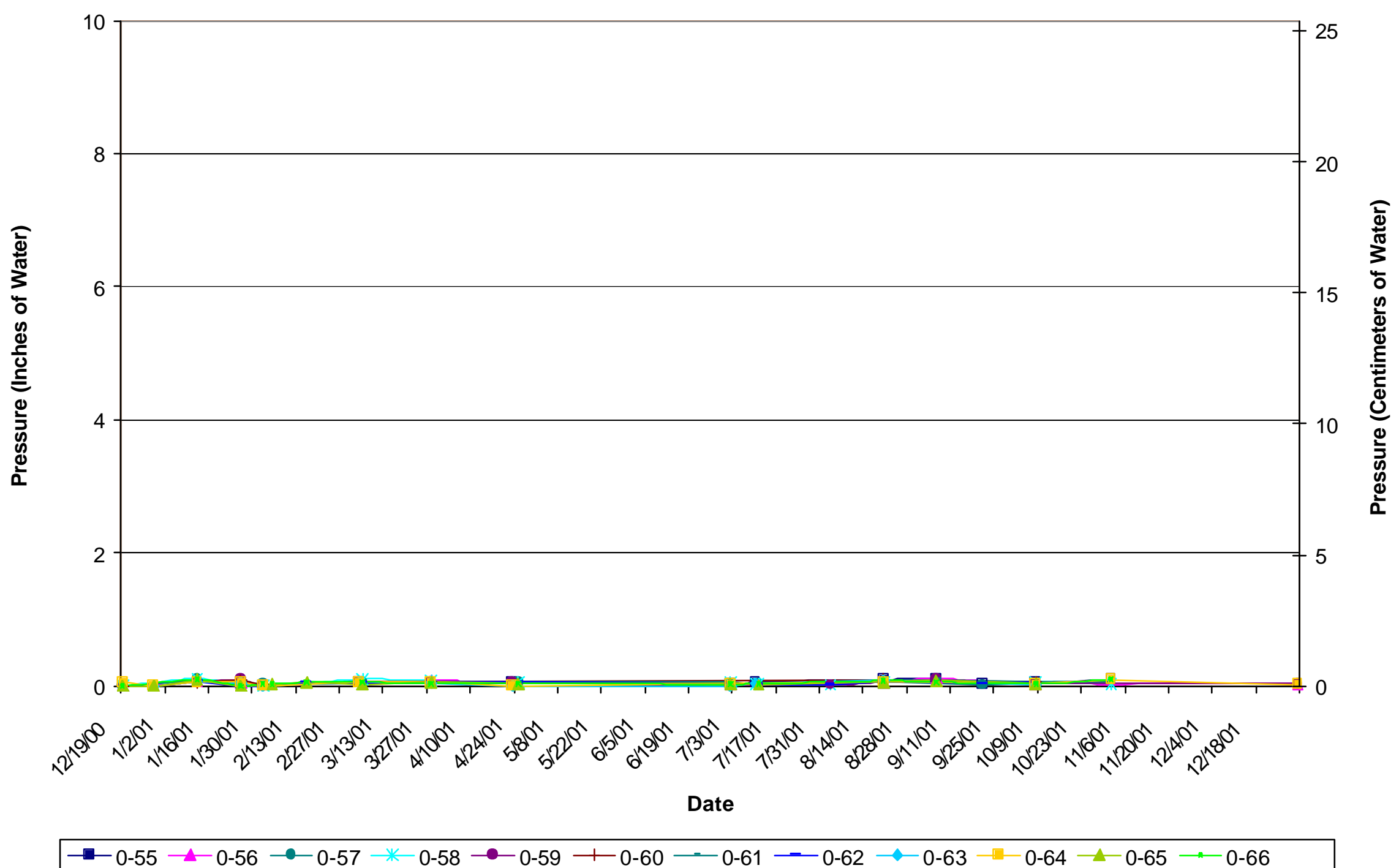




\section{Figure 30. Aerobic Cell Layer 0 Tube Readings for Pressure}

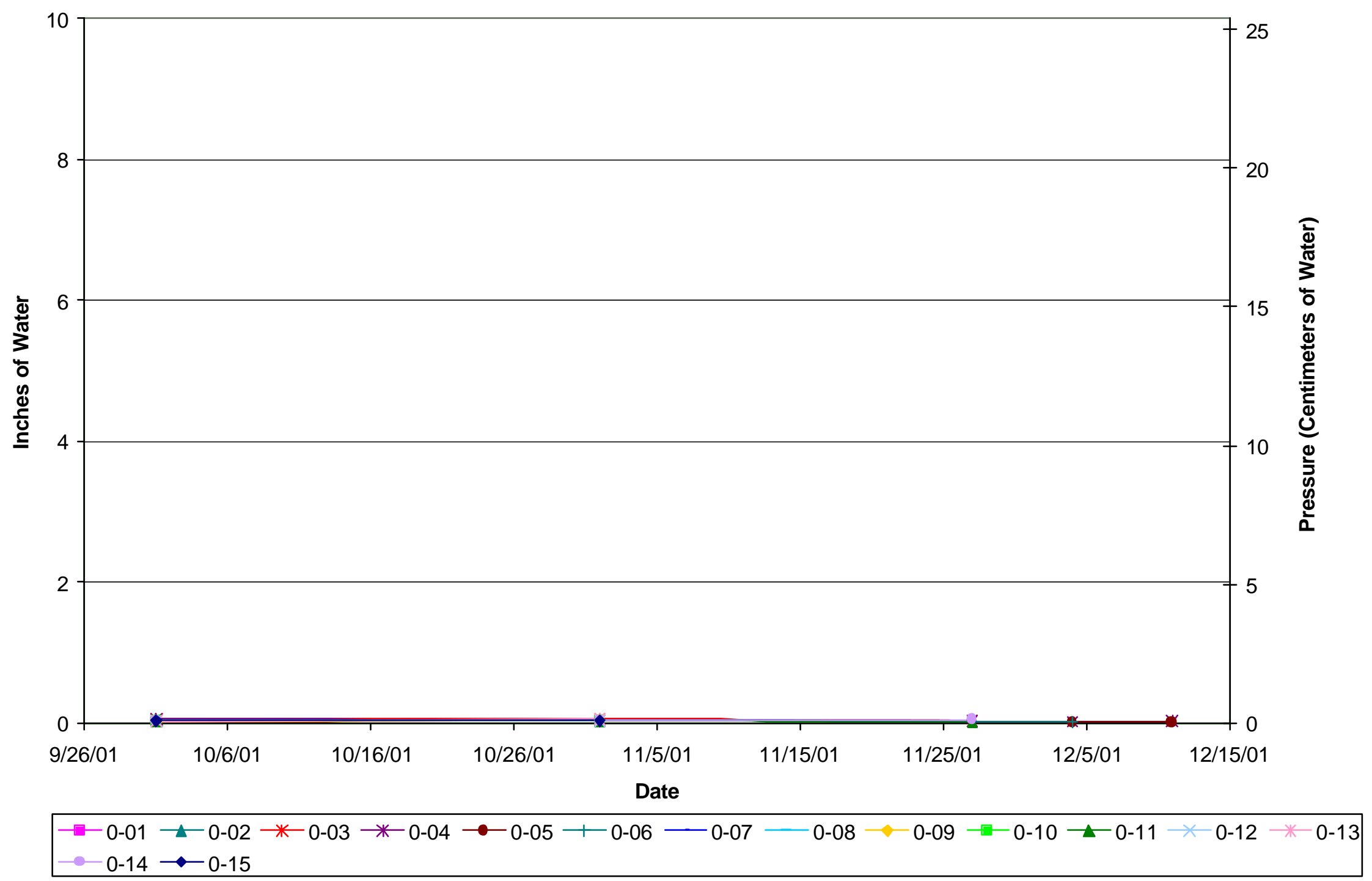




\section{Figure 31. Aerobic Cell Layer 1 Tube Readings for Pressure}

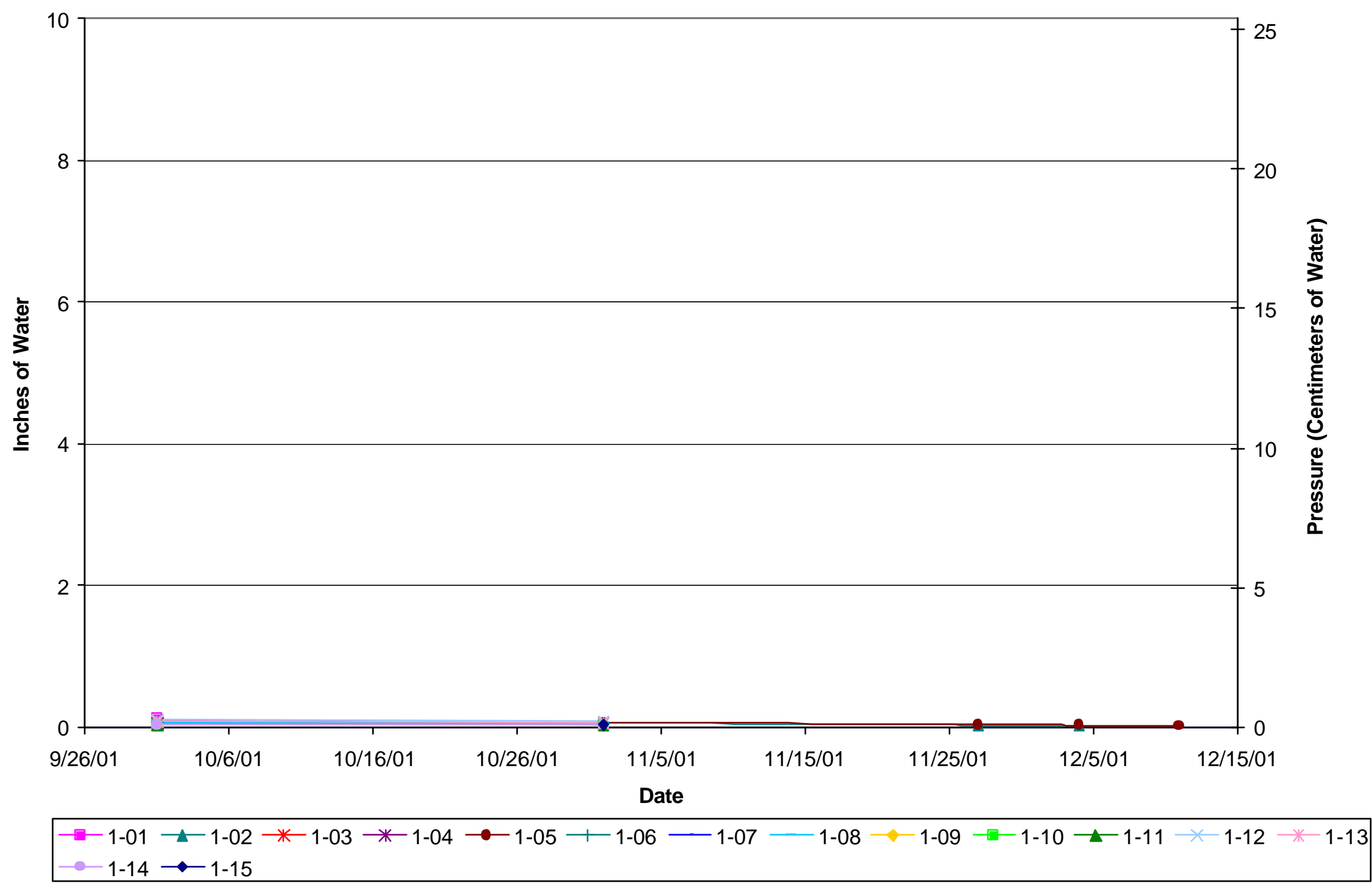




\section{Figure 32. Aerobic Cell Layer 2 Tube Readings for Pressure}

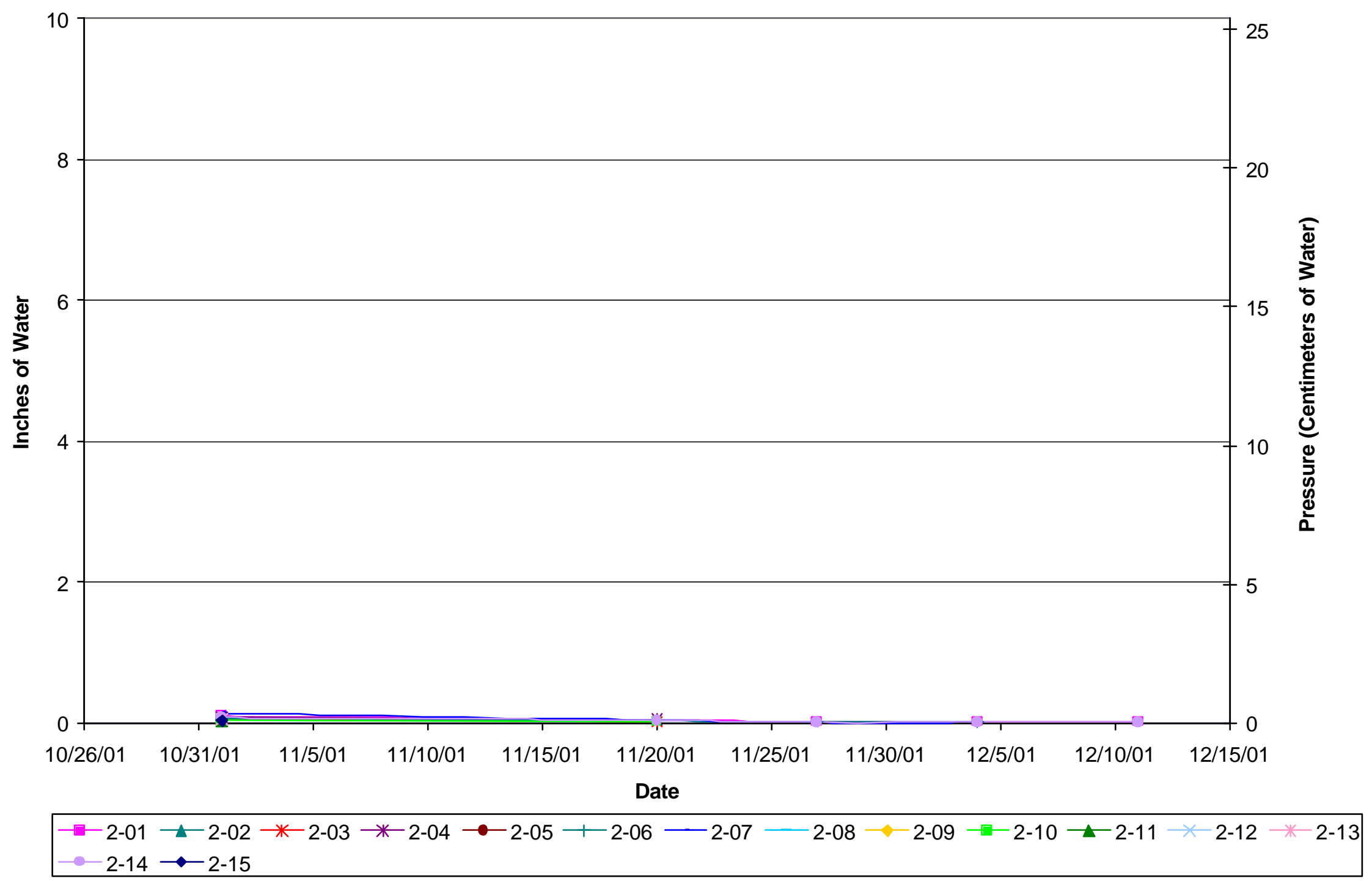


Table 13. Southeast Quadrant Anaerobic Base Liner Gas Compositions

\begin{tabular}{|c|c|c|c|c|c|c|c|c|c|c|c|c|c|c|c|c|c|c|c|c|}
\hline Sensor' & \multicolumn{4}{|c|}{$0-55$} & \multicolumn{4}{|c|}{$0-56$} & \multicolumn{4}{|c|}{$0-57$} & \multicolumn{4}{|c|}{$\frac{0-58}{0 / 3 / 20}$} & \multicolumn{4}{|c|}{$0-59$} \\
\hline $\begin{array}{l}\text { Date Installed: } \\
\text { Date Covered²: }\end{array}$ & & & $\begin{array}{l}30 / 00 \\
12 / 01\end{array}$ & & & & $\begin{array}{l}30 / 00 \\
29 / 00 \\
\end{array}$ & & & & $\begin{array}{l}30 / 00 \\
/ 29 / 00 \\
\end{array}$ & & & & $\begin{array}{l}30 / 00 \\
/ 29 / 00\end{array}$ & & & & $\begin{array}{l}130 / 00 \\
12 / 01 \\
\end{array}$ & \\
\hline Date Monitored & $\% \mathrm{CH}_{4}$ & $\% \mathrm{CO}_{2}$ & $\% \mathrm{O}_{2}$ & $\%$ Balance $^{3}$ & $\% \mathrm{CH}_{4}$ & $\% \mathrm{CO}_{2}$ & $\% \mathrm{O}_{2}$ & $\%$ Balance & $\% \mathrm{CH}_{4}$ & $\% \mathrm{CO}_{2}$ & $\% \mathrm{O}_{2}$ & $\%$ Balance & $\% \mathrm{CH}_{4}$ & $\% \mathrm{CO}_{2}$ & $\% \mathrm{O}_{2}$ & $\%$ Balance & $\% \mathrm{CH}_{4}$ & $\% \mathrm{CO}_{2}$ & $\% \mathrm{O}_{2}$ & $\%$ Balance \\
\hline $\begin{array}{c}5 / 30 / 01 \\
7 / 3 / 01 \\
7 / 10 / 01 \\
7 / 11 / 01 \\
8 / 3 / 01 \\
8 / 21 / 01 \\
9 / 6 / 01 \\
9 / 21 / 01 \\
12 / 31 / 01\end{array}$ & $\begin{array}{l}36.2 \\
42.4\end{array}$ & 46.8 & $\begin{array}{c}1 \\
0.2\end{array}$ & $\begin{array}{c}14.7 \\
5.3\end{array}$ & 29 & 58.9 & 0 & 12.9 & $\begin{array}{c}32 \\
28.3\end{array}$ & $\begin{array}{l}58.2 \\
48.5\end{array}$ & $\begin{array}{c}0 \\
3.2\end{array}$ & $\begin{array}{l}9.9 \\
20\end{array}$ & $\begin{array}{l}27.6 \\
20.5\end{array}$ & $\begin{array}{l}47.9 \\
44.1\end{array}$ & $\begin{array}{l}0 \\
0\end{array}$ & $\begin{array}{l}24.4 \\
35.7\end{array}$ & $\begin{array}{l}13.3 \\
32.4 \\
30.6 \\
\\
13.4\end{array}$ & $\begin{array}{l}30.6 \\
52.8 \\
53.5 \\
\\
36.6\end{array}$ & $\begin{array}{c}8.2 \\
0 \\
0\end{array}$ & $\begin{array}{c}48 \\
14.8 \\
8.1 \\
48.3\end{array}$ \\
\hline
\end{tabular}

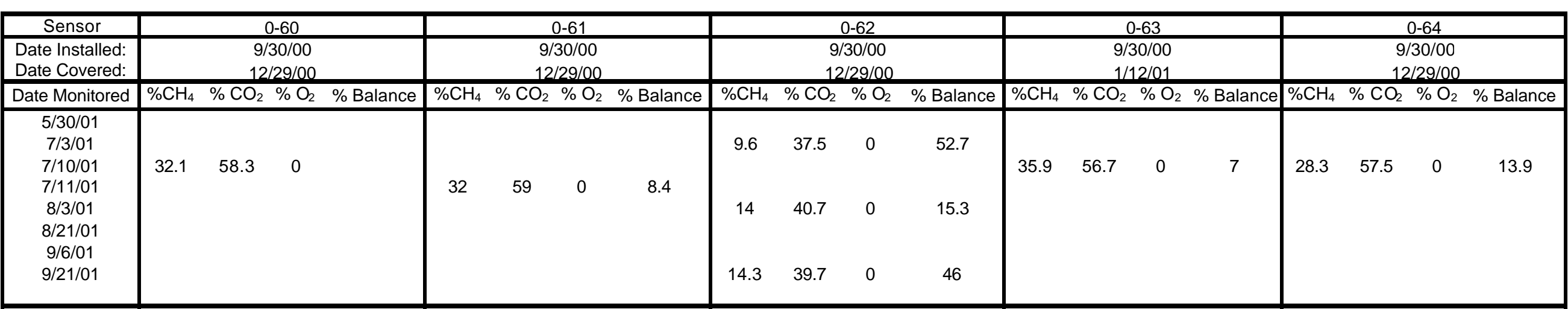

\begin{tabular}{|c|c|c|c|c|c|c|c|c|}
\hline Sensor & \multicolumn{4}{|c|}{$0-65$} & \multicolumn{4}{|c|}{$0-66$} \\
\hline Date Installed: & \multicolumn{4}{|c|}{$\begin{array}{c}9 / 30 / 00 \\
12 / 29 / 00\end{array}$} & \multicolumn{4}{|c|}{$\begin{array}{c}9 / 30 / 00 \\
12 / 29 / 00\end{array}$} \\
\hline Date Monitored & $\% \mathrm{CH}_{4}$ & $\% \mathrm{CO}_{2}$ & $\% \mathrm{O}_{2}$ & $\%$ Balance & $\mathrm{CH}_{4}$ & $\mathrm{CO}_{2}$ & $\mathrm{O}_{2}$ & Balance \\
\hline $\begin{array}{c}5 / 30 / 01 \\
7 / 3 / 01\end{array}$ & & & & & & & & \\
\hline $\begin{array}{l}7 / 10 / 01 \\
7 / 11 / 01\end{array}$ & 28.4 & 57.2 & 0 & 14.4 & & & & \\
\hline $\begin{array}{c}8 / 21 / 01 \\
9 / 6 / 01\end{array}$ & 33.4 & 56.5 & 0 & 10.5 & $\begin{array}{l}16.8 \\
19.9\end{array}$ & $\begin{array}{l}40.5 \\
40.7\end{array}$ & $\begin{array}{l}0 \\
0\end{array}$ & $\begin{array}{l}42.5 \\
39.4\end{array}$ \\
\hline
\end{tabular}

${ }^{1}$ Sensor nomenclature: Instrumentation layer \# the senor is located - Sensor \# on that layer

${ }^{2}$ Date covered refers to the date waste was placed over the sensor

${ }^{3}$ Balance is assumed to be nitrogen

*Gas Compositions measured by the GEM-500 by Landtec 
Table 14. Aerobic Cell Layer 0 Gas Compositions

\begin{tabular}{|c|c|c|c|c|c|c|c|c|c|c|c|c|c|c|c|c|c|c|c|c|}
\hline Sensor $^{1}$ & \multicolumn{4}{|c|}{$0-04$} & \multicolumn{4}{|c|}{$0-05$} & \multicolumn{4}{|c|}{$0-07$} & \multicolumn{4}{|c|}{$0-14$} & \multicolumn{4}{|c|}{$0-15$} \\
\hline Date: & $\mathrm{CH}_{4} \%$ & $\mathrm{CO}_{2} \%$ & $\mathrm{O}_{2} \%$ & $\%$ Balance $^{2}$ & $\mathrm{CH}_{4} \%$ & $\mathrm{CO}_{2} \%$ & $\mathrm{O}_{2} \%$ & Balance \% & $\mathrm{CH}_{4} \%$ & $\mathrm{CO}_{2} \%$ & $\mathrm{O}_{2} \%$ & Balance \% & $\mathrm{CH}_{4} \%$ & $\mathrm{CO}_{2} \%$ & $\mathrm{O}_{2} \%$ & Balance \% & $\mathrm{CH}_{4} \%$ & $\mathrm{CO}_{2} \%$ & $\mathrm{O}_{2} \%$ & Balance \% \\
\hline $8 / 20 / 01$ & & & & & & & & & & & & & 0 & 0.9 & $\begin{array}{l}920.5 \\
\end{array}$ & 78.7 & 1.6 & 40.7 & $7 \quad 1.3$ & 56.6 \\
\hline 10/2/01 & 1.8 & 23.3 & 4.3 & 70.4 & 2.3 & 29.9 & 0.9 & 66.8 & 4.4 & 38.3 & 5 & 51.6 & 3.6 & 32.5 & 0.6 & 63.3 & & & & \\
\hline $11 / 1 / 01$ & 4.3 & 23.9 & 0 & 71.8 & & & & & 4 & 26.4 & 0 & 69.6 & 1 & 14.7 & 3.8 & 80.1 & 2.6 & 29 & & 68.4 \\
\hline $11 / 20 / 01$ & 4.4 & 25.8 & 0.2 & 69.7 & 4.7 & 25.3 & 1.1 & 68.7 & & & & & & & & & & & & \\
\hline $12 / 4 / 01$ & 0.7 & 10.4 & 7.4 & 81.4 & 1.9 & 16.7 & 1.2 & 80 & & & & & & & & & & & & \\
\hline
\end{tabular}

'Sensor nomenclature: Instrumentation layer \# the senor is located - Sensor \# on that layer

${ }^{2}$ Balance is assumed to be nitrogen

*Gas Compositions measured by the GEM-500 by Landtec 
Table 15. Aerobic Cell Layer 1 Gas Compositions

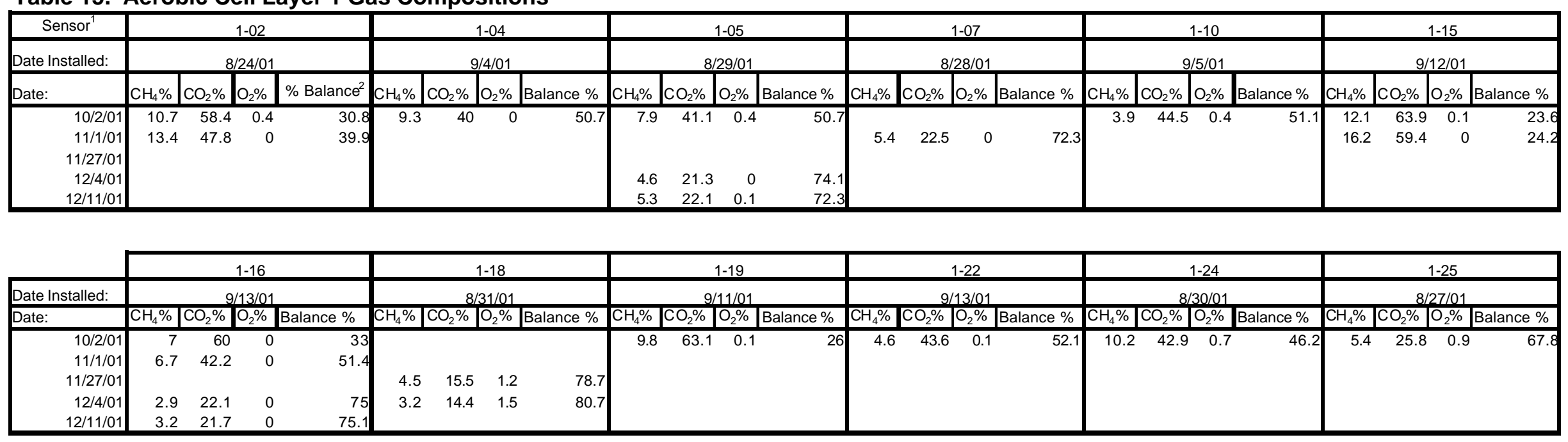

${ }^{1}$ Sensor nomenclature: Instrumentation layer \# the senor is located - Sensor \# on that layer ¿Balance is assumed to be nitrogen

*Gas Compositions measured by the GEM- 500 by Landtec 
Table 16. Aerobic Layer 2 Gas Compositions

\begin{tabular}{|c|c|c|c|c|c|c|c|c|c|c|c|c|c|c|c|c|c|c|c|c|}
\hline Sensor ${ }^{1}$ & \multicolumn{4}{|c|}{$2-01$} & \multicolumn{4}{|c|}{$2-05$} & \multicolumn{4}{|c|}{$2-06$} & \multicolumn{4}{|c|}{$2-07$} & \multicolumn{4}{|c|}{$2-11$} \\
\hline Date Installed: & \multicolumn{4}{|c|}{$9 / 24 / 01$} & \multicolumn{4}{|c|}{$9 / 17 / 01$} & \multicolumn{4}{|c|}{$9 / 19 / 01$} & \multicolumn{4}{|c|}{$9 / 19 / 01$} & \multicolumn{4}{|c|}{$9 / 24 / 01$} \\
\hline Date: & $\mathrm{CH}_{4} \%$ & $\mathrm{CO}_{2} \%$ & $\mathrm{O}_{2} \%$ & Balance $\%^{2}$ & $\mathrm{CH}_{4} \%$ & $\mathrm{CO}_{2} \%$ & $\mathrm{O}_{2} \%$ & Balance \% & $\mathrm{CH}_{4} \%$ & $\mathrm{CO}_{2} \%$ & $\mathrm{O}_{2} \%$ & Balance \% & $\mathrm{CH}_{4} \%$ & $\mathrm{CO}_{2} \%$ & $\mathrm{O}_{2} \%$ & Balance \% & $\mathrm{CH}_{4} \%$ & $\mathrm{CO}_{2} \%$ & $\mathrm{O}_{2} \%$ & Balance \% \\
\hline $10 / 2 / 01$ & 5.2 & 61.4 & 0.2 & 33.5 & 5.6 & 50.1 & 0 & 44.2 & 6.8 & 37.2 & 0.6 & 55.1 & 5.5 & 43 & 2.2 & 49.2 & & & & \\
\hline $11 / 1 / 01$ & & & & & 10.8 & 48.6 & 0 & 40.7 & & & & & & & & & 8.2 & 52.4 & 0 & 39.6 \\
\hline $11 / 27 / 01$ & 8.3 & 34.6 & 0.1 & 56.7 & & & & & 4.6 & 27.9 & 0.2 & 67.3 & 4 & 22.5 & 0.2 & 73.2 & & & & \\
\hline $12 / 4 / 01$ & 7.3 & 30 & 0 & 62.7 & & & & & 4.3 & 22.2 & 0.1 & 73.4 & 2.8 & 20.9 & 0.1 & 76.2 & & & & \\
\hline $12 / 11 / 01$ & 6.3 & 26.6 & 0 & 67.1 & & & & & & & & & & & & & & & & \\
\hline
\end{tabular}

\begin{tabular}{|c|c|c|c|c|c|c|c|c|}
\hline Sensor & \multicolumn{4}{|c|}{$2-13$} & \multicolumn{4}{|c|}{$2-14$} \\
\hline Date Installed: & \multicolumn{4}{|c|}{ 9/19/01 } & \multicolumn{4}{|c|}{$9 / 17 / 01$} \\
\hline Date: & $\mathrm{CH}_{4} \%$ & $\mathrm{CO}_{2} \%$ & $\mathrm{O}_{2} \%$ & Balance \% & $\mathrm{CH}_{4} \%$ & $\mathrm{CO}_{2} \%$ & $\mathrm{O}_{2} \%$ & Balance \% \\
\hline $10 / 2 / 01$ & & & & & 4.6 & 59.2 & 0.5 & 35.5 \\
\hline $11 / 1 / 01$ & 13 & 45.3 & 0 & 41.6 & & & & \\
\hline $11 / 27 / 01$ & & & & & 9.7 & 38 & 0.3 & 51 \\
\hline $12 / 4 / 01$ & & & & & 5.2 & 20.9 & 0.1 & 76.2 \\
\hline $12 / 11 / 01$ & & & & & 6.7 & 26.5 & 0.2 & 66.6 \\
\hline
\end{tabular}

Sensor nomenclature: Instrumentation layer \# the senor is located - Sensor \# on that layer

${ }^{2}$ Balance is assumed to be nitrogen

*Gas Compositions measured by the GEM- 500 by Landtec 


\section{Figure 33. Pressure Transducer and Adjacent Tube Pressure Readings}

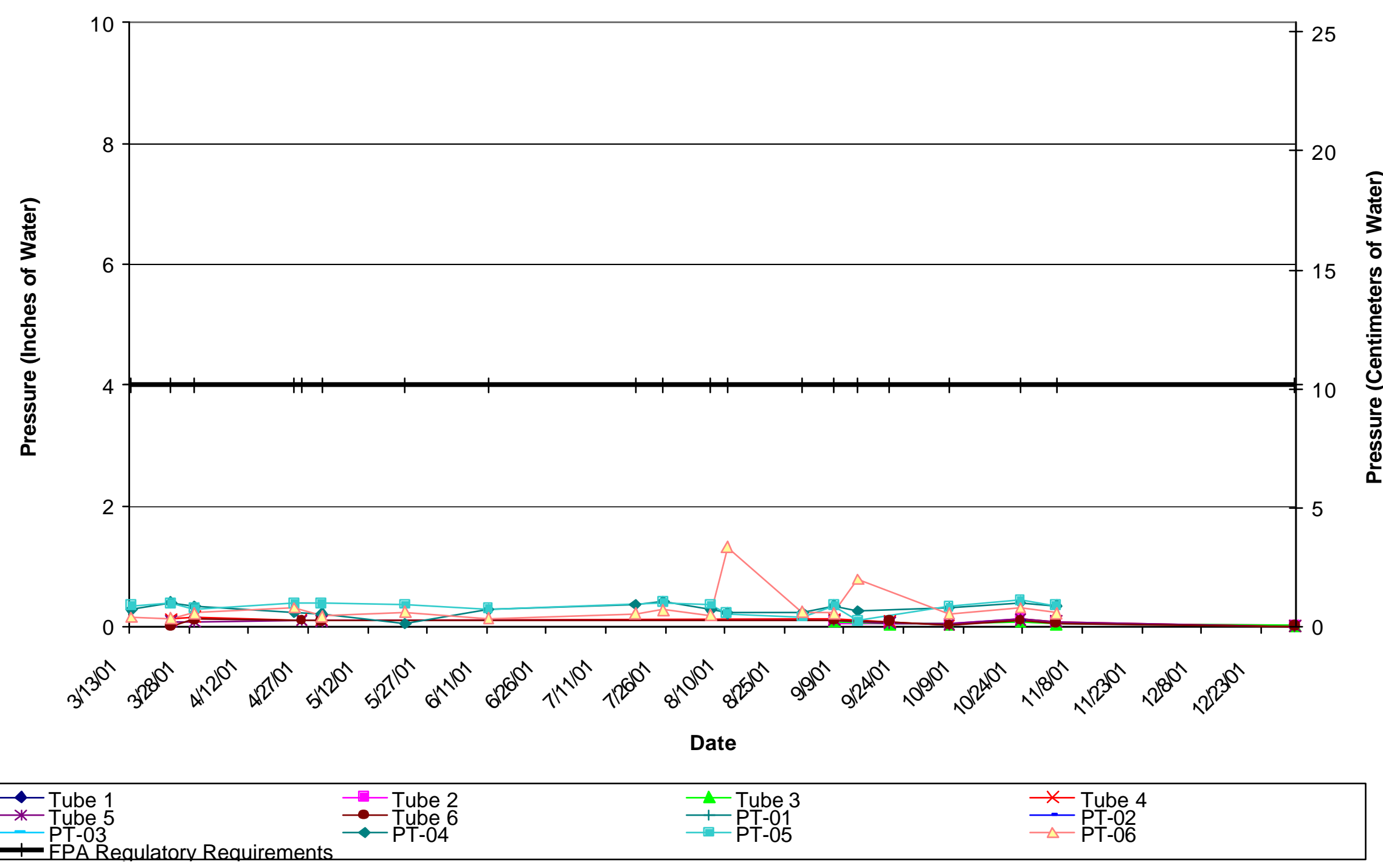


Figure 34. Trench Liquid Level Tube Pressure Readings

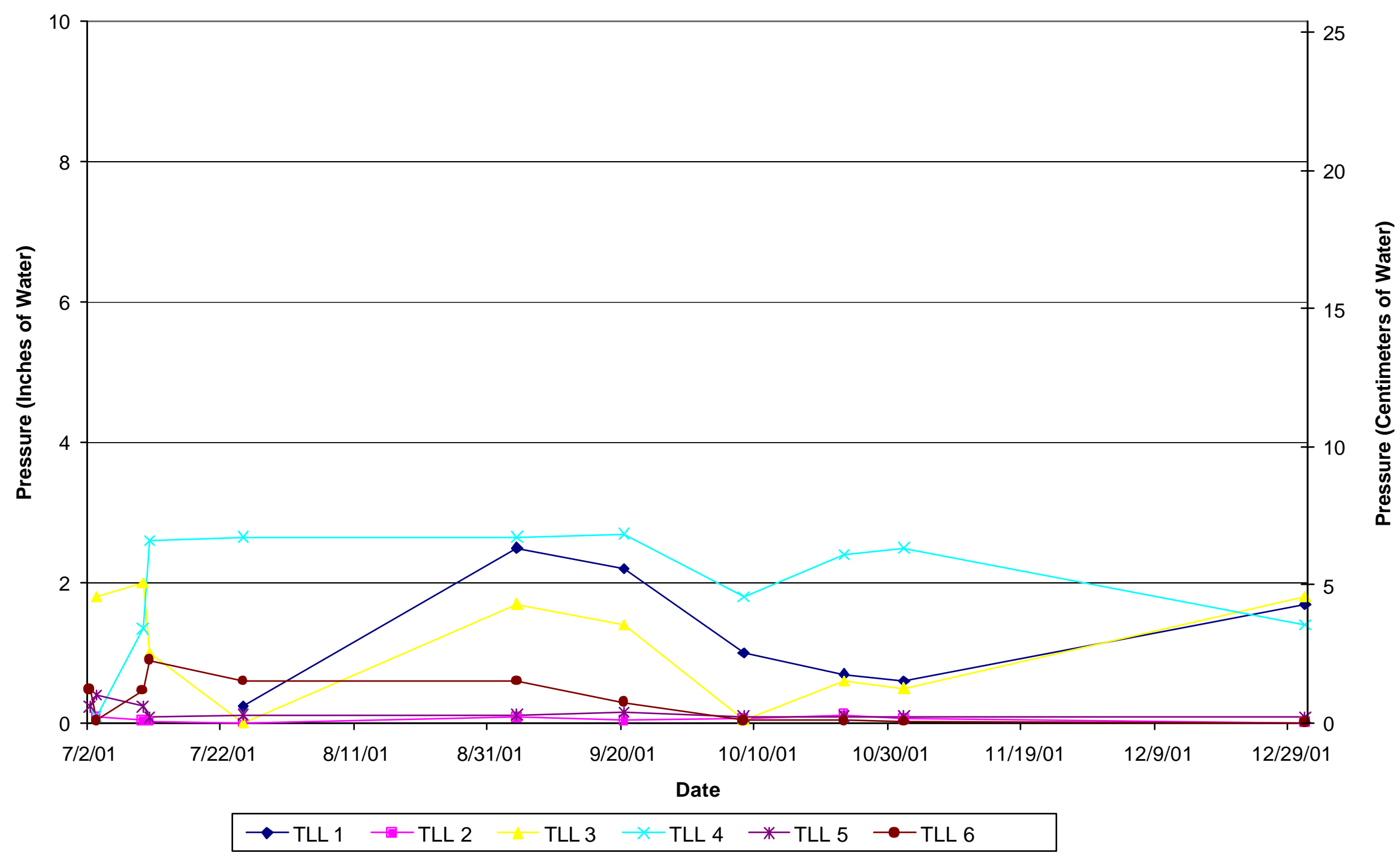

